\title{
Improved synthesis and comparative analysis of the tool properties of new and existing D-ring modified $(S)$-blebbistatin analogs
}

Sigrid Verhasselt, Bart I. Roman*, Marc E. Bracke, Christian V. Stevens*

SynBioC Research Group, Department of Sustainable Organic Chemistry and Technology, Campus Coupure, Ghent University, Coupure Links 653, 9000 Ghent, Belgium.

Laboratory of Experimental Cancer Research, Department of Radiation Oncology and Experimental Cancer Research, Ghent University, De Pintelaan 185, 9000 Ghent, Belgium.

*Corresponding author (bart1.roman@ugent.be, chris.stevens@ugent.be)

\begin{abstract}
S)$-blebbistatin is a widely used research tool to study myosin II, an important regulator of many motility based diseases. Its potency is too low to be of clinical relevance, but identification of analogs with enhanced potency could deliver leads for targeted pharmacotherapeutics. This, however, requires a profound insight into the structure-activity relationship of the $(S)$-blebbistatin scaffold. Therefore, new D-ring modified $(S)$-blebbistatin derivatives were prepared to extend the existing small library of analogs. These molecules were obtained via an improved synthesis pathway and their myosin II inhibitory properties were evaluated in vitro. Finally, all new and known D-ring modified $(S)$-blebbistatin analogs were compared and the most potent ones underwent a screening of their physicochemical properties.
\end{abstract}

Keywords blebbistatin, myosin II, photostability, solubility, cell membrane permeability

Abbreviations 2-mTHF (2-methyltetrahydrofuran); A-B (apical-to-basolateral); B-A (basolateral-to-apical); CV (column volume); DMAP (4-dimethylaminopyridine); DMEM (Dulbecco's modified Eagle medium); EGTA (ethylene glycol-bis( $\beta$-aminoethyl ether)$N, N, N^{\prime}, N^{\prime}$-tetraacetic acid); GFP (green fluorescent protein); HBSS (Hank's balanced salt solution); HEPES (4-(2-hydroxyethyl)-1-piperazineethanesulfonic acid); MOE (molecular operating environment); N.D. (not determined); $\mathrm{P}_{\mathrm{app}}$ (apparent permeability); PBS (phosphate-buffered saline); s.d. (standard deviation); $t_{1 / 2}$ (photodegradation half-life); TBAB (tetra- $n$-butylammonium bromide) 


\section{Introduction}

Myosins are actin-based molecular motors of the cell that convert the energy released by ATP hydrolysis into force and movement in an ATPase cycle [1]. Myosin II is part of the complex cellular processes driving cell division and cell movement. In recent years, interest in the role of myosin II in aberrant cellular function has strongly grown [2]. It has been identified as an important regulator in motility based diseases, e.g. viral infections [3-6], bacterial infections [7] and invasion in malignant disease [8-14]. The central role of myosin II in these diseases was revealed with the aid of the small-molecule research tool $(S)$-blebbistatin $(S)-\mathbf{1}$. This molecule is the best known probe for myosin II: it is a micromolar, cell membrane permeable, uncompetitive inhibitor of the protein's ATPase activity [15]. (S)-blebbistatin (S)-1 is an important research tool, but it carries a number of physicochemical deficiencies (e.g. photosensitivity upon blue light irradiation, low water solubility and ensuing interference of precipitates in read-outs) and improved analogs have been proposed in this context [16-19]. Novel myosin II inhibitors with significantly enhanced potency could also have the potential to serve as leads for targeted pharmacotherapeutics. Thus, new (S)-blebbistatin derivatives are necessary to provide supplemental information to the hitherto established structure-activity relationships [16-21].

Analysis of the co-crystal structure of $(S)$-blebbistatin $(S)$-1 bound to the metastable state of Dictyostelium discoideum myosin II (PDB: 1YV3) [22] indicated that space for extra (hydrophobic) substituents is present in the binding pocket surrounding ring $\mathrm{D}$, in particular near the 3'- and 4'-positions (Figure 1). We therefore investigated the tolerance of: (i) substituents of varying size in the 3'-position, ranging from allyloxy in analog $(S)$-2 to diallylamino in compound (S)-7, (ii) ring fusion at the $3^{\prime}, 4^{\prime}$-position, with a conformationally restrained monofunctionalized 3'-amino group in indoline $(S)-8$, a lipophilic naphthyl group incorporated in structure $(S)-\mathbf{9}$ and a more polar indole in analog $(S)$-10 and (iii) functional groups of varying size in the 4'-position, i.e. hydroxy, allyloxy and benzyloxy (derivatives (S)-11-13) (Figure 2). 

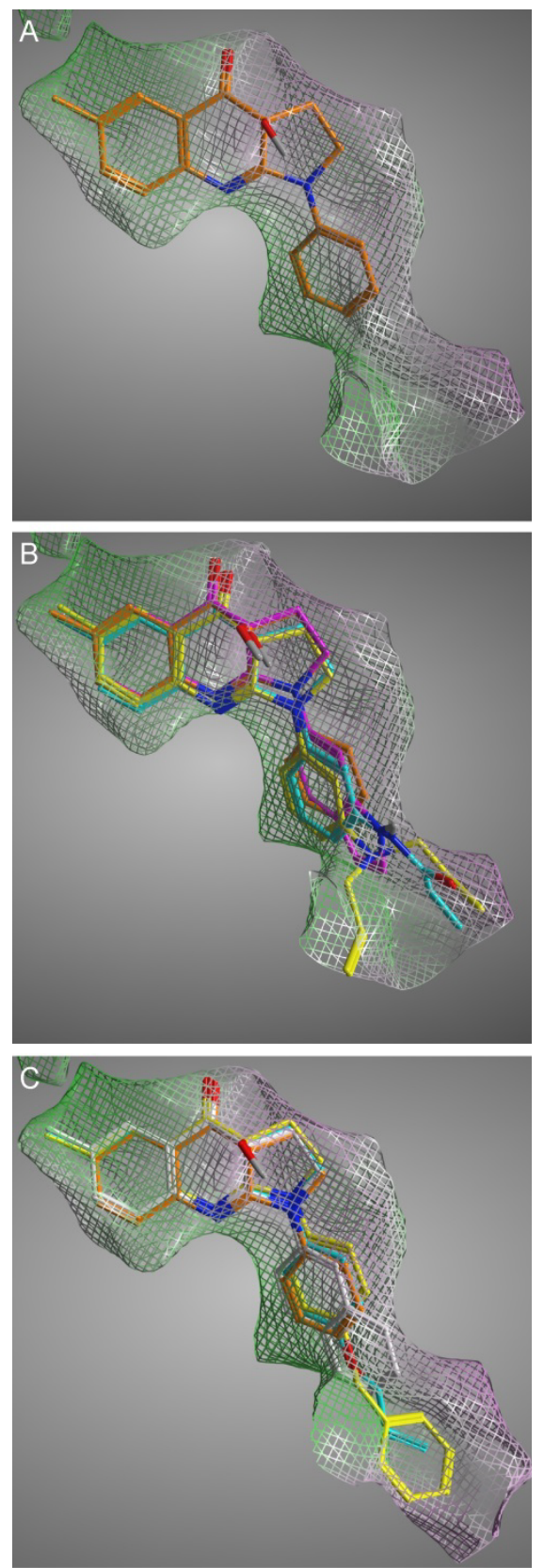

Figure 1. (A) Binding mode of (S)-blebbistatin $(S)$-1 (orange) with Dictyostelium discoideum myosin II (PDB structure: 1YV3) [22]. (B) Predicted binding poses of molecules (S)-5 (cyan), $(S)$-7 (yellow) and $(S)$-10 (fuchsia). (C) Predicted binding poses of compounds $(S)$-9 (white), $(S)-12$ (cyan) and (S)-13 (yellow). Interaction surfaces (onset of Van der Waals clash) are shown: pink indicates polar areas on the receptor surface, green indicates greasy areas. 
Previous work

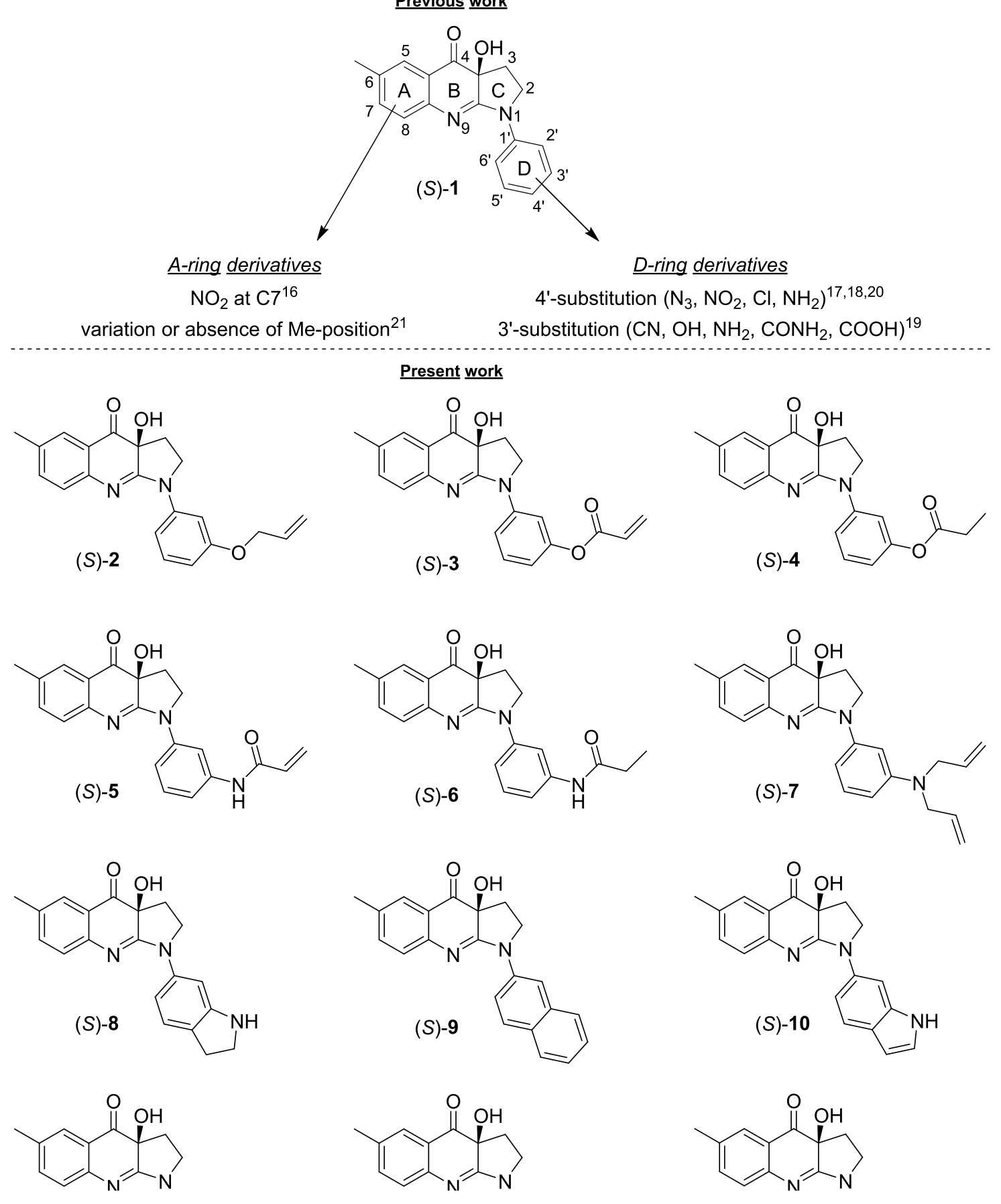

Figure 2. Overview of the state of the art and present work regarding structure-activity relationships on the blebbistatin scaffold. Top: Overview of existing A-ring and D-ring modified (S)-blebbistatin derivatives [16-21]. Bottom: Overview of newly synthesized $(S)$ blebbistatin derivatives $(S)$-2-13 with a modified D-ring. 


\section{Results and discussion}

\subsection{Chemistry}

The synthesis of $(S)$-3'-allyloxyblebbistatin $(S)$-2, $(S)$-3'-diallylaminoblebbistatin $(S)$-7, $(S)$ 3'-hydroxyblebbistatin $(S)$-17 and $(S)$-3'-aminoblebbistatin $(S)$-18 has been reported previously by us (Scheme 1) [19]. In that sequence, amidines 14a-c underwent intramolecular cyclization upon treatment with LiHMDS, resulting in isolation of quinolones 15a-c. $\alpha-$ Hydroxy ketones $(S)-\mathbf{1},(S)$-2 and $(S)$-7 were synthesized via deprotonation of quinolones 15a-c using LiHMDS and Davis' oxaziridine methodology. Allyl deprotection of enantiopure (S)-3'-allyloxyblebbistatin (S)-2 and (S)-3'-diallylaminoblebbistatin (S)-7 afforded (S)-3'hydroxyblebbistatin $(S)-\mathbf{1 7}$ and $(S)-3$ '-aminoblebbistatin $(S)$-18, respectively.

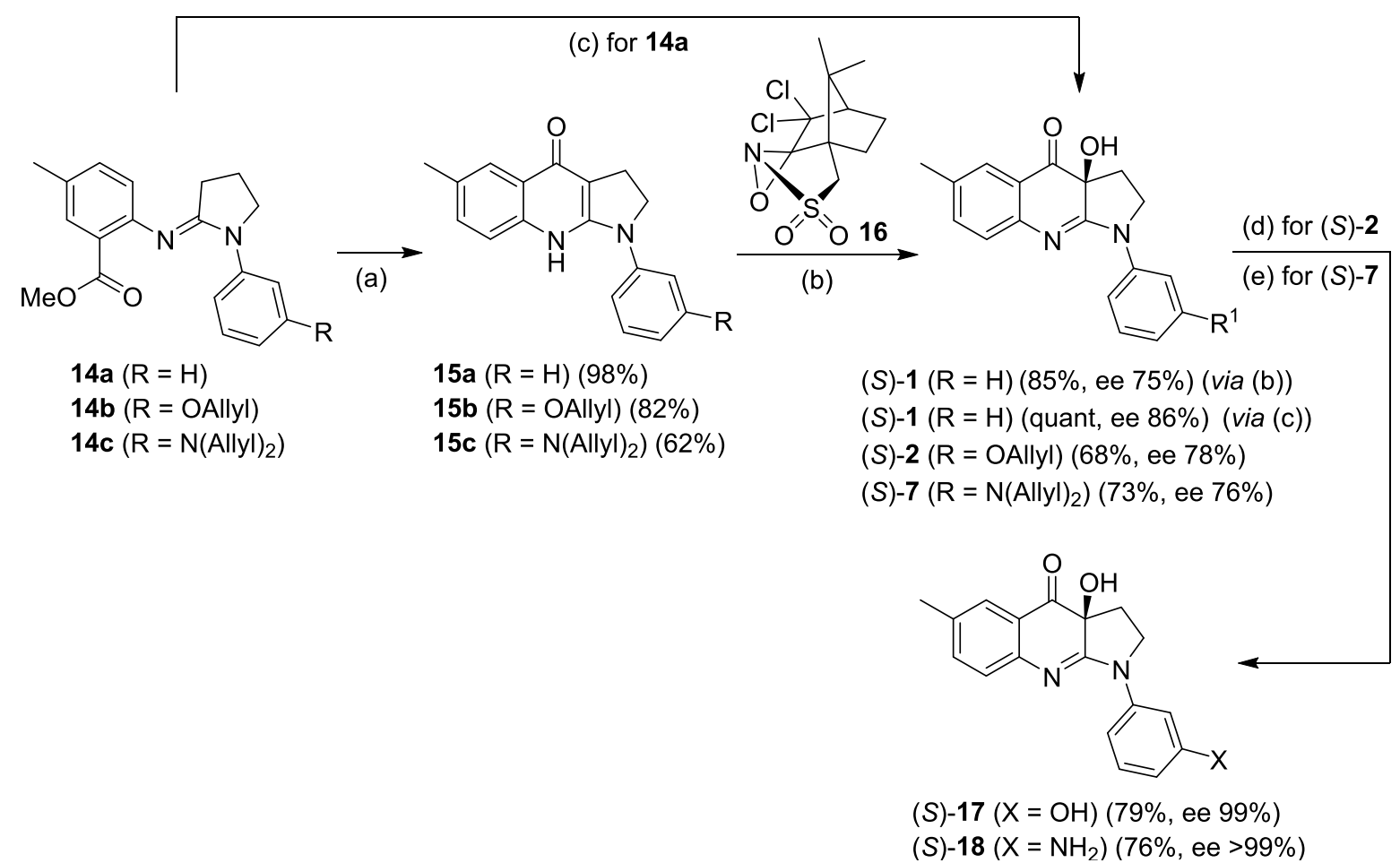

Scheme 1. Synthesis of (S)-3'-allyloxyblebbistatin $(S)$-2, $(S)$-3'-diallylaminoblebbistatin $(S)$ 7, $(S)$-3'-hydroxyblebbistatin (S)-17 and (S)-3'-aminoblebbistatin $(S)$-18, as previously reported by Verhasselt et al. [19]. Reagents and conditions: (a) LiHMDS, THF, $0{ }^{\circ} \mathrm{C}, 1 \mathrm{~h}$; (b) (1) LiHMDS, THF, $-78{ }^{\circ} \mathrm{C}, 30 \mathrm{~min},(2) \mathbf{1 6}$, THF, $-15^{\circ} \mathrm{C}, 16 \mathrm{~h}$; (c) (1) LiHMDS, THF, $0{ }^{\circ} \mathrm{C}$, $1.5 \mathrm{~h}$, (2) 16, THF, $-15^{\circ} \mathrm{C}, 16 \mathrm{~h}$; (d) $\mathrm{Pd}\left(\mathrm{PPh}_{3}\right)_{4}, \mathrm{~K}_{2} \mathrm{CO}_{3}, \mathrm{MeOH}, 50{ }^{\circ} \mathrm{C}, 1 \mathrm{~h}$; (e) $N, N^{\prime}-$ dimethylbarbituric acid, $\mathrm{Pd}\left(\mathrm{PPh}_{3}\right)_{4}, \mathrm{CH}_{2} \mathrm{Cl}_{2}$, reflux, $1 \mathrm{~h}$. 
We have meanwhile developed a more convenient one-pot synthesis of $\alpha$-hydroxy ketones from amidines, without isolation of the intermediate quinolones (Scheme 1). In this way, amidine 14a was converted to $\alpha$-hydroxy ketone $(S)$-1 (step (c)) in higher yield (quant vs $83 \%$ ) and enantiomeric excess (86\% vs $75 \%$ ) than the two-pot procedure. This is an important enhancement of the synthesis of the blebbistatin scaffold.

(S)-3'-hydroxyblebbistatin $(S)$-17 and $(S)$-3'-aminoblebbistatin $(S)$-18 were used as starting points for the synthesis of derivatives $(S)-\mathbf{3},(S)-\mathbf{4},(S)-\mathbf{5}$ and $(S)-\mathbf{6}$ (Scheme 2). Selective esterification of phenol (S)-17 (step (a)) was obtained by using stoichiometric amounts of $\mathrm{Cs}_{2} \mathrm{CO}_{3}$ and a small excess of acryloyl chloride or propionyl chloride, resulting in (S)-3'acryloxyblebbistatin $(S)-3$ (61\%, ee >99\%) and $(S)$-3'-propionyloxyblebbistatin $(S)-4$ (99\%, ee 99\%), respectively. (S)-3'-acrylamidoblebbistatin $(S)-5$ (73\%, ee 99\%) and (S)-3'propionylamidoblebbistatin $(S)-6(91 \%$, ee $>99 \%)$ were prepared through a procedure adopted from Jahani et al. [23]. Selective monoamidation of aniline (S)-18 (step (b)) was achieved using stoichiometric amounts of acrylic [24] or propionic anhydride and guanidine hydrochloride. In both sequences, reactions conducted with acryloyl reagents required chromatographic purification, thereby lowering the isolated yields.

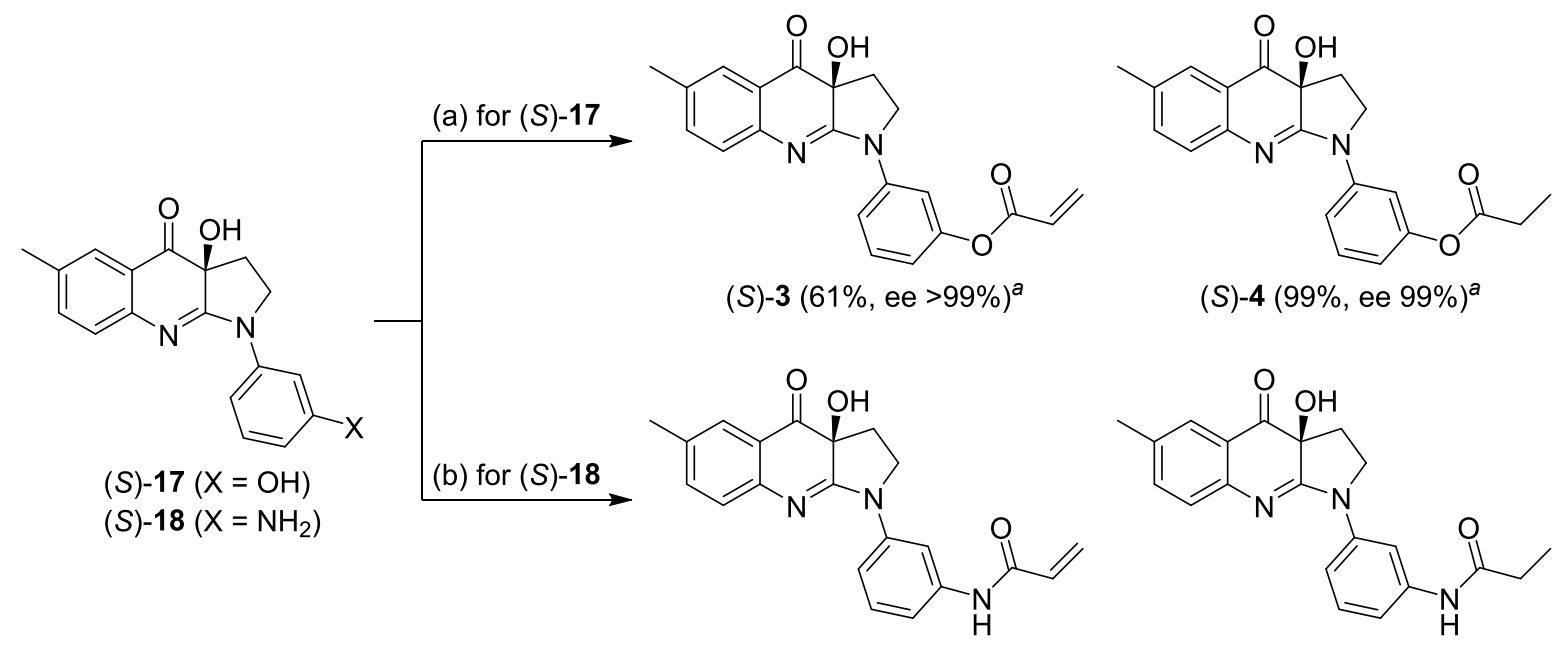

Scheme 2. Synthesis of $(S)$-3'-acryloxyblebbistatin $(S)$-3, $(S)$-3'-propionyloxyblebbistatin $(S)$ 4, (S)-3'-acrylamidoblebbistatin (S)-5 and (S)-3'-propionylamidoblebbistatin (S)-6 via selective esterification of phenol $(S)-\mathbf{1 7}$ and selective mono-amidation of aniline $(S)-\mathbf{1 8}$, respectively. Reagents and conditions: (a) $\mathrm{Cs}_{2} \mathrm{CO}_{3}$, DMAP, acryloyl chloride (for $(S)$-3) or propionyl chloride (for (S)-4), $\mathrm{CH}_{3} \mathrm{CN}, \mathrm{rt}, 30 \mathrm{~min}$; (b) guanidine hydrochloride, acrylic anhydride (for $(S)$-5) or propionic anhydride (for $(S)-6)$, EtOH, $40{ }^{\circ} \mathrm{C}, 30 \mathrm{~min}$. ${ }^{a}$ Determination of ee via chiral HPLC analysis was performed after synthesis of analytical amounts of the $(R)$-enantiomers (i.e. $(R)-3-6)$ from $(R)$-17-18. 
The synthesis of $(S)$-benzo[c']blebbistatin $(S)$-9 was performed using 2-bromonaphthalene (19) as starting material (Scheme 3). CuI catalyzed $\mathrm{N}$-arylation of 2-pyrrolidinone (20) with tris(3,5-dimethyl-1 $H$-pyrazol-1-yl)methane $[25,26]$ and $\mathrm{K}_{2} \mathrm{CO}_{3}[27,28]$ as a ligand and base, respectively, only gave trace amounts of pyrrolidinone 21a. In contrast, use of $N, N$ '-dimethylethylenediamine and $\mathrm{K}_{2} \mathrm{CO}_{3}$ provided pyrrolidinone 21a in excellent yield (step (a), 98\%). Amidine 14d was obtained in moderate yield (step (b), 48\%), which was completely converted to $\alpha$-hydroxy ketone $(S)-9$ through our improved two-step one-pot procedure (step (c), 50\%, ee 72\%). Isolation of compound (S)-9 by acid-base extraction proved more difficult than for $(S)-\mathbf{1}$ due to its more hydrophobic nature, resulting in a moderate yield. Recrystallization from $\mathrm{CH}_{3} \mathrm{CN}$ afforded enantiopure $(S)$ benzo[c']blebbistatin $(S)-9$ (ee $>99 \%)$.

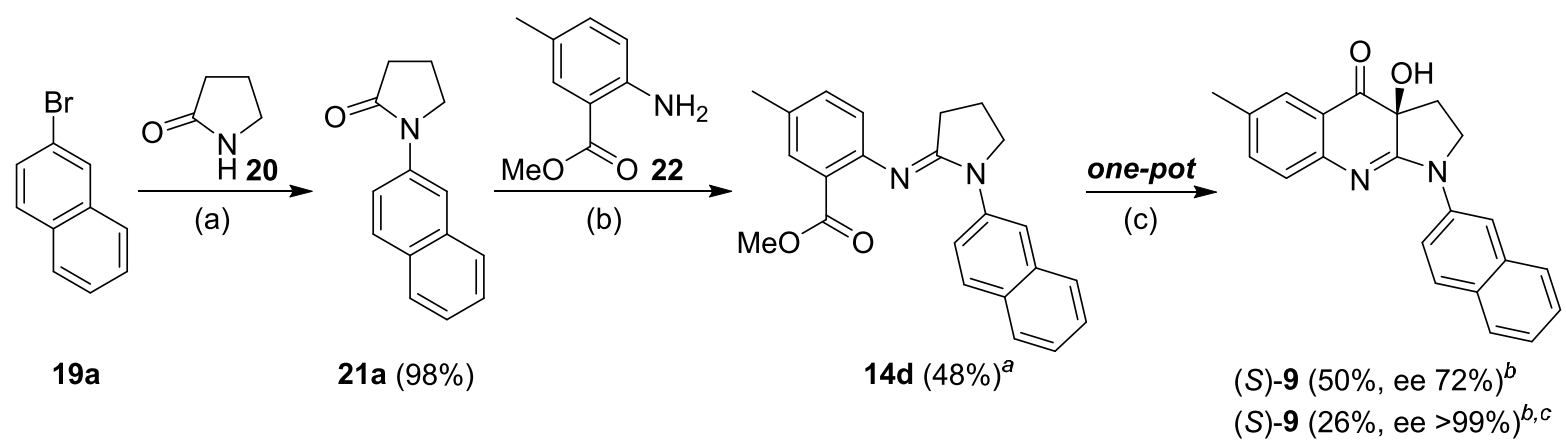

Scheme 3. Synthesis of (S)-benzo[c']blebbistatin (S)-9. Reagents and conditions: (a) CuI, $N$,N'-dimethylethylenediamine, 20, $\mathrm{K}_{2} \mathrm{CO}_{3}$, 1,4-dioxane, reflux, $31 \mathrm{~h}$; (b) (1) $\mathrm{POCl}_{3}, \mathrm{CH}_{2} \mathrm{Cl}_{2}$, rt, $24 \mathrm{~h}$, (2) 22, $\mathrm{CH}_{2} \mathrm{Cl}_{2}, 35^{\circ} \mathrm{C}, 24 \mathrm{~h}$; (c) (1) LiHMDS, THF, $0{ }^{\circ} \mathrm{C}, 1.5 \mathrm{~h}$, (2) 16, THF, $-15{ }^{\circ} \mathrm{C}$, 16 h. ${ }^{a}$ The reaction mixture initially consisted of $36 \mathrm{~mol} \%$ of $\mathbf{2 1 a}$ and $64 \mathrm{~mol} \%$ of $\mathbf{1 4 d}$. ${ }^{b}$ Determination of ee via chiral HPLC analysis. ${ }^{c}$ After recrystallization from $\mathrm{CH}_{3} \mathrm{CN}$.

Preparation of $(S)$-2,3-dihydro-1H-pyrrolo[2,3-c']blebbistatin $(S)$-8 and $(S)$-1H-pyrrolo[2,3$c^{\prime}$ ']blebbistatin $(S)$-10 started from 6-bromoindole (23) (Scheme 4), which was selectively protected to yield allylated indole $\mathbf{2 4}$ (step (a), 99\%) [29]. The feasibility to remove the allyl protecting group from the indole moiety was tested using a first generation Grubbs' carbene catalyst [30], but this attempt failed. As successful allyl deprotection of aliphatic amines had been reported previously by us [19], we opted to reduce allylated indole $\mathbf{2 4}$ to indoline $\mathbf{1 9 b}$ (step (b), 80\%) [29] and reoxidize it further down the line. Pyrrolidinone 21b was synthesized from indoline 19b with $N, N^{\prime}$-dimethylethylenediamine and $\mathrm{K}_{2} \mathrm{CO}_{3}$ (step (c), 99\%). Next, the amidine 14e synthesis proved difficult (step (d), 42\%) due to the electron withdrawing amino group (protonated under the reaction conditions used) present on the aryl amide. Subsequent 
one-pot intramolecular ring closure and enantioselective hydroxylation (step (e), 51\%, ee $80 \%$ ) afforded a mixture containing $86 \%$ of compound $(S)-25$ and $14 \%$ of oxidation product (S)-26, which was not the result of oxidized impurities present in the starting material. The moderate yield was caused by the tough isolation via acid-base extraction. Recrystallization from $\mathrm{CH}_{3} \mathrm{CN}$ resulted in an enantiopure mixture (ee >99\%) containing $91 \%$ of $(S)-25$ and $9 \%$ of $(S)$-26. This mixture was used for the synthesis of $(S)$-2,3-dihydro-1H-pyrrolo[2,3$c$ ']blebbistatin $(S)-8$ (step (f), 73\%, ee >99\%), which was separated from the unreacted $(S)$-26 via chromatography. Finally, oxidation of intermediate $(S)-\mathbf{8}$ with $\mathrm{MnO}_{2}$ yielded $(S)-1 H$ pyrrolo[2,3-c']blebbistatin $(S)-\mathbf{1 0}($ step $(\mathrm{g}), \mathbf{7 0 \%}$, ee >99\%).
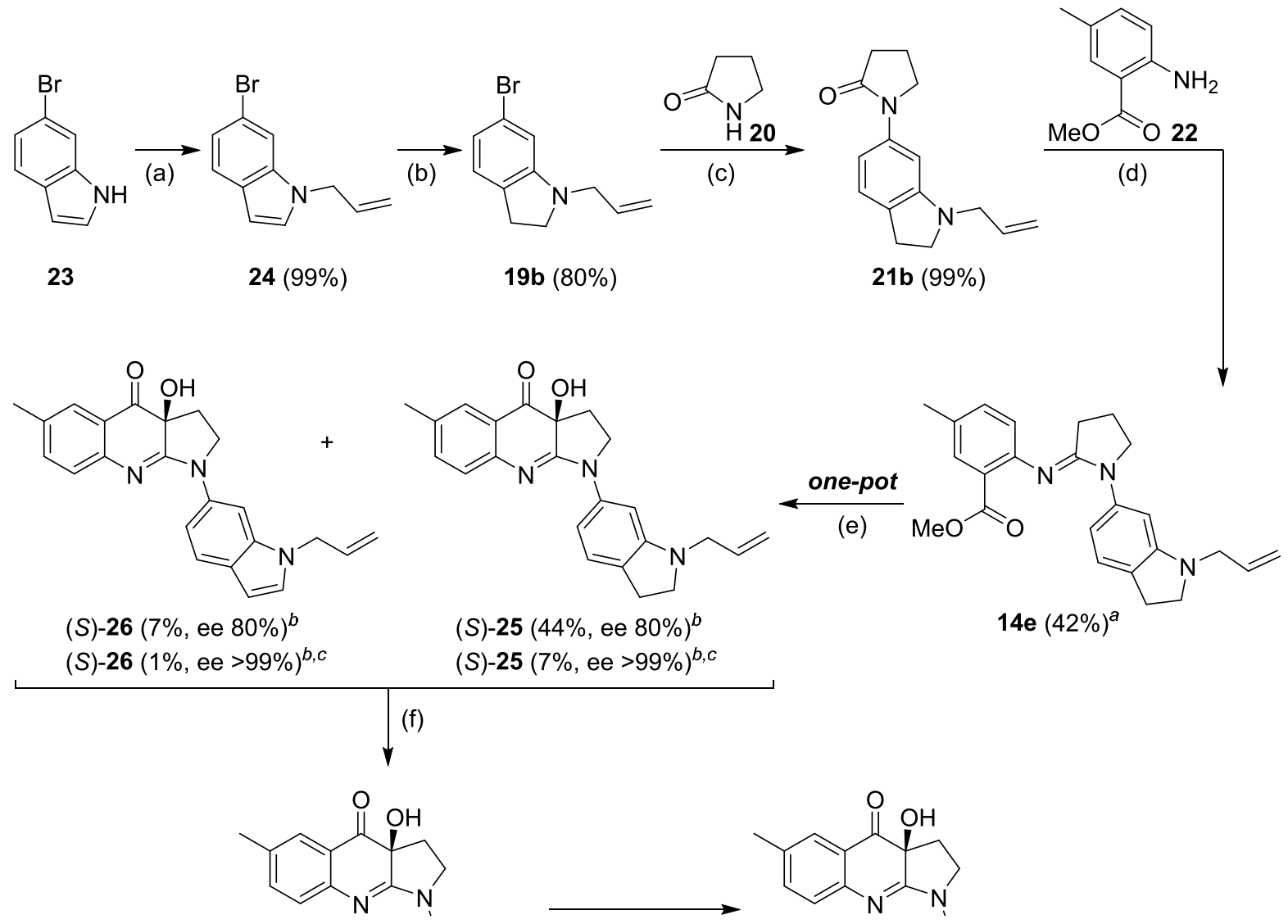

Scheme 4. Synthesis of (S)-2,3-dihydro-1H-pyrrolo[2,3-c']blebbistatin $(S)$-8 and $(S)-1 H$ pyrrolo[2,3-c']blebbistatin (S)-10. Reagents and conditions: (a) (1) $\mathrm{NaH}, \mathrm{DMF}, 0{ }^{\circ} \mathrm{C}, 30 \mathrm{~min}$, (2) allyl bromide, DMF, rt, 30 min; (b) $\mathrm{NaCNBH}_{3}$, glacial acetic acid, rt, 4.5 h; (c) CuI, $N, N^{\prime}$ dimethylethylenediamine, 20, $\mathrm{K}_{2} \mathrm{CO}_{3}$, 1,4-dioxane, reflux, $33 \mathrm{~h}$; (d) (1) $\mathrm{POCl}_{3}, \mathrm{CH}_{2} \mathrm{Cl}_{2}$, rt, $24 \mathrm{~h}$, (2) 22, $\mathrm{CH}_{2} \mathrm{Cl}_{2}, 35^{\circ} \mathrm{C}, 48 \mathrm{~h}$; (e) (1) LiHMDS, THF, $0{ }^{\circ} \mathrm{C}, 2 \mathrm{~h}$, (2) 16, THF, $-15^{\circ} \mathrm{C}$, 
16 h; (f) $N, N^{\prime}$-dimethylbarbituric acid, $\mathrm{Pd}\left(\mathrm{PPh}_{3}\right)_{4}, \mathrm{CH}_{2} \mathrm{Cl}_{2}$, reflux, 1 h; (g) $\mathrm{MnO}_{2}, \mathrm{CHCl}_{3}, \mathrm{rt}$, $3 \mathrm{~h} .{ }^{a}$ The reaction mixture initially consisted of $37 \mathrm{~mol} \%$ of $\mathbf{2 1 b}$ and $63 \mathrm{~mol} \%$ of 14e. ${ }^{b}$ Determination of ee via chiral HPLC analysis by comparison of $(R)$-enantiomer enriched fractions. ${ }^{c}$ After recrystallization from $\mathrm{CH}_{3} \mathrm{CN}$.

(S)-4'-Allyloxyblebbistatin $(S)$-12 was prepared from 4-iodophenol (27) by allyl protection (step (a), quant) [31], $N$-arylation of 2-pyrrolidinone (20) (step (b), 75\%) and amidine $\mathbf{1 4 f}$ synthesis (step (c), 78\%) (Scheme 5). Amidine 14f was completely converted to $\alpha$-hydroxy ketone $(S)$-12, using our improved two-step one-pot procedure, but was isolated in a moderate yield (step (d), 43\%, ee 82\%). A single recrystallization from $\mathrm{CH}_{3} \mathrm{CN}$ and subsequent allyl deprotection afforded enantiopure $(S)$-4'-allyloxyblebbistatin $(S)-12$ (ee >99\%) and $(S)-4$ 'hydroxyblebbistatin $(S)$-11 (step (e), 77\%, ee >99\%), respectively. The latter was further modified with benzyl bromide, delivering $(S)-4$ '-benzyloxyblebbistatin $(S)$-13 (step (f), 62\%, ee $>99 \%)$.<smiles>Oc1ccc(I)cc1</smiles>

(a)

27<smiles>C=CCOc1ccc(I)cc1I</smiles>
28 (quant)<smiles>Cc1ccc2c(c1)C(=O)C1(O)CCN(c3ccccc3)C1=N2</smiles>

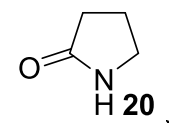

(b)<smiles>C=CCOc1ccc(N2CCCC2=O)cc1</smiles>
21c $(75 \%)$<smiles>COC(=O)c1cc(C)ccc1N</smiles>

(c)<smiles>C=CCOc1ccc(N2CCCC2=Nc2ccc(C)cc2C(=O)OC)cc1</smiles>

$14 f(78 \%)$ (d)

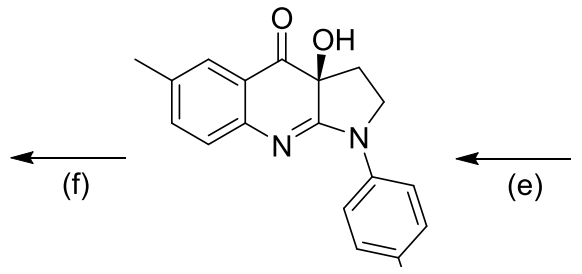<smiles>Cc1ccc2c(c1)C(=O)C1(O)CCN(c3ccccc3)C1=N2</smiles>

Scheme 5. Synthesis of $(S)-4$ '-allyloxyblebbistatin $(S)-12,(S)-4$ '-hydroxyblebbistatin $(S)-11$ and (S)-4'-benzyloxyblebbistatin (S)-13. Reagents and conditions: (a) TBAB, allyl bromide, 25\% aq NaOH/2-mTHF (3:2), reflux, 30 min; (b) CuI, 20, tris(3,5-dimethyl-1H-pyrazol-1yl)methane, $\mathrm{K}_{3} \mathrm{PO}_{4}, 1$,4-dioxane, reflux, $24 \mathrm{~h}$; (c) (1) $\mathrm{POCl}_{3}, \mathrm{CH}_{2} \mathrm{Cl}_{2}$, rt, 24 h, (2) 22, $\mathrm{CH}_{2} \mathrm{Cl}_{2}$, $35{ }^{\circ} \mathrm{C}, 24 \mathrm{~h}$; (d) (1) LiHMDS, THF, $0{ }^{\circ} \mathrm{C}, 1.5 \mathrm{~h}$, (2) 16, THF, $-15{ }^{\circ} \mathrm{C}, 16 \mathrm{~h}$; (e) $\mathrm{Pd}\left(\mathrm{PPh}_{3}\right)_{4}$, $\mathrm{K}_{2} \mathrm{CO}_{3}, \mathrm{MeOH}, 50{ }^{\circ} \mathrm{C}, 1.5 \mathrm{~h}$; (f) $\mathrm{NaI}, \mathrm{Cs}_{2} \mathrm{CO}_{3}$, benzyl bromide, $\mathrm{CH}_{3} \mathrm{CN}, 50{ }^{\circ} \mathrm{C}, 1 \mathrm{~h}$. 
${ }^{a}$ Determination of ee via chiral HPLC analysis by comparison with $(R)$-enantiomer enriched fractions. ${ }^{b}$ After recrystallization from $\mathrm{CH}_{3} \mathrm{CN} .{ }^{c}$ Ee derived from ee of $(S)-\mathbf{1 3} .{ }^{d}$ The reaction mixture initially consisted of 94 mol\% of $(S)-\mathbf{1 3}$ and 6 mol\% of dibenzylated product.

In order to compare the newly synthesized $(S)$-blebbistatin derivatives with existing literature compounds, the synthesis of $(S)$-4'-nitroblebbistatin $(S)$-29 and $(S)$-4'-aminoblebbistatin $(S)$ 31 was also performed. Preparation of $(S)$-4'-nitroblebbistatin $(S)$-29 via direct nitration of $(S)$-blebbistatin $(S)$-1 resulted in a complex mixture (Scheme 6, step (a)), so we opted to prepare it starting from pyrrolidinone 21d, as reported by Képiró et al. [17]. In our hands, synthesis of the latter by nitration of $N$-phenylpyrrolidin-2-one was not selective: a mixture of $70 \%$ of 4'-nitrated, $10 \%$ of 2'-nitrated and $20 \%$ of 2',4'-dinitrated material was obtained, which proved difficult to purify. However, pyrrolidinone 21d could be synthesized from 1bromo-4-nitrobenzene (19c) and 2-pyrrolidinone (20) in excellent yield (step (b), 95\%). As observed by Képiró et al. [17], formation of amidine $\mathbf{1 4 g}$ was difficult due to the highly electron withdrawing nitro group (step (c), 20\%). Intramolecular ring closure upon treatment with LiHMDS was accompanied by production of dimer 30 (step (d) (1)), a side-reaction which was never observed before with other derivatives. Nevertheless, we were able to increase the yield of $(S)-4$ '-nitroblebbistatin $(S)$-29 from previously reported $11 \%$ [17] to 38\% via our improved one-pot intramolecular ring closure and enantioselective hydroxylation (step (d), 38\%, ee 82\%). Enantiopure (S)-4'-nitroblebbistatin $(S)$-29 was obtained after recrystallization from $\mathrm{CH}_{3} \mathrm{CN}$ (ee $>99 \%$ ). Reduction of the nitro group, using 10 equivalents of ammonium formate, resulted in a conversion of $50 \%$ and the isolation of $(S)-4$ 'aminoblebbistatin $(S)-\mathbf{3 1}$ in $31 \%$ yield. 


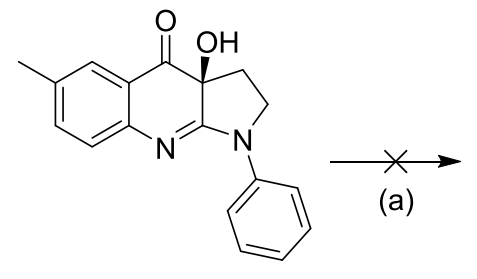

$(S)-1($ ee $>99 \%)$

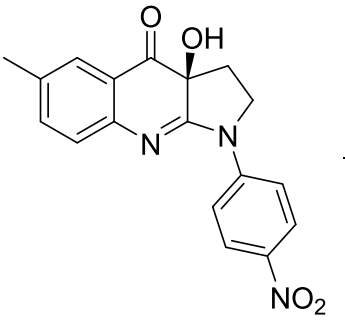

(S)-29 $(38 \% \text {, ee } 82 \%)^{b, c}$

(S)-29 $(20 \% \text {, ee }>99 \%)^{c, d}$

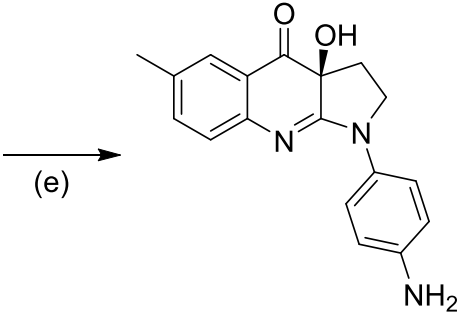

$(S)-31(31 \%)^{e}$
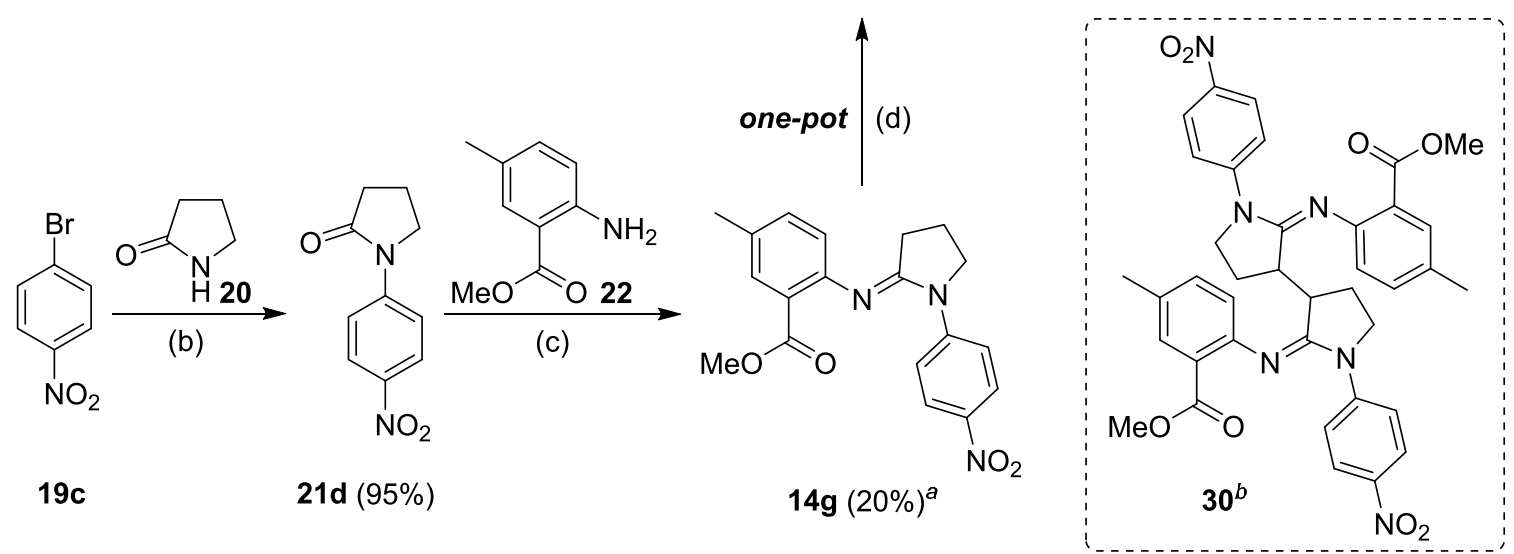

Scheme 6. Synthesis of (S)-4'-nitroblebbistatin $(S)$-29 and $(S)-4$ '-aminoblebbistatin $(S)-\mathbf{3 1}$. Reagents and conditions: (a) $\mathrm{HNO}_{3}, \quad \mathrm{H}_{2} \mathrm{SO}_{4}, \quad 0^{\circ} \mathrm{C}, 30 \mathrm{~min} ;$ (b) $\mathrm{CuI}, \quad N, N^{\prime}-$ dimethylethylenediamine, 20, $\mathrm{K}_{2} \mathrm{CO}_{3}, 1$,4-dioxane, reflux, $18 \mathrm{~h}$; (c) (1) $\mathrm{POCl}_{3}, \mathrm{CH}_{2} \mathrm{Cl}_{2}, \mathrm{rt}$, $24 \mathrm{~h}$, (2) 22, $\mathrm{CH}_{2} \mathrm{Cl}_{2}, 35^{\circ} \mathrm{C}, 4$ days; (d) (1) LiHMDS, THF, $0{ }^{\circ} \mathrm{C}, 1 \mathrm{~h}$, (2) 16, THF, $-15^{\circ} \mathrm{C}$, $16 \mathrm{~h}$; (e) ammonium formate, $\mathrm{Pd} / \mathrm{C}, \mathrm{MeOH}, \mathrm{rt}, 15 \mathrm{~min} .{ }^{a}$ The reaction mixture initially consisted of $80 \mathrm{~mol} \%$ of $\mathbf{2 1 d}$ and $20 \mathrm{~mol} \%$ of $\mathbf{1 4 g} .{ }^{b} 41 \%$ and $59 \%$ of $\mathbf{1 4 g}$ was converted to $(S)$-29 and 30, respectively. ${ }^{c}$ Determination of ee via chiral HPLC analysis. ${ }^{d}$ After recrystallization from $\mathrm{CH}_{3} \mathrm{CN} .{ }^{e}$ The reaction mixture initially consisted of 50 mol\% of $(S)-29$ and $50 \mathrm{~mol} \%$ of $(S)-31$.

\subsection{Biochemical evaluation}

The newly synthesized (S)-blebbistatin derivatives $(S)$-2-13 and literature analogs $(S)$-29 and (S)-31 were evaluated in vitro for their myosin II inhibitory potency in a steady-state ATPase assay using rabbit skeletal muscle myosin II. In these studies, $(S)$-blebbistatin $(S)$-1 was used as a benchmark. Dose-response curves are presented in Figure 3 and Figure S1 in the Supporting Information. The half-maximum inhibitory concentrations $\left(\mathrm{IC}_{50}\right)$ and potencies relative to $(S)-\mathbf{1}$, expressed as the ratio of the $\mathrm{IC}_{50}$ of $(S)-\mathbf{1}$ to the compound $\mathrm{IC}_{50}$, are summarized in Table 1. 
A

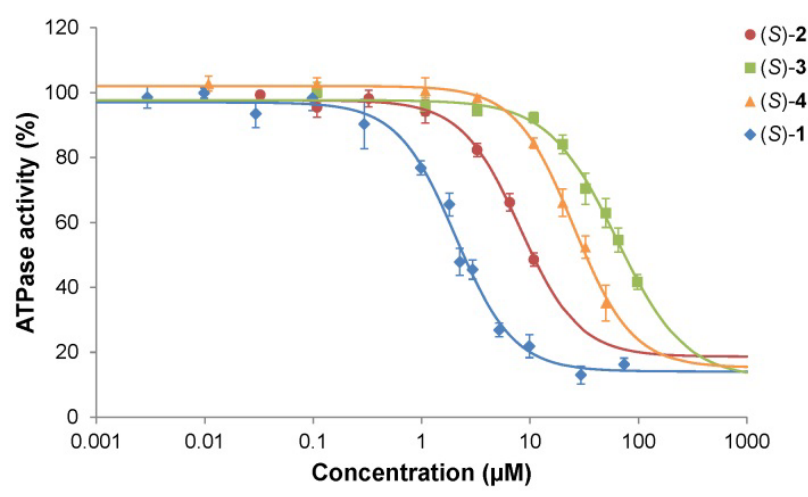

B

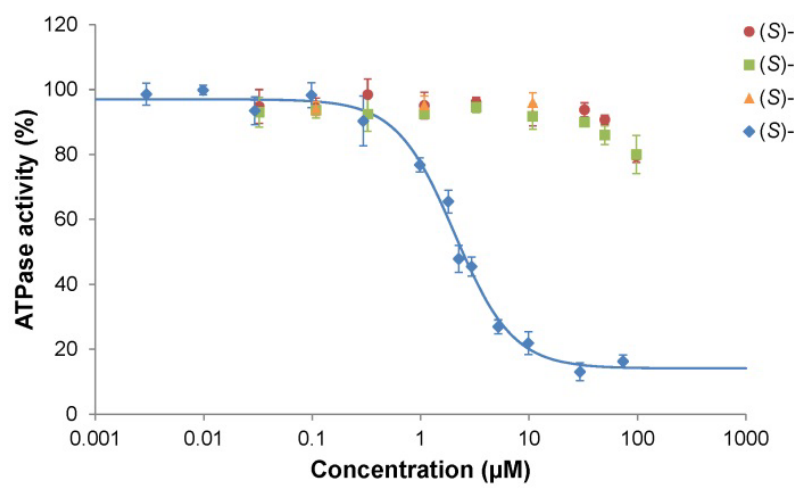

$\mathrm{C}$

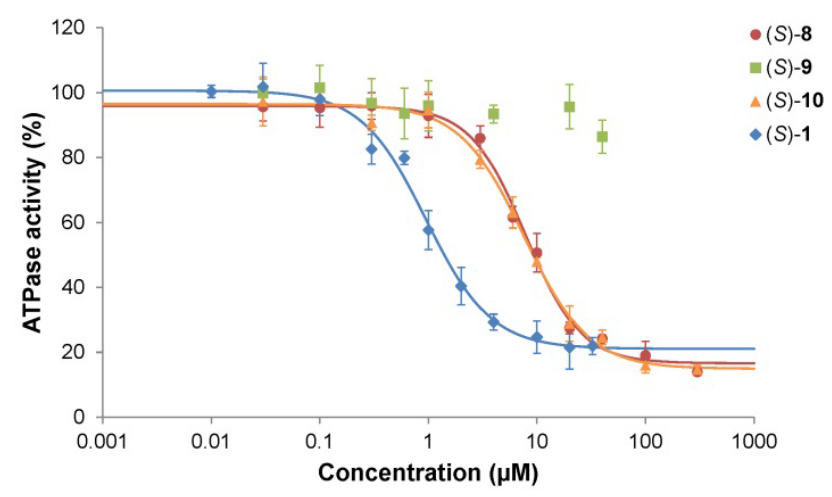

D

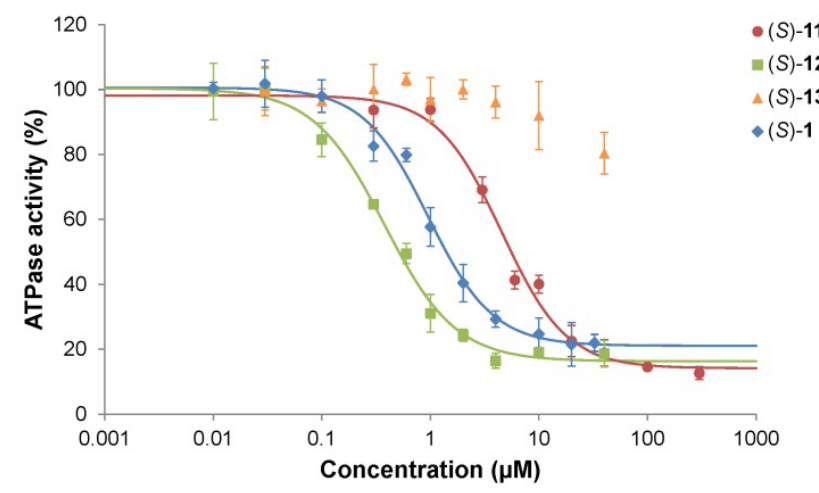

Figure 3. Overview of the myosin II inhibitory properties of compounds $(S)$-2-13, evaluated in an ATPase assay with rabbit skeletal muscle myosin II. Examples of dose-response curves and 4-parameter logistic curve fitting obtained for (A) (S)-3'-allyloxyblebbistatin $(S)$-2, $(S)$ 3'-acryloxyblebbistatin (S)-3 and (S)-3'-propionyloxyblebbistatin $(S)-4$, (B) (S)-3'acrylamidoblebbistatin $\quad(S)-5, \quad(S)$-3'-propionylamidoblebbistatin $\quad(S)$-6 and $(S)$-3'diallylaminoblebbistatin $(S)$-7, (C) $(S)$-2,3-dihydro-1H-pyrrolo[2,3-c']blebbistatin $(S)$-8, $(S)$ benzo[c']blebbistatin (S)-9 and $(S)$-1H-pyrrolo[2,3-c']blebbistatin (S)-10 and (D) (S)-4'hydroxyblebbistatin $\quad(S)$-11, $\quad(S)$-4'-allyloxyblebbistatin $\quad(S)-\mathbf{1 2} \quad$ and $\quad(S)-4^{\prime}$ benzyloxyblebbistatin $(S)$-13. Data points represent the mean \pm s.d. of at least three samples $(\mathrm{N}=1)$. (S)-blebbistatin $(S)-\mathbf{1}$ is shown as a benchmark. Compound concentrations exceeding $10.8 \mu \mathrm{M}, 100 \mu \mathrm{M}$ and $50 \mu \mathrm{M}$ resulted in precipitation of $(S)-2,(S)-3$ and $(S)-4$, respectively, in the assay buffer. As an approximation, the relative ATPase activity obtained for $(S)$ blebbistatin $(S)-\mathbf{1}$ at a concentration of $32.5 \mu \mathrm{M}$ was used to set the lower asymptote of the fitted curve for these compounds. 
Table 1. Evaluation of the myosin II inhibitory properties of compounds $(S)$-1-13: halfmaximum inhibitory concentrations $\left(\mathrm{IC}_{50}\right)$ for the steady-state ATPase activity of rabbit skeletal muscle myosin II., ${ }^{a, b}$

\begin{tabular}{ccc|ccc}
\hline Compound & $\begin{array}{c}\mathbf{I C}_{\mathbf{5 0}} \\
(\boldsymbol{\mu M})\end{array}$ & $\begin{array}{c}\text { Relative potency } \\
\text { to }(\boldsymbol{S})-\mathbf{1}\end{array}$ & Compound & $\begin{array}{c}\mathbf{I C}_{\mathbf{5 0}} \\
(\boldsymbol{\mu} \mathbf{M})\end{array}$ & $\begin{array}{c}\text { Relative potency } \\
\text { to }(\boldsymbol{S})-\mathbf{1}\end{array}$ \\
\hline$(S)-\mathbf{1}$ & $2.16 \pm 0.14$ & $1.0 \pm 0.1$ & $(S)-\mathbf{1}$ & $0.873 \pm 0.114$ & $1.0 \pm 0.2$ \\
$(S)-\mathbf{2}$ & $9.41 \pm 1.83$ & $0.23 \pm 0.05$ & $(S)-\mathbf{8}$ & $7.70 \pm 0.19$ & $0.11 \pm 0.02$ \\
$(S)-\mathbf{3}$ & $57.6 \pm 7.8$ & $0.04 \pm 0.01$ & $(S)-\mathbf{9}$ & $>40^{e}$ & $<0.02$ \\
$(S)-\mathbf{4}$ & $23.5 \pm 2.5$ & $0.09 \pm 0.01$ & $(S)-\mathbf{1 0}$ & $7.20 \pm 0.59$ & $0.12 \pm 0.02$ \\
$(S)-\mathbf{5}$ & $>100^{c}$ & $<0.02$ & $(S)-\mathbf{1 1}$ & $5.47 \pm 1.32$ & $0.16 \pm 0.04$ \\
$(S)-\mathbf{6}$ & $>100^{c}$ & $<0.02$ & $(S)-\mathbf{1 2}$ & $0.380 \pm 0.003$ & $2.3 \pm 0.3$ \\
$(S)-\mathbf{7}$ & $>10.8^{d}$ & - & $(S)-\mathbf{1 3}$ & $>40^{e}$ & $<0.02$ \\
\hline
\end{tabular}

${ }^{a}$ Compounds (S)-2-7 and (S)-8-13 were evaluated with a different batch of rabbit skeletal muscle myosin II, resulting in a different protein activity. In both series, this deviation was accounted for by expressing the $\mathrm{IC}_{50}$ of each compound relative to the respective $\mathrm{IC}_{50}$ of $(S)$ 1. ${ }^{b}$ Data represent the mean \pm s.d. of two independent experiments. ${ }^{c}$ Highest compound concentration used was $100 \mu \mathrm{M}$. ${ }^{d}$ Highest compound concentration used was $10.8 \mu \mathrm{M}$, as concentrations higher than $10.8 \mu \mathrm{M}$ resulted in compound precipitation in the assay buffer. ${ }^{e}$ Highest compound concentration used was $40 \mu \mathrm{M}$.

From these and literature data [19], some patterns can be recognized regarding the influence of substitution on myosin II inhibitory activity (presented as relative potency to $(S)$-1 in Table 2). First, small groups are equally well tolerated in the 4'-position as in the 3'-position $((S)-\mathbf{1 1}$ and (S)-31 vs $(S)$-17 and $(S)-\mathbf{1 8}$, respectively). However, for medium-sized groups, 4'substitution of ring $\mathrm{D}$ is preferred over 3'-substitution $((S)-\mathbf{1 2}$ vs $(S)$-2). Finally, large substituents $((S)-33,(S)-34,(S)-9,(S)-5,(S)-6$ and $(S)$-13) are not compatible with the binding pocket, at either position. 
Table 2. Overview of present and literature data of the rabbit skeletal muscle myosin II inhibitory properties of compounds $(S)-\mathbf{1 - 1 3}, \mathbf{1 7}, \mathbf{1 8}, \mathbf{2 9}, \mathbf{3 1 - 3 4}$, expressed as the relative potency to $(S)-\mathbf{1}^{a, b}$

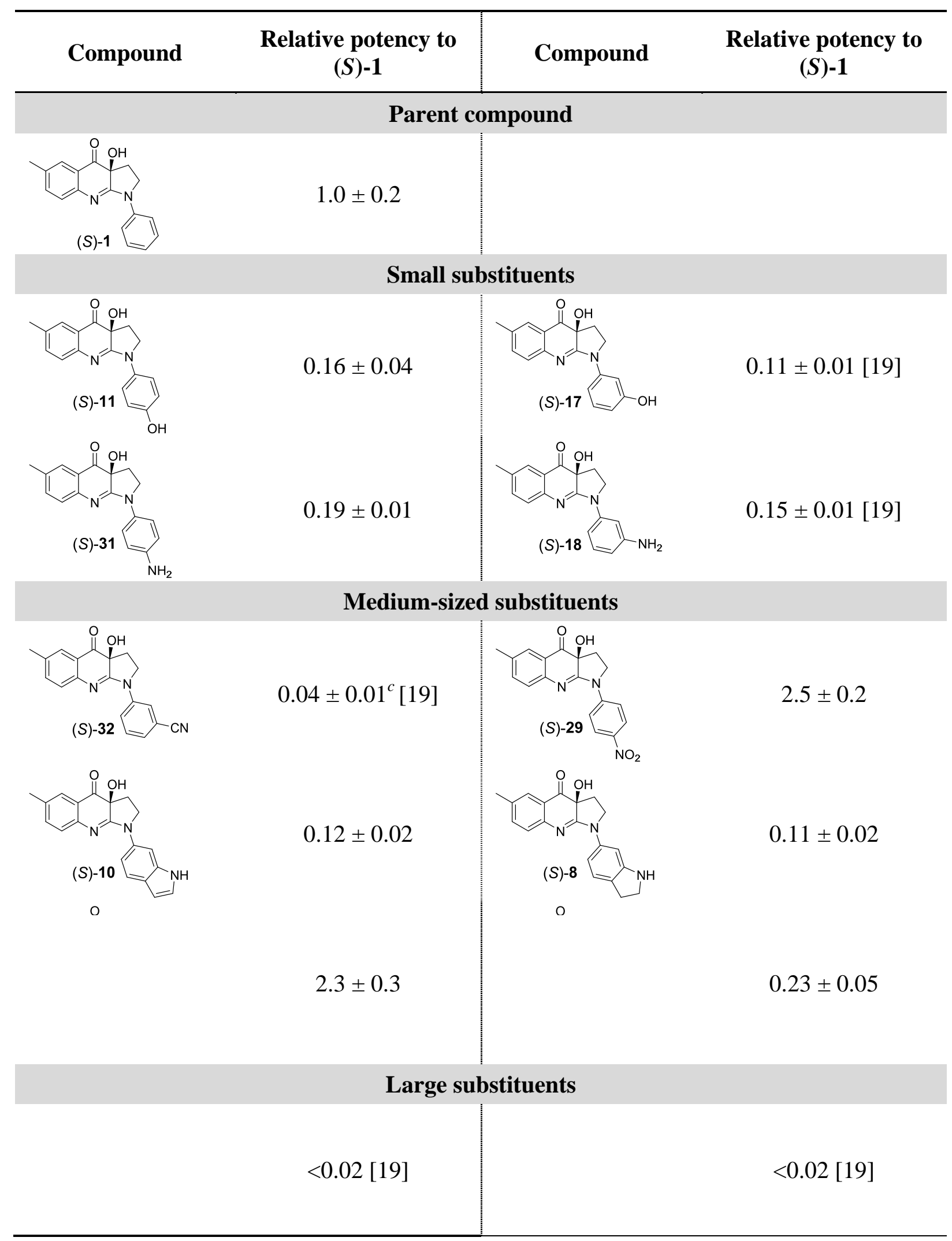




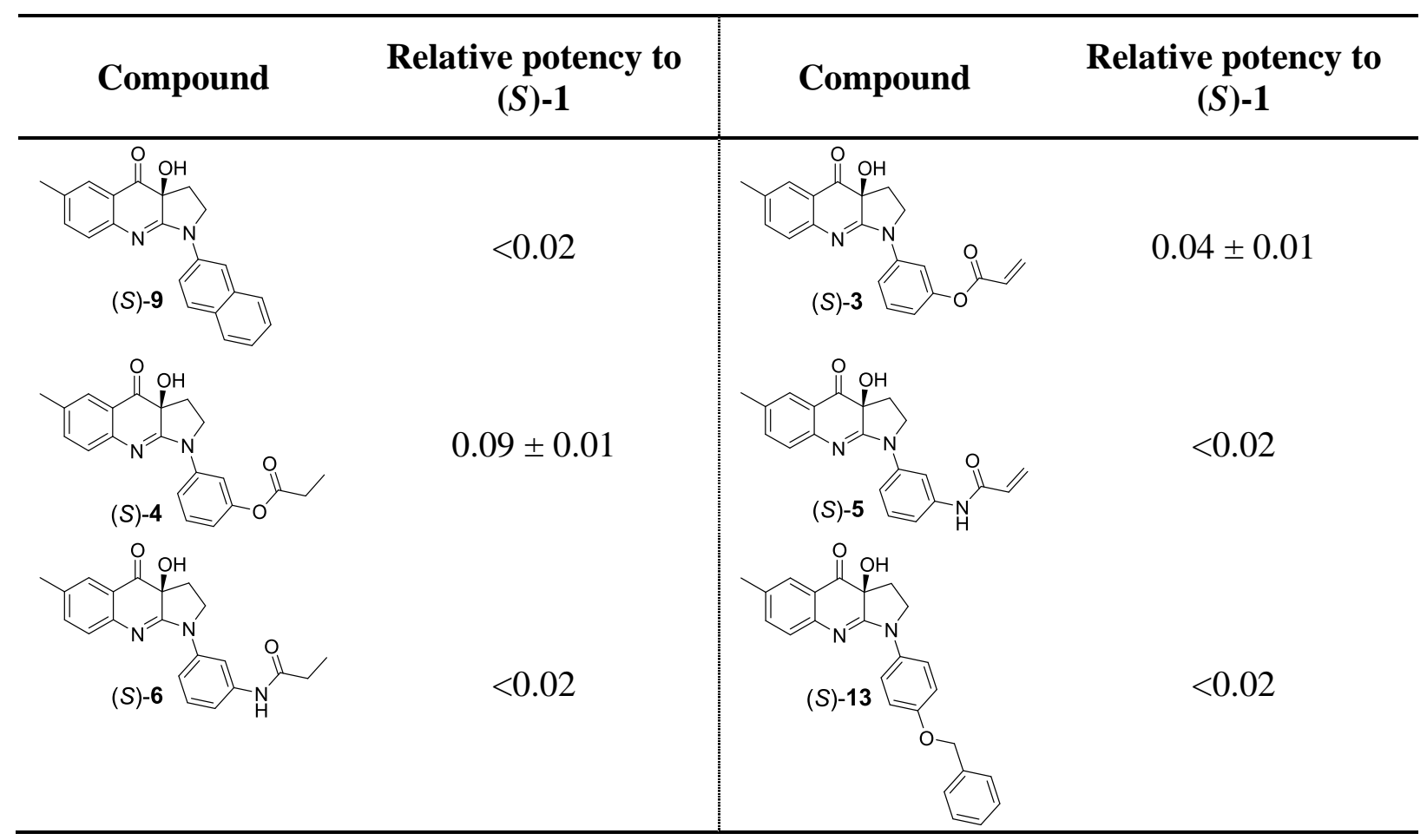

${ }^{a}(S)$-3'-diallylaminoblebbistatin (S)-7 is not included, as compound precipitation occurred at a concentration of $10.8 \mu \mathrm{M}$. 4'-Azidoblebbistatin and 4'-chloroblebbistatin are not included, because no literature data are available for the rabbit skeletal muscle myosin II inhibitory properties of these compounds $[17,20] .{ }^{b}$ Data represent the mean \pm s.d. of two independent experiments. ${ }^{c}$ Ee $84 \%$.

In all, these structure-activity relationships indicate that D-ring substitution does not lead to significant potency enhancement. However, this part of the $(S)$-blebbistatin scaffold can be used to fine-tune the physicochemical profile of the molecule, without affecting the biological activity in an appreciable manner. For instance, disadvantages related to the use of $(S)$ blebbistatin (S)-1 as a research tool are (i) photosensitivity when using fluorescence microscopy with blue light irradiation (400-500 nm) to visualize GFP-labeled myosin II and (ii) low aqueous solubility and ensuing interference of precipitates in read-outs [19,32-40]. Therefore, $(S)$-blebbistatin $(S)$-1 and the most potent analogs $(S)$-3'-allyloxyblebbistatin $(S)$-2, $(S)-4$ '-hydroxyblebbistatin $\quad(S)$-11, $\quad(S)$-4'-allyloxyblebbistatin $\quad(S)$-12, $\quad(S)$-3' hydroxyblebbistatin $(S)$-17, $(S)$-3'-aminoblebbistatin $(S)$-18, $(S)-4$ '-nitroblebbistatin $(S)-29$ and $(S)-4$ '-aminoblebbistatin $(S)$-31 were evaluated for their photostability, water solubility and cell membrane permeability. 


\subsection{Photostability}

Qualitative literature data are available showing that $(S)$-blebbistatin $(S)$-1 is photodegradable upon blue light irradiation (400-500 nm), while $(S)-4$ '-nitroblebbistatin $(S)$-29 and $(S)-4$ 'aminoblebbistatin $(S)$-31 are not [16-18,32,35,37]. However, up till now, quantification of this behavior is lacking. We therefore developed a suitable experimental setup to generate half-life curves.

Using a fluorescence spectrometer (F900, Edingburgh Instruments) equipped with a $450 \mathrm{~W}$ Xenon Lamp, Képiró et al. reported degradation of $(S)$-blebbistatin $(S)$-1 after 5 min of irradiation at $480 \pm 10 \mathrm{~nm}[17,18]$. Initially, we applied this setup to examine the timedependent effect of blue light irradiation on the absorption spectrum of the latter compound. However, irradiating $20 \mu \mathrm{M}$ samples of $(S)$-blebbistatin $(S)$-1 in phosphate-buffered saline (PBS) (containing 2.67\% (v/v) methanol) for $30 \mathrm{~min}$ at $488 \mathrm{~nm}$ did not result in any degradation (Figure 4A). Therefore, we changed the setup and solutions of $(S)$-blebbistatin (S)-1 in DMSO and DMSO/ $\mathrm{H}_{2} \mathrm{O}(1: 1)$, with concentrations ranging from $100 \mu \mathrm{M}$ to $600 \mu \mathrm{M}$, were irradiated with a fluorescent tube lamp emitting 390-470 nm with a maximum at $420 \mathrm{~nm}$ (Figure S2 in the Supporting Information) [35]. Decomposition of $(S)$-blebbistatin $(S)$-1 was followed up in time by HPLC. As depicted by Figure 4B and Figure S3, degradation required the presence of water: at all concentrations evaluated, hardly any decomposition could be observed when $100 \%$ DMSO was used as solvent. Figure 4C shows the dependence of $(S)$ blebbistatin $(S)$-1 half-life on concentration, which follows a linear pattern. Illumination times exceeding two hours resulted in substantial evaporation of solvent, making quantification of degradation impossible. A concentration of $100 \mu \mathrm{M}$ was therefore used in further experiments to obtain sufficient degradation within 90 min of irradiation. Finally, the photosensitivity of $(S)$-blebbistatin $(S)$-1 was studied in an aqueous medium that mimics the conditions of cell experiments, i.e. a 1:1 mixture of DMSO and DMEM supplemented with 20\% (v/v) fetal calf serum (Figure 4D). The observed reduction in half-life (Figure 4D vs Figure 4B) indicates that observations made in simple aqueous media cannot be extrapolated to complex biological media. The stability of the $(S)$-blebbistatin derivatives was therefore also assessed in a 1:1 mixture of DMSO and DMEM supplemented with 20\% (v/v) fetal calf serum [41].

Figure 5 illustrates the decomposition of $(S)$-3'-allyloxyblebbistatin $(S)-2$, $(S)-4$ 'hydroxyblebbistatin $(S)-\mathbf{1 1},(S)-4$ '-allyloxyblebbistatin $(S)$-12, $(S)$-3'-hydroxyblebbistatin $(S)$ -
17, (S)-3'-aminoblebbistatin
$(S)-\mathbf{1 8}, \quad(S)-4$ '-nitroblebbistatin
(S)-29 and
(S)-4'- 
aminoblebbistatin $(S)$-31 in function of time and the half-life of these compounds is summarized in Table 3. Consistent with the observations of Képiró et al. [17], we found (S)4'-nitroblebbistatin (S)-29 to possess the highest stability after $90 \mathrm{~min}$ of irradiation. However, $(S)-4$ '-aminoblebbistatin $(S)$-31 already started to decompose after $10 \mathrm{~min}$, while this analog was expected to be equally stable as $(S)-4$ '-nitroblebbistatin $(S)$-29 [18]. Nonetheless, the latter compound still had a higher half-life than $(S)$-blebbistatin $(S)$-1. On the contrary, $\quad(S)$-3'-allyloxyblebbistatin $\quad(S)$-2, $\quad(S)$-3'-aminoblebbistatin $\quad(S)$-18, $\quad(S)$-3'hydroxyblebbistatin (S)-17 and (S)-4'-allyloxyblebbistatin $(S)$-12 displayed a similar resistance toward photodegradation as $(S)$-blebbistatin $(S)$-1. (S)-4'-Hydroxyblebbistatin $(S)$ 11 showed the lowest stability. 
A

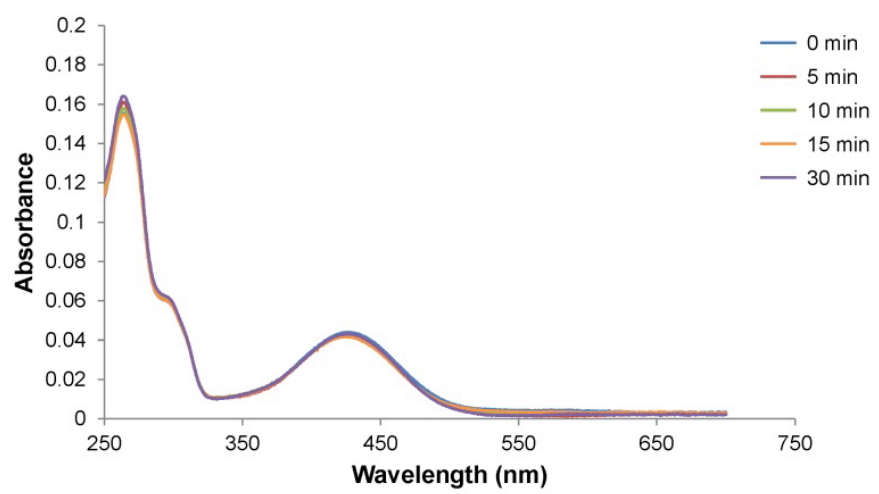

B

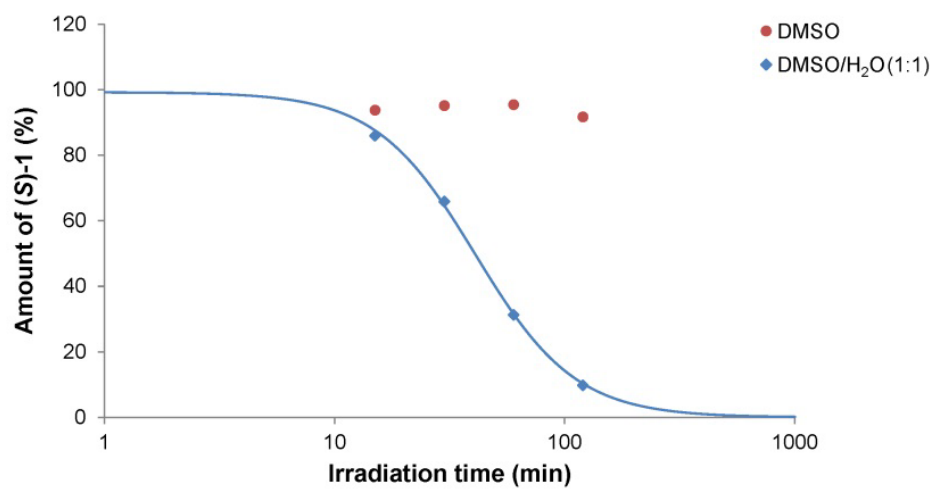

C

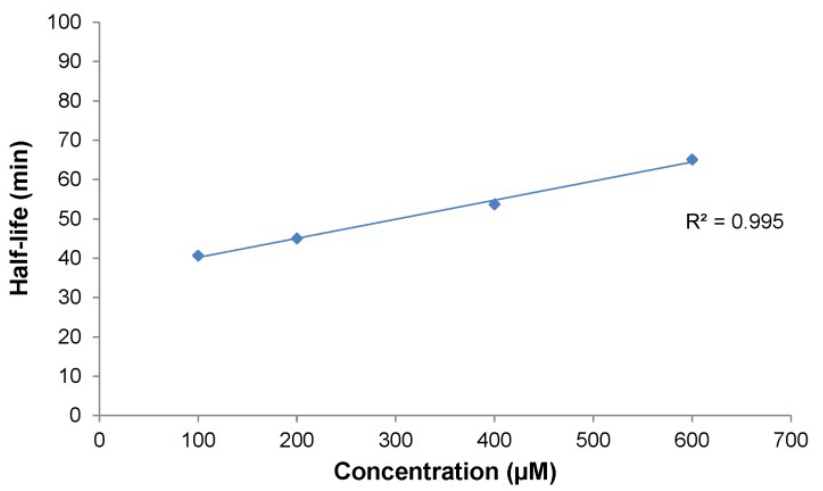

$\mathrm{D}$

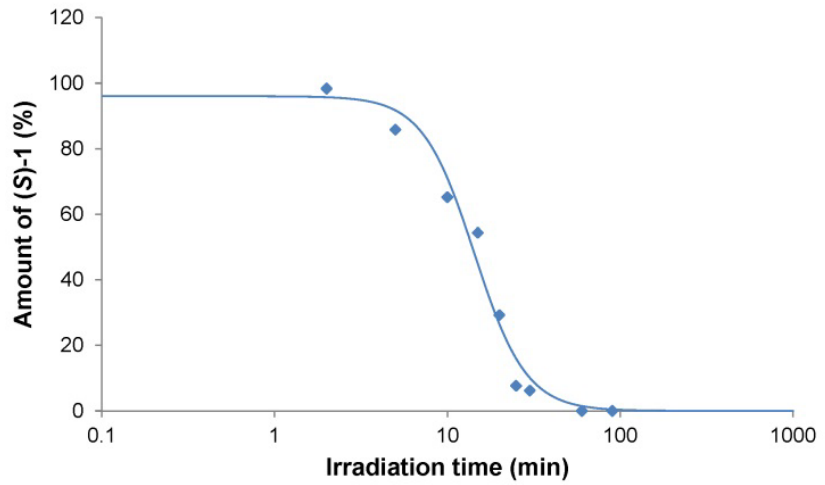

Figure 4. Investigation of photostability of $(S)$-blebbistatin $(S)$-1. (A) Absorbance spectra of $20 \mu \mathrm{M}(S)$-blebbistatin $(S)-\mathbf{1}$ in $\mathrm{PBS} / \mathrm{MeOH}(97.3: 2.7)$ after irradiation at $488 \mathrm{~nm}$ at the 
indicated times. (B) Degradation of $100 \mu \mathrm{M}(S)$-blebbistatin $(S)-\mathbf{1}$ in DMSO and DMSO/ $\mathrm{H}_{2} \mathrm{O}$ (1:1) after irradiation at 390-470 nm (maximum at $420 \mathrm{~nm}$ ) and 4-parameter logistic curve fitting (half-life is $39 \mathrm{~min}$ ). (C) Linear increase of $(S)$-blebbistatin $(S)$-1 degradation half-life in function of compound concentration in $\mathrm{DMSO} / \mathrm{H}_{2} \mathrm{O}(1: 1)$ after irradiation at 390-470 nm (maximum at $420 \mathrm{~nm}$ ). (D) Degradation of $100 \mu \mathrm{M}(S)$-blebbistatin $(S)$-1 in a 1:1 mixture of DMSO and DMEM supplemented with $20 \%$ (v/v) fetal calf serum after irradiation at 390$470 \mathrm{~nm}$ (maximum at $420 \mathrm{~nm}$ ) and 4-parameter logistic curve fitting (half-life is $14 \mathrm{~min}$ ).

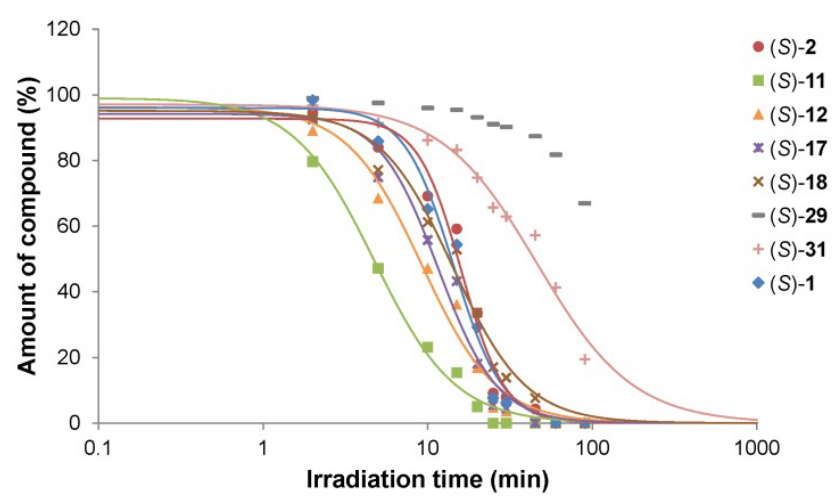

Figure 5. Investigation of photostability of (S)-3'-allyloxyblebbistatin (S)-2, (S)-4'hydroxyblebbistatin $(S)-\mathbf{1 1},(S)-4$ '-allyloxyblebbistatin $(S)$-12, $(S)$-3'-hydroxyblebbistatin $(S)$ 17, (S)-3'-aminoblebbistatin $(S)$-18, $\quad(S)$-4'-nitroblebbistatin $\quad(S)$-29 and (S)-4'aminoblebbistatin (S)-31 toward $390-470 \mathrm{~nm}$ (maximum at $420 \mathrm{~nm}$ ) irradiation. (S)blebbistatin (S)-1 is shown as a benchmark and 4-parameter logistic curve fitting was performed for all compounds except $(S)$-29. Compound concentrations were $100 \mu \mathrm{M}$ in a 1:1 mixture of DMSO and DMEM supplemented with $20 \%$ (v/v) fetal calf serum.

The observation that the presence of water is required to initiate degradation might question the correct use of the term photostability and it is tempting to speculate that a degradation product of water, e.g. hydroxyl or peroxy radicals, might be involved in the decay of $(S)$-blebbistatin $(S)$-1 and some of its derivatives. The photosensitizing ability of $(S)$ blebbistatin $(S)$-1 and ensuing generation of oxidative conditions upon blue light illumination was proven by Mikulich et al. [35]. Thus, its photosensitizing properties may be sufficient to generate hydroxyl or peroxy radicals in an aqueous mixture upon blue light irradiation, which in turn are able to induce oxidative degradation of $(S)$-blebbistatin $(S)$-1. Hence, $(S)$ blebbistatin $(S)$-1 might rather be prone to oxidative degradation than to photodegradation. This would explain why an analog bearing an electron withdrawing group does not 
decompose under the applied conditions. Further experiments are required to prove this hypothesis (but are beyond the scope of the present report).

Table 3. Overview of key tool properties of $(S)$-blebbistatin $(S)-1$ and analogs $(S)$-3'allyloxyblebbistatin $(S)-2,(S)-4$ '-hydroxyblebbistatin $(S)$-11, $(S)$-4'-allyloxyblebbistatin $(S)$ 12, $(S)$-3'-hydroxyblebbistatin $(S)$-17, $(S)$-3'-aminoblebbistatin $(S)$-18, $(S)$-4'-nitroblebbistatin (S)-29 and (S)-4'-aminoblebbistatin (S)-31: myosin II inhibitory potency (expressed as relative potency to $(S)$-1), photostability (expressed as half-life, $t_{1 / 2}$ ), steady-state aqueous solubility and Caco-2 apical-to-basolateral (A-B) and basolateral-to-apical (B-A) cell membrane permeability (expressed as apparent permeability, $\mathrm{P}_{\text {app}}$ ).

\begin{tabular}{|c|c|c|c|c|c|c|c|}
\hline \multirow[t]{2}{*}{ Compound } & \multirow{2}{*}{$\begin{array}{c}\text { Relative } \\
\text { potency to }(S)- \\
1^{a}\end{array}$} & \multirow{2}{*}{$\begin{array}{c}t_{1 / 2} \\
(\mathrm{~min})\end{array}$} & \multirow{2}{*}{$\begin{array}{c}\text { Solubility }^{a, b} \\
\qquad(\mu \mathrm{M})\end{array}$} & \multicolumn{2}{|c|}{$\begin{array}{c}\mathbf{P}_{\mathrm{app}}{ }^{c} \\
\left(10^{-6} \mathrm{~cm} \mathrm{~s}^{-1}\right)\end{array}$} & \multicolumn{2}{|c|}{$\begin{array}{c}\text { Recovery }^{c} \\
(\%)\end{array}$} \\
\hline & & & & A-B & B-A & A-B & B-A \\
\hline$(S)-\mathbf{1}$ & $1.0 \pm 0.2$ & 14 & $6.18 \pm 0.08$ [19] & $60.5 \pm 1.8$ & $19.2 \pm 0.3$ & $66 \pm 1$ & $66 \pm 4$ \\
\hline$(S)-2$ & $0.23 \pm 0.05$ & 15 & $2.83 \pm 0.09$ & N.D. ${ }^{d}$ & N.D. ${ }^{d}$ & N.D. ${ }^{d}$ & N.D. ${ }^{d}$ \\
\hline$(S)-\mathbf{1 1}$ & $0.16 \pm 0.04$ & 4.7 & $82.4 \pm 9.7$ & N.D. ${ }^{d}$ & N.D. ${ }^{d}$ & N.D. ${ }^{d}$ & N.D. ${ }^{d}$ \\
\hline$(S)-12$ & $2.3 \pm 0.3$ & 8.8 & $2.75 \pm 0.05$ & $29.7 \pm 0.6$ & $7.58 \pm 0.05$ & $32 \pm 1$ & $65 \pm 1$ \\
\hline$(S)-\mathbf{1 7}$ & $0.11 \pm 0.01[19]$ & 11 & $193 \pm 1[19]$ & $28.5 \pm 0.3$ & $17.2 \pm 0.1$ & $49 \pm 1$ & $70 \pm 1$ \\
\hline$(S)-\mathbf{1 8}$ & $0.15 \pm 0.01[19]$ & 13 & $186 \pm 9[19]$ & $62.7 \pm 3.1$ & $26.2 \pm 0.1$ & $79 \pm 1$ & $74 \pm 4$ \\
\hline$(S)-29$ & $2.5 \pm 0.2$ & $>90^{e}$ & $31.7 \pm 1.6$ & $32.5 \pm 1.0$ & $2.23 \pm 0.02$ & $34 \pm 1$ & $72 \pm 1$ \\
\hline$(S)-\mathbf{3 1}$ & $0.19 \pm 0.01$ & 44 & $>200^{f}$ & $69.4 \pm 3.0$ & $31.1 \pm 3.5$ & $85 \pm 1$ & $82 \pm 1$ \\
\hline
\end{tabular}

${ }^{a}$ Data represent the mean \pm s.d. of two independent experiments. ${ }^{b}$ Steady-state solubility in PBS pH 7.4 buffer. ${ }^{c}$ Caco-2 A-B (pH 7.4/7.4) and B-A (pH 7.4/7.4) permeability; compound concentrations were $20 \mu \mathrm{M} .{ }^{d}$ Not determined. ${ }^{e}$ Sample collected after 90 min resulted in $33 \%$ degradation. ${ }^{f}$ Highest compound concentration used was $200 \mu \mathrm{M}$.

\subsection{Water solubility and cell membrane permeability}

The low aqueous solubility of $(S)$-blebbistatin $(S)$-1 and its ensuing precipitates pose a problem for read-outs in cell-based experiments. For these settings, the ideal tool compound should combine a good cell membrane permeability with a high aqueous solubility. The 
steady-state solubility of $(S)$-3'-allyloxyblebbistatin $(S)$-2, $(S)$-4'-hydroxyblebbistatin $(S)$-11, $(S)$-4'-allyloxyblebbistatin $(S)$-12, $(S)$-4'-nitroblebbistatin $(S)$-29 and $(S)$-4'-aminoblebbistatin (S)-31 was determined in PBS pH 7.4 buffer (2\% (v/v) DMSO) and was compared with our previously reported data of $(S)$-blebbistatin $(S)$-1, $(S)$-3'-hydroxyblebbistatin $(S)$-17 and $(S)$ 3'-aminoblebbistatin (S)-18 (Table 3) [19]. As expected [18], (S)-4'-aminoblebbistatin $(S)$-31, (S)-3'-hydroxyblebbistatin $(S)$-17 and $(S)$-3'-aminoblebbistatin $(S)$-18 showed the highest water solubility, while $(S)-4$ '-hydroxyblebbistatin $(S)$-11 was surprisingly less soluble than the latter.

Caco-2 apical-to-basolateral (A-B) and basolateral-to-apical (B-A) cell membrane permeation data were also collected. All compounds evaluated showed high A-B permeability $\left(\mathrm{P}_{\text {app }}\right.$ $>20 \times 10^{-6} \mathrm{~cm} \mathrm{~s}^{-1}$ ). Further, the high ratio of A-B to B-A permeability suggests that none of the compounds are substrates for efflux transporters. Compound concentrations in both donor and acceptor compartments were analyzed to identify potential underestimation of permeability. The low A-B recovery of $(S)-4$ '-allyloxyblebbistatin $(S)$-12, $(S)$-3'-hydroxyblebbistatin $(S)$-17 and $(S)-4$ '-nitroblebbistatin $(S)$-29 may be attributed to retention in the cell monolayer, nonspecific binding onto plastic, compound precipitation or degradation during assay incubation. As B-A recovery is significantly higher for these molecules, the low A-B recovery is likely due to retention. Interestingly, comparison between $(S)$-blebbistatin $(S)-\mathbf{1}$ and the highly water soluble analogs $(S)-\mathbf{1 7},(S)$-18 and $(S)$-31 revealed that the increase in aqueous solubility is not accompanied by a loss in cell membrane permeability. In cell-based screenings requiring high inhibitor concentrations and where precipitates might interfere with read-outs, these molecules are thus ideal substitutes for $(S)$-blebbistatin $(S)-\mathbf{1}$.

\section{Conclusions}

Novel D-ring modified (S)-blebbistatin analogs were prepared in a shorter and higher yielding synthesis of the blebbistatin scaffold. This was accomplished by conducting the intramolecular ring closure of amidines and subsequent $\alpha$-hydroxylation of the intermediate quinolones in a two-step one-pot procedure. In this way, together with existing literature compounds, a more complete library of D-ring modified $(S)$-blebbistatin analogs was obtained for thorough structure-activity and structure-property analysis. We evaluated the myosin II inhibitory properties of the new analogs and the literature derivatives in an ATPase assay with 
rabbit skeletal muscle myosin II. The thus obtained SAR information revealed that large groups in the 3'- and/or 4'-position present potential bottlenecks for inhibitor design. In all, D-ring substitution does not lead to significant potency enhancement, but is useful to finetune the physicochemical profile of $(S)$-blebbistatin $(S)$-1. We were able to quantify for the first time the photosensitivity of $(S)$-blebbistatin $(S)-\mathbf{1}$ and confirmed that research applications requiring blue light irradiation are best conducted with $(S)$-4'-nitroblebbistatin $(S)$-29. On the other hand, when solubility issues of $(S)$-blebbistatin $(S)$-1 pose a problem for read-outs in cell-based experiments, $(S)$-3'-hydroxyblebbistatin $(S)$-17, $(S)$-3'aminoblebbistatin $(S)$-18 or $(S)-4$ '-aminoblebbistatin $(S)$-31 should be used as alternatives. These compounds combine a 30-fold higher aqueous solubility with conservation of cell membrane permeability. From an economical point of view, $(S)$-3'-hydroxyblebbistatin $(S)-17$ is the best choice for these applications, as it is the most readily accessible.

\section{Materials and methods}

\subsection{In silico studies}

All in silico studies were performed using Molecular Operating Environment (MOE) 2015.10 (Chemical Computing Group) as molecular modelling software [42]. Analyses were conducted based on the co-crystal structure of Dictyostelium discoideum myosin II heavy chain and blebbistatin (PDB: 1YV3) [22]. Automated structure preparation was performed using standard parameters. Partial charges were automatically calculated. Minimizations were performed using an RMSD gradient of $0.001 \mathrm{Kcal} \mathrm{mol}^{-1} \AA^{-1}$ and the AMBER99 force field.

\subsection{Chemistry}

\subsubsection{General}

Dichloromethane was dried by heating under reflux over $\mathrm{CaH}_{2}$ and distilled under an atmosphere of nitrogen. Tetrahydrofuran was dried by heating under reflux with sodium/benzophenone under a nitrogen atmosphere and collected by distillation. Dry 1,4dioxane was purchased from Sigma-Aldrich. Dry acetonitrile, dry methanol and dry $\mathrm{N}, \mathrm{N}$-dimethylformamide were purchased from Acros Organics. Reagents were purchased at the highest commercial quality and were used as received without further purification. 
Yields refer to chromatographically and spectroscopically $\left({ }^{1} \mathrm{H}\right.$ NMR) homogeneous material, unless otherwise stated.

Reactions were monitored on an Agilent 1200 series HPLC system fitted with an Ascentis ${ }^{\circledR}$ Express C18-column (2.7 $\mu \mathrm{m}$ particle size, $4.6 \mathrm{~mm}$ internal diameter), using acetonitrile/water (5 $\mathrm{mM} \mathrm{NH}_{4} \mathrm{OAc}$ ) as eluent. Low-resolution mass spectra were recorded on an Agilent 1100 series VL mass spectrometer (ESI, $70 \mathrm{eV}$ ). High-resolution mass spectra (HRMS) were recorded using an Agilent Technologies 6210 series time-of-flight (TOF) or Thermo Scientific MAT95XP-Trap mass spectrometer. Thin layer chromatography (TLC) was carried out on $0.25 \mathrm{~mm}$ Merck silica plates $\left(60 \mathrm{~F}_{254}\right)$ and spots were visualized by UV light $(254 \mathrm{~nm})$. Flash column chromatography was performed on an automated Reveleris ${ }^{\circledR}$ X1 flash chromatography system, using Reveleris ${ }^{\circledR}$ C18 or Reveleris ${ }^{\circledR}$ silica cartridges. Melting points were determined using a Wagner \& Munz WME Heizbank Kofler bench.

NMR spectra were recorded on a Bruker Avance III instrument. ${ }^{1} \mathrm{H}$ NMR (400 MHz) chemical shifts are recorded in $\mathrm{CDCl}_{3}, \mathrm{DMSO}-\mathrm{d}_{6}$ or $\mathrm{CD}_{3} \mathrm{OD}$, reported in ppm and measured relative to tetramethylsilane or the residual undeuterated solvent as the internal reference, respectively. ${ }^{13} \mathrm{C}$ NMR $(100.6 \mathrm{MHz})$ chemical shifts are reported in ppm and were measured relative to the residual solvent as the internal reference. The following abbreviations were used to explain NMR peak multiplicities: $\mathrm{s}=$ singlet, $\mathrm{d}=$ doublet, $\mathrm{t}=$ triplet, $\mathrm{q}=$ quartet, $\mathrm{p}=$ pentet, $\mathrm{m}=$ multiplet, $\mathrm{br}=$ broad.

Infrared spectroscopy was performed on a Shimadzu IRAFFINITY-1S WL spectrophotometer with an ATR (Attenuated Total Reflectance) accessory. Samples were analyzed in neat form and selected peaks are reported.

The enantiomeric excess (ee) of chiral compounds was determined via chiral HPLC analysis using a Daicel Chiralpak IA column ( $5 \mu \mathrm{m}$ particle size, $150 \mathrm{~mm}$ length, $2.1 \mathrm{~mm}$ internal diameter). Detection wavelength was set at $268 \mathrm{~nm}$. Analyses under reversed phase and normal phase conditions were performed at $25^{\circ} \mathrm{C}$ and $35^{\circ} \mathrm{C}$, respectively. Optical rotations were obtained on a Jasco P-2000 polarimeter and are reported in deg $\mathrm{mL} \mathrm{g}^{-1} \mathrm{dm}^{-1}$; concentrations are reported in grams per $100 \mathrm{~mL}$.

Tris(3,5-dimethyl-1H-pyrazol-1-yl)methane and compounds $(S)-\mathbf{1},(S)-\mathbf{2},(S)-\mathbf{7}, \mathbf{2 2}, \mathbf{1 4 a},(S)$ 17 and $(S)$-18 were prepared as described earlier [19]. Acrylic anhydride was synthesized according to the procedure of Jian et al. [24]. Amidine $\mathbf{1 4 g}$ was prepared as reported by 
Képiró et al. [17]. Compounds 19b and 24 were synthesized according to the procedure of Myochin et al. [29]. Pyrrolidinone 21a was prepared as described by Tye et al. [43]. Compounds 21d and $\mathbf{2 8}$ have been previously prepared by Sedlák et al. [44] and Twibanire et al. [45], respectively.

\subsubsection{General procedure for the esterification of phenols using acid chlorides}

In a flame-dried bulb of $50 \mathrm{~mL}$, phenol ( $0.489 \mathrm{mmol}, 1$ equiv) was dissolved in $25 \mathrm{~mL}$ of dry acetonitrile. The reaction mixture was cooled to $0{ }^{\circ} \mathrm{C}$, after which $0.167 \mathrm{~g}$ of $\mathrm{Cs}_{2} \mathrm{CO}_{3}$ ( $0.511 \mathrm{mmol}, 1.05$ equiv), $0.0119 \mathrm{~g}$ of 4-dimethylaminopyridine ( $0.0973 \mathrm{mmol}, 0.2$ equiv) and acid chloride ( $0.632 \mathrm{mmol}, 1.3$ equiv) were added sequentially. Then, the reaction mixture was stirred for 30 minutes at room temperature under a nitrogen atmosphere. Afterwards, the mixture was evaporated in vacuo, diluted with $150 \mathrm{~mL}$ of ethyl acetate and washed with saturated aqueous $\mathrm{NH}_{4} \mathrm{Cl}(2 \times 50 \mathrm{~mL})$. The organic layer was dried over magnesium sulfate and evaporated in vacuo.

4.2.2.1. (S)-3-(3a-hydroxy-6-methyl-4-oxo-2,3,3a,4-tetrahydro-1H-pyrrolo[2,3-b]quinolin-1yl)phenyl acrylate ((S)-3)

(S)-3'-acryloxyblebbistatin (S)-3 was synthesized from $(S)$-3'-hydroxyblebbistatin $(S)-\mathbf{1 7}$ ( $0.150 \mathrm{~g}, 0.487 \mathrm{mmol}, 1$ equiv) and acryloyl chloride $(51.5 \mu \mathrm{L}, 0.633 \mathrm{mmol}, 1.3$ equiv). Evaporation in vacuo afforded an orange oil $(0.161 \mathrm{~g})$ which was dissolved in dichloromethane and coated onto silica under reduced pressure. Subsequently, purification was performed via automated flash chromatography with hexane/ethyl acetate as eluent on a Reveleris ${ }^{\circledR} 12 \mathrm{~g}$ silica cartridge (1\% sample loading; flow rate: $36 \mathrm{~mL} \mathrm{~min}^{-1}$; eluent: $2 \mathrm{CV}$ of $6 \%$ ethyl acetate, followed by a gradient from $6 \%$ to $60 \%$ ethyl acetate over $30 \mathrm{CV}$; detection wavelengths: $220 \mathrm{~nm}$ and $270 \mathrm{~nm})$. This resulted in $(S)-3$ '-acryloxyblebbistatin $(S)-3(0.107 \mathrm{~g}$, $61 \%$ ) as a yellow powder. The enantiomeric excess was $>99 \%$ as determined by chiral HPLC analysis (Daicel Chiralpak IA column, acetonitrile/water (50:50), $1.0 \mathrm{~mL} \mathrm{~min}^{-1}, 25^{\circ} \mathrm{C}$ ). Mp $178{ }^{\circ} \mathrm{C} . \quad R_{\mathrm{f}}=0.51 \quad$ (hexane/ethyl acetate, 1:1). Ee $>99 \%$, chiral HPLC: $t_{\mathrm{R}}((S)-$ 3) $=7.63 \mathrm{~min}, t_{\mathrm{R}}((R)-3)=8.85 \mathrm{~min}$ (Daicel Chiralpak IA column, acetonitrile/water (50:50),

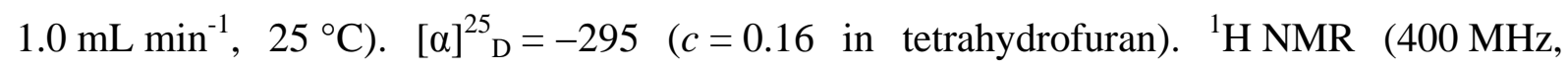
DMSO-d $\left.)^{6}\right): \delta=2.21-2.36(5 \mathrm{H}, \mathrm{m}), 3.93-4.10 \quad(2 \mathrm{H}, \mathrm{m}), 6.19 \quad\left(1 \mathrm{H}, \mathrm{dd}, J_{l}=10.2 \mathrm{~Hz}\right.$, $\left.J_{2}=1.1 \mathrm{~Hz}\right), 6.46\left(1 \mathrm{H}, \mathrm{dd}, J_{l}=17.4 \mathrm{~Hz}, J_{2}=10.2 \mathrm{~Hz}\right), 6.58 \quad\left(1 \mathrm{H}, \quad \mathrm{dd}, \quad J_{l}=17.4 \mathrm{~Hz}\right.$, $\left.J_{2}=1.1 \mathrm{~Hz}\right), 6.89(1 \mathrm{H}, \mathrm{s}), 6.97\left(1 \mathrm{H}, \mathrm{dd}, J_{1}=8.1 \mathrm{~Hz}, J_{2}=2.1 \mathrm{~Hz}\right), 7.13(1 \mathrm{H}, \mathrm{d}, J=8.2 \mathrm{~Hz})$, 
$7.39\left(1 \mathrm{H}, \mathrm{dd}, J_{l}=8.2 \mathrm{~Hz}, J_{2}=1.6 \mathrm{~Hz}\right), 7.48\left(1 \mathrm{H}, \mathrm{dd}, J_{1}=8.3 \mathrm{~Hz}, J_{2}=8.1 \mathrm{~Hz}\right), 7.55(1 \mathrm{H}, \mathrm{d}$, $J=1.6 \mathrm{~Hz}), 7.94\left(1 \mathrm{H}, \mathrm{dd}, J_{l}=8.3 \mathrm{~Hz}, J_{2}=2.0 \mathrm{~Hz}\right), 8.10\left(1 \mathrm{H}, \mathrm{dd}, J_{l}=2.1 \mathrm{~Hz}, J_{2}=2.0 \mathrm{~Hz}\right)$. ${ }^{13} \mathrm{C}$ NMR (100.6 MHz, DMSO-d $\left.{ }^{6}\right): \delta=20.7,28.6,48.0,73.3,113.3,117.1,121.5,126.5$, 126.8, 128.2, 130.0, 133.1, 134.2, 136.9, 142.0, 149.1, 150.8, 164.6, 165.8, 194.9. IR (ATR, $\left.\mathrm{cm}^{-1}\right): v_{\max }=802,1022,1146,1221,1589,1692,1734 . \mathrm{MS}(\mathrm{ESI}): \mathrm{m} / \mathrm{z}(\%)=362.5\left([\mathrm{M}+\mathrm{H}]^{+}\right.$, 100). HRMS (ESI): calculated for $\mathrm{C}_{21} \mathrm{H}_{19} \mathrm{~N}_{2} \mathrm{O}_{4}\left([\mathrm{M}+\mathrm{H}]^{+}\right)$363.1339; found 363.1345 . $\mathrm{MW}=362.39 .{ }^{1} \mathrm{H}$ NMR spectrum, ${ }^{13} \mathrm{C}$ NMR spectrum and chiral HPLC chromatograms are provided in Figures S5-S6 and S44-S45 in the Supporting Information.

4.2.2.2. (S)-3-(3a-hydroxy-6-methyl-4-oxo-2,3,3a,4-tetrahydro-1H-pyrrolo[2,3-b]quinolin-1yl)phenyl propionate $((S)-4)$

(S)-3'-propionyloxyblebbistatin (S)-4 was synthesized from $(S)$-3'-hydroxyblebbistatin $(S)-17$ $(0.150 \mathrm{~g}, 0.487 \mathrm{mmol}, 1$ equiv) and propionyl chloride $(59.5 \mu \mathrm{L}, 0.682 \mathrm{mmol}, 1.4$ equiv). Evaporation in vacuo afforded $(S)$-3'-propionyloxyblebbistatin $(S)-\mathbf{4}$ as a bright yellow powder $(0.176 \mathrm{~g}, 99 \%)$. The enantiomeric excess was $99 \%$ as determined by chiral HPLC analysis (Daicel Chiralpak IA column, acetonitrile/water (40:60), $1.0 \mathrm{~mL} \mathrm{~min}^{-1}, 25^{\circ} \mathrm{C}$ ). M.p. $176{ }^{\circ}$ C. $\quad R_{\mathrm{f}}=0.53$ (hexane/ethyl acetate, 1:1). Ee 99\%, chiral HPLC: $t_{\mathrm{R}}((S)-$ 4) $=16.4 \mathrm{~min}, t_{\mathrm{R}}((R)-4)=20.8 \mathrm{~min}$ (Daicel Chiralpak IA column, acetonitrile/water (40:60), $\left.1.0 \mathrm{~mL} \mathrm{~min}^{-1}, 25{ }^{\circ} \mathrm{C}\right) .[\alpha]_{\mathrm{D}}^{25}=-290 \quad(c=0.13$ in tetrahydrofuran $) .{ }^{1} \mathrm{H} \mathrm{NMR}(400 \mathrm{MHz}$, DMSO-d $\left.{ }^{6}\right): \delta=1.16(3 \mathrm{H}, \mathrm{t}, J=7.5 \mathrm{~Hz}), 2.21-2.36(5 \mathrm{H}, \mathrm{m}), 2.65(2 \mathrm{H}, \mathrm{q}, J=7.5 \mathrm{~Hz}), 3.92-$ $4.10(2 \mathrm{H}, \mathrm{m}), 6.88(1 \mathrm{H}, \mathrm{s}), 6.91\left(1 \mathrm{H}, \mathrm{dd}, J_{1}=8.1 \mathrm{~Hz}, J_{2}=2.0 \mathrm{~Hz}\right), 7.14(1 \mathrm{H}, \mathrm{d}, J=8.0 \mathrm{~Hz})$, $7.40\left(1 \mathrm{H}, \mathrm{dd}, J_{l}=8.0 \mathrm{~Hz}, J_{2}=1.6 \mathrm{~Hz}\right), 7.45\left(1 \mathrm{H}, \mathrm{dd}, J_{1}=8.3 \mathrm{~Hz}, J_{2}=8.1 \mathrm{~Hz}\right), 7.55(1 \mathrm{H}, \mathrm{d}$, $J=1.6 \mathrm{~Hz}), 7.90\left(1 \mathrm{H}, \mathrm{dd}, J_{1}=8.3 \mathrm{~Hz}, J_{2}=1.9 \mathrm{~Hz}\right), 8.05\left(1 \mathrm{H}, \mathrm{dd}, J_{l}=2.0 \mathrm{~Hz}, J_{2}=1.9 \mathrm{~Hz}\right)$. ${ }^{13} \mathrm{C}$ NMR (100.6 MHz, DMSO-d $\left.{ }^{6}\right): \delta=9.4,20.7,27.4,28.6,48.0,73.3,113.5,116.9,117.3$, $121.5,126.5,126.8,129.9,133.1,136.9,142.0,149.2,151.1,165.8,173.1,194.9$. IR (ATR, $\left.\mathrm{cm}^{-1}\right): v_{\max }=791,1096,1134,1593,1684,1755,3420 . \mathrm{MS}(\mathrm{ESI}): \mathrm{m} / \mathrm{z}(\%)=364.6\left([\mathrm{M}+\mathrm{H}]^{+}\right.$, 100). HRMS (ESI): calculated for $\mathrm{C}_{21} \mathrm{H}_{21} \mathrm{~N}_{2} \mathrm{O}_{4}\left([\mathrm{M}+\mathrm{H}]^{+}\right)$365.1496; found 365.1502 . $\mathrm{MW}=364.40$. ${ }^{1} \mathrm{H}$ NMR spectrum, ${ }^{13} \mathrm{C}$ NMR spectrum and chiral HPLC chromatograms are provided in Figures S7-S8 and S46-S47 in the Supporting Information.

4.2.3. General procedure for the amidation of anilines using acid anhydrides

The selective mono-amidation of anilines was adopted from a publication of Jahani et al. [23]. 
In a bulb of $10 \mathrm{~mL}$ containing $3 \mathrm{~mL}$ of absolute ethanol, $0.0028 \mathrm{~g}$ of guanidine hydrochloride (0.0293 mmol, 0.15 equiv), acid anhydride (0.197 mmol, 1.01 equiv) and aniline ( 0.195 mmol, 1 equiv) were brought together under a nitrogen atmosphere. The reaction mixture was heated to $40{ }^{\circ} \mathrm{C}$ and stirred for 30 minutes. Next, the mixture was diluted with $75 \mathrm{~mL}$ of ethyl acetate and washed with saturated aqueous $\mathrm{NaHCO}_{3}(2 \times 40 \mathrm{~mL})$ and brine (30 mL). The organic layer was dried over magnesium sulfate and evaporated in vacuo.

\subsubsection{1. (S)-N-(3-(3a-hydroxy-6-methyl-4-oxo-2,3,3a,4-tetrahydro-1H-pyrrolo[2,3-b]quinolin-} 1-yl)phenyl)acrylamide ((S)-5)

$(S)$-3'-acrylamidoblebbistatin $(S)$-5 was synthesized from $(S)$-3'-aminoblebbistatin $(S)$-18 (0.0600 g, $0.195 \mathrm{mmol}, 1$ equiv) and acrylic anhydride $(22.7 \mu \mathrm{L}, 0.197 \mathrm{mmol}, 1.01$ equiv). Evaporation in vacuo afforded a yellow powder $(0.0670 \mathrm{~g})$ which was dissolved in acetone and further purified via preparative TLC with hexane/ethyl acetate (2:3) as eluent. This resulted in $(S)$-3' -acrylamidoblebbistatin $(S)-5(0.0515 \mathrm{~g}, 73 \%)$ as an orange powder. The enantiomeric excess was $99 \%$ as determined by chiral HPLC analysis (Daicel Chiralpak IA column, hexane/dichloromethane/absolute ethanol (10:90:3), $\left.0.5 \mathrm{~mL} \mathrm{~min}^{-1}, \quad 35^{\circ} \mathrm{C}\right)$. M.p. $236{ }^{\circ}$ C. $\quad R_{\mathrm{f}}=0.21$ (hexane/ethyl acetate, 2:3). Ee 99\%, chiral HPLC: $t_{\mathrm{R}}((S)-$ 5) $=24.2 \mathrm{~min}, \quad t_{\mathrm{R}}((R)-5)=11.1 \mathrm{~min} \quad($ Daicel Chiralpak IA column, hexane/dichloromethane/absolute ethanol (10:90:3), $\left.\quad 0.5 \mathrm{~mL} \mathrm{~min}^{-1}, \quad 35{ }^{\circ} \mathrm{C}\right) . \quad{ }^{1} \mathrm{H} \mathrm{NMR}$ $\left(400 \mathrm{MHz}\right.$, DMSO-d $\left.{ }^{6}\right): \delta=2.22-2.37,3.89-3.99,3.99-4.10,5.78\left(1 \mathrm{H}, \mathrm{dd}, J_{l}=10.0 \mathrm{~Hz}\right.$, $\left.J_{2}=1.9 \mathrm{~Hz}\right), 6.29\left(1 \mathrm{H}, \quad \mathrm{dd}, J_{1}=17.0 \mathrm{~Hz}, \quad J_{2}=1.9 \mathrm{~Hz}\right), 6.49 \quad\left(1 \mathrm{H}, \quad \mathrm{dd}, \quad J_{l}=17.0 \mathrm{~Hz}\right.$, $\left.J_{2}=10.0 \mathrm{~Hz}\right), 6.85(1 \mathrm{H}, \mathrm{s}), 7.17(1 \mathrm{H}, \mathrm{d}, J=7.9 \mathrm{~Hz}), 7.37\left(1 \mathrm{H}, \mathrm{dd}, J_{1}=8.2 \mathrm{~Hz}, J_{2}=8.1 \mathrm{~Hz}\right)$, $7.40\left(1 \mathrm{H}, \mathrm{dd}, J_{1}=7.9 \mathrm{~Hz}, J_{2}=1.7 \mathrm{~Hz}\right), 7.48-7.56(1 \mathrm{H}, \mathrm{m}), 7.54(1 \mathrm{H}, \mathrm{d}, J=1.7 \mathrm{~Hz}), 7.80(1 \mathrm{H}$, $\left.\mathrm{dd}, J_{1}=8.2 \mathrm{~Hz}, J_{2}=1.8 \mathrm{~Hz}\right), 8.43\left(1 \mathrm{H}, \mathrm{dd}, J_{l}=2.0 \mathrm{~Hz}, J_{2}=1.8 \mathrm{~Hz}\right), 10.22(1 \mathrm{H}$, br. s). ${ }^{13} \mathrm{C}$ NMR (100.6 MHz, DMSO-d $\left.\mathrm{d}^{6}\right): \delta=20.7,28.8,48.0,73.3,111.3,115.2,115.4,121.5$, $126.5,126.8,127.4,129.4,132.4,132.8,136.9,139.8,141.3,149.5,163.7,165.7,195.0$. IR $\left(\right.$ ATR, $\left.\mathrm{cm}^{-1}\right): v_{\max }=781,797,1238,1476,1589,1667,1684 . \mathrm{MS}(\mathrm{ESI}): \mathrm{m} / \mathrm{z}(\%)=361.5$ $\left([\mathrm{M}+\mathrm{H}]^{+}\right.$, 100). HRMS (ESI): calculated for $\mathrm{C}_{21} \mathrm{H}_{20} \mathrm{~N}_{3} \mathrm{O}_{3}\left([\mathrm{M}+\mathrm{H}]^{+}\right)$362.1499; found 362.1497. $\mathrm{MW}=361.39$. ${ }^{1} \mathrm{H} \mathrm{NMR}$ spectrum, ${ }^{13} \mathrm{C} \mathrm{NMR}$ spectrum and chiral HPLC chromatograms are provided in Figures S9-S10 and S48-S49 in the Supporting Information.

4.2.3.2. (S)-N-(3-(3a-hydroxy-6-methyl-4-oxo-2,3,3a,4-tetrahydro-1H-pyrrolo[2,3-b]quinolin1-yl)phenyl)propionamide ((S)-6) 
(S)-3'-propionylamidoblebbistatin $(S)$-6 was synthesized from $(S)$-3'-aminoblebbistatin $(S)-\mathbf{1 8}$ (0.0600 g, $0.195 \mathrm{mmol}, 1$ equiv) and propionic anhydride $(25.3 \mu \mathrm{L}, 0.197 \mathrm{mmol}, 1.01$ equiv). Evaporation in vacuo afforded $(S)$-3'-propionylamidoblebbistatin $(S)-6(0.0648 \mathrm{~g}, 91 \%)$ as an orange powder. The enantiomeric excess was $>99 \%$ as determined by chiral HPLC analysis (Daicel Chiralpak IA column, hexane/dichloromethane/absolute ethanol (10:90:3), $\left.0.5 \mathrm{~mL} \min ^{-1}, 35^{\circ} \mathrm{C}\right)$. M.p. $220^{\circ} \mathrm{C}$. Ee $>99 \%$, chiral HPLC: $t_{\mathrm{R}}((S)-6)=17.4 \mathrm{~min}, t_{\mathrm{R}}((R)-$ 6) $=9.37 \mathrm{~min}$ (Daicel Chiralpak IA column, hexane/dichloromethane/absolute ethanol (10:90:3), $\left.0.5 \mathrm{~mL} \mathrm{~min}^{-1}, \quad 35^{\circ} \mathrm{C}\right) . \quad[\alpha]_{\mathrm{D}}^{25}=-306$ (c=0.21 in tetrahydrofuran). ${ }^{1} \mathrm{H} \mathrm{NMR}$ $\left(400 \mathrm{MHz}, \mathrm{DMSO}-\mathrm{d}^{6}\right): \delta=1.11(3 \mathrm{H}, \mathrm{t}, J=7.5 \mathrm{~Hz}), 2.22-2.30(2 \mathrm{H}, \mathrm{m}), 2.31(3 \mathrm{H}, \mathrm{s}), 2.36$ $(2 \mathrm{H}, \mathrm{q}, J=7.5 \mathrm{~Hz}), 3.88-3.96(1 \mathrm{H}, \mathrm{m}), 3.97-4.08(1 \mathrm{H}, \mathrm{m}), 6.84(1 \mathrm{H}, \mathrm{s}), 7.16(1 \mathrm{H}, \mathrm{d}$, $J=8.1 \mathrm{~Hz}), 7.32(1 \mathrm{H}, \mathrm{t}, J=8.1 \mathrm{~Hz}), 7.39\left(1 \mathrm{H}, \mathrm{dd}, J_{1}=8.1 \mathrm{~Hz}, J_{2}=1.9 \mathrm{~Hz}\right), 7.41-7.47(1 \mathrm{H}$, m), $7.54(1 \mathrm{H}, \mathrm{d}, J=1.9 \mathrm{~Hz}), 7.74-7.80(1 \mathrm{H}, \mathrm{m}), 8.33(1 \mathrm{H}, \mathrm{t}, J=1.9 \mathrm{~Hz}), 9.93(1 \mathrm{H}$, br. s). ${ }^{13} \mathrm{C}$ NMR (100.6 MHz, DMSO-d $\left.{ }^{6}\right): \delta=10.1,20.7,28.8,30.0,48.0,73.3,110.9,114.9,114.9$, $121.5,126.4,126.8,129.2,132.7,136.9,140.2,141.2,149.6,165.7,172.5,195.1$. IR (ATR, $\left.\mathrm{cm}^{-1}\right): \quad v_{\max }=775,1107,1238,1458,1595,1622,1668,3260,3341$. MS (ESI): $\mathrm{m} / \mathrm{z}(\%)=363.5\left([\mathrm{M}+\mathrm{H}]^{+}, \quad 100\right)$. HRMS (ESI): calculated for $\mathrm{C}_{21} \mathrm{H}_{22} \mathrm{~N}_{3} \mathrm{O}_{3} \quad\left([\mathrm{M}+\mathrm{H}]^{+}\right)$ 364.1656; found 364.1661. MW = 363.41. ${ }^{1} \mathrm{H}$ NMR spectrum, ${ }^{13} \mathrm{C}$ NMR spectrum and chiral HPLC chromatograms are provided in Figures S11-S12 and S50-S51 in the Supporting Information.

\subsubsection{1-(4-(Allyloxy)phenyl)pyrrolidin-2-one (21c)}

The $N$-arylation of 2-pyrrolidinone (20) with aryl iodide 28 was based on Haldón et al. [26]

In a flame-dried bulb of $250 \mathrm{~mL}$, containing $60 \mathrm{~mL}$ of dry 1,4-dioxane, $0.595 \mathrm{~g}$ of $\mathrm{CuI}$ (3.12 mmol, $\quad 0.05$ equiv) and $\quad 0.929 \mathrm{~g}$ of tris(3,5-dimethyl- $1 H$-pyrazol-1-yl)methane (3.12 mmol, 0.05 equiv) were brought together under a nitrogen atmosphere. Then, $16.2 \mathrm{~g}$ of aryl iodide 28 (62.3 mmol, 1 equiv), $5.69 \mathrm{~mL}$ of 2-pyrrolidinone (20) (74.8 mmol, 1.2 equiv) and $26.5 \mathrm{~g}$ of $\mathrm{K}_{3} \mathrm{PO}_{4}(125 \mathrm{mmol}, 2$ equiv) were added and the reaction mixture was stirred at reflux temperature for 24 hours. Next, the suspension was cooled down to room temperature and the solids were filtered off on a sintered glass Büchner funnel. The filter cake was rinsed with ethyl acetate until the filtrate turned colorless. The filtrate was washed with an equal volume of $3 \mathrm{M}$ aqueous $\mathrm{HCl}(3 \times)$ and brine, after which the organic layer was dried over magnesium sulfate. Evaporation in vacuo afforded an orange solid (24.2 g) of which $12.1 \mathrm{~g}$ was dissolved in dichloromethane and coated under reduced pressure onto silica. 
Subsequently, purification was performed via automated flash chromatography with hexane/ethyl acetate as eluent on a Reveleris ${ }^{\circledR} 120 \mathrm{~g}$ cartridge (10\% sample loading; flow rate: $80 \mathrm{~mL} \mathrm{~min}^{-1}$; eluent: $2 \mathrm{CV}$ of $20 \%$ ethyl acetate, followed by a gradient from $20 \%$ to $100 \%$ ethyl acetate over $20 \mathrm{CV}$; detection wavelengths: $234 \mathrm{~nm}$ and $250 \mathrm{~nm}$ ). The same conditions were applied to purify the other half of the crude mixture. Evaporation of the combined fractions resulted in pyrrolidinone 21c $(10.2 \mathrm{~g}, 75 \%)$ as a white powder. M.p. $104{ }^{\circ} \mathrm{C} . R_{\mathrm{f}}=0.16$ (hexane/ethyl acetate, $\left.1: 1\right) .{ }^{1} \mathrm{H} \mathrm{NMR}\left(400 \mathrm{MHz}, \mathrm{CDCl}_{3}\right): \delta=2.15(2 \mathrm{H}$, p, $J=7.6 \mathrm{~Hz}), 2.59(2 \mathrm{H}, \mathrm{t}, J=7.6 \mathrm{~Hz}), 3.83(2 \mathrm{H}, \mathrm{t}, J=7.6 \mathrm{~Hz}), 4.53\left(2 \mathrm{H}, \mathrm{ddd}, J_{l}=5.3 \mathrm{~Hz}\right.$, $\left.J_{2}=1.5 \mathrm{~Hz}, J_{3}=1.4 \mathrm{~Hz}\right), 5.28\left(1 \mathrm{H}, \mathrm{ddd}, J_{1}=10.5 \mathrm{~Hz}, J_{2}=1.5 \mathrm{~Hz}, J_{3}=1.4 \mathrm{~Hz}\right), 5.41(1 \mathrm{H}, \mathrm{dq}$, $\left.J_{l}=17.3 \mathrm{~Hz}, J_{2}=1.5 \mathrm{~Hz}\right), 6.05\left(1 \mathrm{H}, \mathrm{ddt}, J_{1}=17.3 \mathrm{~Hz}, J_{2}=10.5 \mathrm{~Hz}, J_{3}=5.3 \mathrm{~Hz}\right), 6.89-6.94$ (2H, m), 7.46-7.52 (2H, m). $\left.{ }^{13} \mathrm{C} \mathrm{NMR} \mathrm{(100.6} \mathrm{MHz,} \mathrm{CDCl}_{3}\right): \delta=18.1,32.5,49.2,69.1,115.0$, 117.7, 121.7, 132.8, 133.2, 155.6, 173.9. IR (ATR, $\left.\mathrm{cm}^{-1}\right): v_{\max }=827,1018,1225,1508,1680$. MS (ESI): $\mathrm{m} / \mathrm{z}(\%)=218.2\left([\mathrm{M}+\mathrm{H}]^{+}, 100\right)$. HRMS (ESI): calculated for $\mathrm{C}_{13} \mathrm{H}_{16} \mathrm{NO}_{2}\left([\mathrm{M}+\mathrm{H}]^{+}\right)$ 218.1176; found 218.1178. $\mathrm{MW}=217.26$. ${ }^{1} \mathrm{H}$ NMR and ${ }^{13} \mathrm{C} \mathrm{NMR}$ spectra are provided in Figures S16-S17 in the Supporting Information.

4.2.5. General procedure for the $N$-arylation of 2-pyrrolidinone (20) with aryl bromides

The $N$-arylation of 2-pyrrolidinone (20) with aryl bromides was based on a procedure of Klapars et al. [28]

In a flame-dried bulb of $100 \mathrm{~mL}$ containing $60 \mathrm{~mL}$ of dry 1,4-dioxane, $0.238 \mathrm{~g}$ of $\mathrm{CuI}$ (1.25 mmol, 0.05 equiv) and $269 \mu \mathrm{L}$ of $N, N^{\prime}$-dimethylethylenediamine $(2.50 \mathrm{mmol}$, 0.1 equiv) were brought together under a nitrogen atmosphere. Then, aryl bromide (25.0 mmol, 1 equiv), $2.28 \mathrm{~mL}$ of 2-pyrrolidinone (20) (30.0 mmol, 1.2 equiv) and $6.91 \mathrm{~g}$ of $\mathrm{K}_{2} \mathrm{CO}_{3}$ (50.0 mmol, 2 equiv) were added and the reaction mixture was stirred at reflux temperature for 23 hours. Next, a second portion of $\mathrm{CuI}(0.238 \mathrm{~g}, 1.25 \mathrm{mmol}, 0.05$ equiv) and of $N, N^{\prime}$-dimethylethylenediamine $(269 \mu \mathrm{L}, 2.50 \mathrm{mmol}, 0.1$ equiv) were added and the mixture was stirred for 8 hours at reflux temperature. The resulting suspension was cooled down to room temperature and the solids were filtered off on a sintered glass Büchner funnel. The filter cake was rinsed with $150 \mathrm{~mL}$ of ethyl acetate. The filtrate was washed with saturated aqueous $\mathrm{NH}_{4} \mathrm{Cl}(3 \times 60 \mathrm{~mL})$ and brine $(60 \mathrm{~mL})$, after which the organic layer was dried over magnesium sulfate and evaporated in vacuo.

\subsubsection{1-(1-Allylindolin-6-yl)pyrrolidin-2-one (21b)}


Pyrrolidinone 21b was synthesized from aryl bromide 19b (9.53 g, $40.0 \mathrm{mmol}, 1$ equiv) and 2-pyrrolidinone $(\mathbf{2 0})(3.65 \mathrm{~mL}, 48.0 \mathrm{mmol}, 1.2$ equiv). Evaporation in vacuo afforded pyrrolidinone 21b $(9.60 \mathrm{~g}, 99 \%)$ as a yellow-orange oil. ${ }^{1} \mathrm{H} \mathrm{NMR}\left(400 \mathrm{MHz}, \mathrm{CDCl}_{3}\right)$ : $\delta=2.12(2 \mathrm{H}, \mathrm{p}, J=7.5 \mathrm{~Hz}), 2.58(2 \mathrm{H}, \mathrm{t}, J=7.5 \mathrm{~Hz}), 2.92(2 \mathrm{H}, \mathrm{t}, J=8.3 \mathrm{~Hz}), 3.36(2 \mathrm{H}, \mathrm{t}$, $J=8.3 \mathrm{~Hz}), 3.72\left(2 \mathrm{H}, \mathrm{ddd}, J_{l}=6.0 \mathrm{~Hz}, J_{2}=1.4 \mathrm{~Hz}, J_{3}=1.3 \mathrm{~Hz}\right), 3.82(2 \mathrm{H}, \mathrm{t}, J=7.5 \mathrm{~Hz})$, $5.19\left(1 \mathrm{H}, \quad \mathrm{ddd}, J_{l}=10.2 \mathrm{~Hz}, J_{2}=1.5 \mathrm{~Hz}, J_{3}=1.3 \mathrm{~Hz}\right), 5.28\left(1 \mathrm{H}, \quad \mathrm{ddd}, J_{l}=17.1 \mathrm{~Hz}\right.$, $\left.J_{2}=1.5 \mathrm{~Hz}, J_{3}=1.4 \mathrm{~Hz}\right), 5.90\left(1 \mathrm{H}, \mathrm{ddt}, J_{l}=17.1 \mathrm{~Hz}, J_{2}=10.2 \mathrm{~Hz}, J_{3}=6.0 \mathrm{~Hz}\right), 6.67(1 \mathrm{H}$, $\left.\mathrm{dd}, J_{l}=7.9 \mathrm{~Hz}, J_{2}=1.9 \mathrm{~Hz}\right), 6.92(1 \mathrm{H}, \mathrm{d}, J=1.9 \mathrm{~Hz}), 7.02(1 \mathrm{H}, \mathrm{d}, J=7.9 \mathrm{~Hz}) .{ }^{13} \mathrm{C} \mathrm{NMR}$ $\left(100.6 \mathrm{MHz}, \mathrm{CDCl}_{3}\right): \delta=18.1,28.0,32.8,49.5,51.8,53.5,100.5,109.4,117.4,124.1,126.9$, 133.9, 139.0, 152.7, 174.0. MS (ESI): $\mathrm{m} / \mathrm{z}(\%)=243.1\left([\mathrm{M}+\mathrm{H}]^{+}, 100\right) . \quad \mathrm{MW}=242.32$. ${ }^{1} \mathrm{H}$ NMR and ${ }^{13} \mathrm{C}$ NMR spectra are provided in Figures S19-S20 in the Supporting Information.

\subsubsection{General procedure for the synthesis of amidines from pyrrolidinones}

The preparation of amidines was adopted from Verhasselt et al. [19].

A flame-dried bulb of $250 \mathrm{~mL}$, kept under a nitrogen atmosphere, was loaded with $120 \mathrm{~mL}$ of dry dichloromethane and pyrrolidinone $\left(43.9 \mathrm{mmol}, 1\right.$ equiv). Next, $8.18 \mathrm{~mL}$ of $\mathrm{POCl}_{3}$ (87.7 mmol, 2 equiv) was added and the resulting mixture was stirred at room temperature for 24 hours. Afterwards, a solution of methyl 2-amino-5-methylbenzoate (22) (7.61 g, $46.0 \mathrm{mmol}, 1.05$ equiv) in dry dichloromethane $(45 \mathrm{~mL})$ was added via cannula and the reaction mixture was heated to $35^{\circ} \mathrm{C}$ for 24 hours. Then, the reaction mixture was cooled to $0{ }^{\circ} \mathrm{C}$, basified with $3 \mathrm{M}$ aqueous $\mathrm{NaOH}$ until the $\mathrm{pH}$ equaled 10 and subsequently extracted with ethyl acetate $(450 \mathrm{~mL}$ and $150 \mathrm{~mL})$. The combined organic layers were washed with $300 \mathrm{~mL}$ of brine, dried over magnesium sulfate and evaporated in vacuo.

\subsubsection{Methyl 5-methyl-2-((1-(naphthalen-2-yl)pyrrolidin-2-ylidene)amino)benzoate (14d)}

Amidine 14d was synthesized from pyrrolidinone 21a (3.80 g, $18.0 \mathrm{mmol}, 1$ equiv) and methyl 2-amino-5-methylbenzoate (22) (3.12 g, 18.9 mmol, 1.05 equiv). Evaporation in vacuo afforded an orange-brown oil ( $8.54 \mathrm{~g}$ ) which was dissolved in acetonitrile/dichloromethane (1:1) and coated under reduced pressure onto $17.1 \mathrm{~g}$ of Davisil® C18 silica. Subsequently, purification was performed via automated flash chromatography with water/acetonitrile as eluent on a Reveleris ${ }^{\circ} 120 \mathrm{~g} \mathrm{C} 18$ cartridge (7\% sample loading; flow rate: $80 \mathrm{~mL} \mathrm{~min}{ }^{-1}$; eluent: $2 \mathrm{CV}$ of $30 \%$ acetonitrile, followed by a gradient from $30 \%$ to $80 \%$ acetonitrile over 
$20 \mathrm{CV}$ and finally $2 \mathrm{CV}$ of $80 \%$ acetonitrile; detection wavelength: $216 \mathrm{~nm}$ and $244 \mathrm{~nm}$ ). Evaporation of the combined fractions afforded amidine 14d (3.12 g, 48\%) as an off-white powder. M.p. $132{ }^{\circ} \mathrm{C} .{ }^{1} \mathrm{H} \mathrm{NMR}\left(400 \mathrm{MHz}, \mathrm{CDCl}_{3}\right): \delta=2.10(2 \mathrm{H}, \mathrm{p}, J=7.3 \mathrm{~Hz}), 2.33(3 \mathrm{H}, \mathrm{s})$, $2.51(2 \mathrm{H}, \mathrm{t}, J=7.3 \mathrm{~Hz}), 3.84(3 \mathrm{H}, \mathrm{s}), 3.99(2 \mathrm{H}, \mathrm{t}, J=7.3 \mathrm{~Hz}), 6.74(1 \mathrm{H}, \mathrm{d}, J=8.1 \mathrm{~Hz}), 7.19$ $\left(1 \mathrm{H}, \mathrm{dd}, J_{l}=8.1 \mathrm{~Hz}, J_{2}=1.7 \mathrm{~Hz}\right), 7.33-7.39(1 \mathrm{H}, \mathrm{m}), 7.39-7.45(1 \mathrm{H}, \mathrm{m}), 7.67(1 \mathrm{H}, \mathrm{d}$, $J=1.7 \mathrm{~Hz}), 7.73-7.81(2 \mathrm{H}, \mathrm{m}), 7.80(1 \mathrm{H}, \mathrm{d}, J=9.0 \mathrm{~Hz}), 7.91(1 \mathrm{H}, \mathrm{d}, J=1.8 \mathrm{~Hz}), 8.31(1 \mathrm{H}$, $\left.\mathrm{dd}, J_{1}=9.0 \mathrm{~Hz}, J_{2}=1.8 \mathrm{~Hz}\right) .{ }^{13} \mathrm{C} \mathrm{NMR}\left(100.6 \mathrm{MHz}, \mathrm{CDCl}_{3}\right): \delta=19.8,20.6,29.1,50.9,51.8$, $116.4,121.3$, 122.0, 123.1, 124.5, 126.0, 127.4, 127.5, 128.1, 130.1, 131.1, 133.5, 133.8, 139.4, 150.6, 159.9, 167.8. IR (ATR, $\mathrm{cm}^{-1}$ ): $v_{\max }=1200,1304,1396,1626,1653,1717 . \mathrm{MS}$ (ESI): $\mathrm{m} / \mathrm{z}(\%)=359.2\left([\mathrm{M}+\mathrm{H}]^{+}, 100\right) . \mathrm{MW}=358.44 .{ }^{1} \mathrm{H} \mathrm{NMR}$ and ${ }^{13} \mathrm{C} \mathrm{NMR}$ spectra are provided in Figures S22-S23 in the Supporting Information.

\subsubsection{Methyl 2-((1-(1-allylindolin-6-yl)pyrrolidin-2-ylidene)amino)-5-methylbenzoate (14e)}

Amidine 14e was synthesized from pyrrolidinone $21 \mathbf{b}(9.59 \mathrm{~g}, 39.6 \mathrm{mmol}, 1$ equiv) and methyl 2-amino-5-methylbenzoate (22) (6.54 g, 41.6 mmol, 1.05 equiv). Evaporation in vacuo afforded a dark red oil (19.5 g) of which $6.50 \mathrm{~g}$ was dissolved in dichloromethane and coated under reduced pressure onto $13.0 \mathrm{~g}$ of Davisil ${ }^{\circledR}$ C18 silica. Subsequently, purification was performed via automated flash chromatography with water/acetonitrile as eluent on a Reveleris ${ }^{\circledR} 120$ g C18 cartridge (5\% sample loading; flow rate: $80 \mathrm{~mL} \mathrm{~min}^{-1}$; eluent: $2 \mathrm{CV}$ of $50 \%$ acetonitrile, a gradient from $50 \%$ to $60 \%$ acetonitrile over $20 \mathrm{CV}$, a gradient from $60 \%$ to $100 \%$ acetonitrile over $10 \mathrm{CV}$, and finally $2 \mathrm{CV}$ of $100 \%$ acetonitrile; detection wavelength: $218 \mathrm{~nm}$ and $314 \mathrm{~nm}$ ). Next, the same conditions were repeated twice to purify the remaining parts of the crude mixture. Evaporation of the combined fractions afforded amidine $14 \mathrm{e}(6.49 \mathrm{~g}, 42 \%)$ as an orange oil. $R_{\mathrm{f}}=0.22$ (hexane/ethyl acetate, 1:1). ${ }^{1} \mathrm{H}$ NMR $\left(400 \mathrm{MHz}, \mathrm{CDCl}_{3}\right): \delta=2.00(2 \mathrm{H}, \mathrm{p}, J=7.3 \mathrm{~Hz}), 2.31(3 \mathrm{H}, \mathrm{s}), 2.44(2 \mathrm{H}, \mathrm{t}, J=7.3 \mathrm{~Hz}), 2.89$ $(2 \mathrm{H}, \mathrm{t}, J=8.2 \mathrm{~Hz}), 3.32(2 \mathrm{H}, \mathrm{t}, J=8.2 \mathrm{~Hz}), 3.70\left(2 \mathrm{H}, \mathrm{ddd}, J_{l}=6.1 \mathrm{~Hz}, J_{2}=1.4 \mathrm{~Hz}\right.$, $\left.J_{3}=1.3 \mathrm{~Hz}\right), 3.81(3 \mathrm{H}, \mathrm{s}), 3.82(2 \mathrm{H}, \mathrm{t}, J=7.3 \mathrm{~Hz}), 5.15\left(1 \mathrm{H}, \mathrm{ddd}, J_{l}=10.4 \mathrm{~Hz}, J_{2}=1.5 \mathrm{~Hz}\right.$, $\left.J_{3}=1.3 \mathrm{~Hz}\right), 5.26\left(1 \mathrm{H}, \mathrm{ddd}, J_{1}=17.0 \mathrm{~Hz}, J_{2}=1.5 \mathrm{~Hz}, J_{3}=1.4 \mathrm{~Hz}\right), 5.90(1 \mathrm{H}, \quad \mathrm{ddt}$, $\left.J_{l}=17.0 \mathrm{~Hz}, J_{2}=10.4 \mathrm{~Hz}, J_{3}=6.1 \mathrm{~Hz}\right), 6.69(1 \mathrm{H}, \mathrm{d}, J=8.1 \mathrm{~Hz}), 6.88\left(1 \mathrm{H}, \mathrm{dd}, J_{1}=7.9 \mathrm{~Hz}\right.$, $\left.J_{2}=1.6 \mathrm{~Hz}\right), 7.01(1 \mathrm{H}, \mathrm{d}, J=7.9 \mathrm{~Hz}), 7.16\left(1 \mathrm{H}, \mathrm{dd}, J_{1}=8.1 \mathrm{~Hz}, J_{2}=2.0 \mathrm{~Hz}\right), 7.19(1 \mathrm{H}, \mathrm{d}$, $J=1.6 \mathrm{~Hz}), 7.62(1 \mathrm{H}, J=2.0 \mathrm{~Hz}) .{ }^{13} \mathrm{C} \mathrm{NMR}\left(100.6 \mathrm{MHz}, \mathrm{CDCl}_{3}\right): \delta=19.9,20.6,28.1,29.1$, 51.4, 51.7, 52.1, 53.6, 101.6, 110.3, 117.2, 122.1, 123.2, 124.0, 125.5, 130.7, 130.9, 133.3, 134.4, 141.1, 151.0, 152.5, 159.7, 168.0. IR (ATR, $\left.\mathrm{cm}^{-1}\right): v_{\max }=1491,1501,1611,1659$, 
1722. MS (ESI): $\mathrm{m} / \mathrm{z}(\%)=390.2\left([\mathrm{M}+\mathrm{H}]^{+}, 100\right) . \mathrm{MW}=389.50 .{ }^{1} \mathrm{H} \mathrm{NMR}$ and ${ }^{13} \mathrm{C} \mathrm{NMR}$ spectra are provided in Figures S24-S25 in the Supporting Information.

\subsubsection{Methyl 2-((1-(4-(allyloxy)phenyl)pyrrolidin-2-ylidene)amino)-5-methylbenzoate (14f)}

Amidine 14f was synthesized from pyrrolidinone 21c $(9.53 \mathrm{~g}, 43.9 \mathrm{mmol}, 1$ equiv) and methyl 2-amino-5-methylbenzoate (22) (7.61 g, $46.0 \mathrm{mmol}, 1.05$ equiv). Evaporation in vacuo afforded an orange-brown oil $(15.5 \mathrm{~g})$ of which $7.75 \mathrm{~g}$ was dissolved in acetonitrile/dichloromethane (1:1) and coated under reduced pressure onto $15.5 \mathrm{~g}$ of Davisil® C18 silica. Subsequently, purification was performed via automated flash chromatography with water/acetonitrile as eluent on a Reveleris ${ }^{\circ} 120 \mathrm{~g} \mathrm{C18}$ cartridge (6\% sample loading; flow rate: $80 \mathrm{~mL} \mathrm{~min}^{-1}$; eluent: $2 \mathrm{CV}$ of $30 \%$ acetonitrile, followed by a gradient from $30 \%$ to $100 \%$ acetonitrile over $20 \mathrm{CV}$ and finally $2 \mathrm{CV}$ of $100 \%$ acetonitrile; detection wavelength: $214 \mathrm{~nm}$ ). The same conditions were applied to purify the other half of the crude mixture. Evaporation of the combined fractions afforded amidine $\mathbf{1 4 f}(12.5 \mathrm{~g}, 78 \%)$ as an orange oil. $R_{\mathrm{f}}=0.38$ (hexane/ethyl acetate/triethylamine, 7:3:0.5). ${ }^{1} \mathrm{H}$ NMR $\left(400 \mathrm{MHz}, \mathrm{CDCl}_{3}\right): \delta=2.02$ $(2 \mathrm{H}, \mathrm{p}, J=7.3 \mathrm{~Hz}), 2.31(3 \mathrm{H}, \mathrm{s}), 2.43(2 \mathrm{H}, \mathrm{t}, J=7.3 \mathrm{~Hz}), 3.82(3 \mathrm{H}, \mathrm{s}), 3.82(2 \mathrm{H}, \mathrm{t}$, $J=7.3 \mathrm{~Hz}), 4.51\left(2 \mathrm{H}, \mathrm{ddd}, J_{1}=5.3 \mathrm{~Hz}, J_{2}=1.5 \mathrm{~Hz}, J_{3}=1.4 \mathrm{~Hz}\right), 5.26\left(1 \mathrm{H}, \mathrm{ddd}, J_{1}=10.5 \mathrm{~Hz}\right.$, $\left.J_{2}=1.5 \mathrm{~Hz}, \quad J_{3}=1.4 \mathrm{~Hz}\right), \quad 5.39\left(1 \mathrm{H}, \quad \mathrm{dq}, \quad J_{1}=17.2 \mathrm{~Hz}, \quad J_{2}=1.5 \mathrm{~Hz}\right), 6.04 \quad(1 \mathrm{H}, \quad \mathrm{ddt}$, $\left.J_{l}=17.2 \mathrm{~Hz}, J_{2}=10.5 \mathrm{~Hz}, J_{3}=5.3 \mathrm{~Hz}\right), 6.70(1 \mathrm{H}, \mathrm{d}, J=8.1 \mathrm{~Hz}), 6.88-6.94(2 \mathrm{H}, \mathrm{m}), 7.16$ $\left(1 \mathrm{H}, \mathrm{dd}, J_{l}=8.1 \mathrm{~Hz}, J_{2}=1.8 \mathrm{~Hz}\right), 7.63(1 \mathrm{H}, \mathrm{d}, J=1.8 \mathrm{~Hz}), 7.66-7.72(2 \mathrm{H}, \mathrm{m}) .{ }^{13} \mathrm{C} \mathrm{NMR}$ (100.6 MHz, $\left.\mathrm{CDCl}_{3}\right): \delta=19.8,20.6,29.0,51.0,51.7,69.1,114.9,117.5,122.1,122.2,123.3$, $130.8,131.0,133.4,133.5,135.0,150.9,154.6,159.8,167.9$. IR $\left(\right.$ ATR, $\left.\mathrm{cm}^{-1}\right): v_{\max }=1244$, 1404, 1512, 1659, 1722. MS (ESI): m/z $(\%)=365.3\left([\mathrm{M}+\mathrm{H}]^{+}, 100\right)$. HRMS (ESI): calculated for $\mathrm{C}_{22} \mathrm{H}_{25} \mathrm{~N}_{2} \mathrm{O}_{3}\left([\mathrm{M}+\mathrm{H}]^{+}\right)$365.1860; found 365.1868. MW = 364.44. ${ }^{1} \mathrm{H} \mathrm{NMR}$ and ${ }^{13} \mathrm{C} \mathrm{NMR}$ spectra are provided in Figures S26-S27 in the Supporting Information.

4.2.7. General procedure for the one-pot synthesis of $\alpha$-hydroxy ketones from amidines

An oven-dried bulb of $100 \mathrm{~mL}$, degassed and back-filled with argon (5x), was loaded with $30 \mathrm{~mL}$ of dry tetrahydrofuran and $2.15 \mathrm{~g}$ of amidine ( $6.00 \mathrm{mmol}, 1$ equiv). Then, the solution was cooled to $-78{ }^{\circ} \mathrm{C}$ and $12.6 \mathrm{~mL}$ of lithiumbis(trimethylsilyl)amide $(1 \mathrm{M}$ solution in tetrahydrofuran, $12.6 \mathrm{mmol}, 2.1$ equiv) was added, after which the mixture was stirred at $0{ }^{\circ} \mathrm{C}$ for 1.5 hours. Afterwards, the reaction was cooled to $-78{ }^{\circ} \mathrm{C}$ and a solution of $(-)-(8,8-$ dichlorocamphorylsulfonyl)oxaziridine (16) (4.29 g, $14.4 \mathrm{mmol}, 2.4$ equiv) in dry 
tetrahydrofuran $(34 \mathrm{~mL})$ was added via cannula. Subsequently, the mixture was stirred at $-15^{\circ} \mathrm{C}$ for 16 hours before being quenched by the addition of $350 \mathrm{~mL}$ of saturated aqueous $\mathrm{NH}_{4} \mathrm{Cl}$. The reaction mixture was extracted with diethyl ether $(3 \times 440 \mathrm{~mL})$ and the combined organic extracts were concentrated to a volume of $220 \mathrm{~mL}$ and subsequently washed with $0.3 \mathrm{M}$ aqueous $\mathrm{HCl}(3 \times 240 \mathrm{~mL})$. The combined aqueous layers were washed with $180 \mathrm{~mL}$ of hexane, basified with $3 \mathrm{M}$ aqueous $\mathrm{NaOH}$ until $\mathrm{pH} 10$ was reached and extracted with ethyl acetate $(2 \times 1000 \mathrm{~mL})$. The combined organic extracts were dried with magnesium sulfate and evaporated in vacuo.

4.2.7.1. (S)-3a-hydroxy-6-methyl-1-phenyl-1,2,3,3a-tetrahydro-4H-pyrrolo[2,3-b]quinolin-4one $((S)-1)$

$(S)$-blebbistatin $(S)$-1 was synthesized from amidine 14a $(0.167 \mathrm{~g}, 0.500 \mathrm{mmol}, 1$ equiv). Evaporation in vacuo afforded $(S)-\mathbf{1}(0.146 \mathrm{~g}$, quant) as an ochreous powder. The enantiomeric excess was $86 \%$ as determined by chiral HPLC analysis (Daicel Chiralpak IA column, acetonitrile/water (50:50), $\left.1.0 \mathrm{~mL} \mathrm{~min}^{-1}, 25^{\circ} \mathrm{C}\right)$.

4.2.7.2. (S)-3a-hydroxy-6-methyl-1-(naphthalen-2-yl)-1,2,3,3a-tetrahydro-4H-pyrrolo[2,3b]quinolin-4-one ((S)-9)

(S)-benzo[c']blebbistatin (S)-9 was synthesized from amidine 14d $(2.15 \mathrm{~g}, 6.00 \mathrm{mmol}$, 1 equiv). Evaporation in vacuo afforded $(S)-9(1.03 \mathrm{~g}, 50 \%)$ as a yellow powder. The enantiomeric excess was $72 \%$ as determined by chiral HPLC analysis (Daicel Chiralpak IA column, acetonitrile/water (50:50), $\left.1.0 \mathrm{~mL} \mathrm{~min}^{-1}, 25^{\circ} \mathrm{C}\right)$. The powder was redissolved in $175 \mathrm{~mL}$ of boiling acetonitrile and left untouched for 30 minutes at room temperature. This resulted in $(S)$-benzo[c']blebbistatin $(S)$-9 $(0.546 \mathrm{~g}, 26 \%)$ as bright yellow crystals with an enantiomeric excess of $>99 \%$. M.p. $246{ }^{\circ} \mathrm{C}$. Ee $>99 \%$, chiral HPLC: $t_{\mathrm{R}}((S)-9)=16.6$ min, $t_{\mathrm{R}}((R)-9)=22.1 \mathrm{~min}$ (Daicel Chiralpak IA column, acetonitrile/water (50:50), $1.0 \mathrm{~mL} \mathrm{~min}^{-1}$, $\left.25^{\circ} \mathrm{C}\right) . \quad[\alpha]^{25} \mathrm{D}=-486 \quad\left(c=0.10\right.$ in tetrahydrofuran). ${ }^{1} \mathrm{H} \mathrm{NMR} \quad\left(400 \mathrm{MHz}\right.$, DMSO-d $\left.\mathrm{d}^{6}\right)$ : $\delta=2.27-2.40(2 \mathrm{H}, \mathrm{m}), 2.33(3 \mathrm{H}, \mathrm{s}), 4.08-4.24(2 \mathrm{H}, \mathrm{m}), 6.90(1 \mathrm{H}, \mathrm{s}), 7.20(1 \mathrm{H}, \mathrm{d}, J=8.1 \mathrm{~Hz})$, $7.41\left(1 \mathrm{H}, \mathrm{dd}, J_{l}=8.1 \mathrm{~Hz}, J_{2}=1.8 \mathrm{~Hz}\right), 7.43-7.49(1 \mathrm{H}, \mathrm{m}), 7.50-7.56(1 \mathrm{H}, \mathrm{m}), 7.56(1 \mathrm{H}, \mathrm{d}$, $J=1.8 \mathrm{~Hz}), 7.88-7.95(2 \mathrm{H}, \mathrm{m}), 7.97(1 \mathrm{H}, \mathrm{d}, J=9.0 \mathrm{~Hz}), 8.42(1 \mathrm{H}, \mathrm{d}, J=2.1 \mathrm{~Hz}), 8.51(1 \mathrm{H}$, $\left.\mathrm{dd}, J_{1}=9.0 \mathrm{~Hz}, J_{2}=2.1 \mathrm{~Hz}\right) .{ }^{13} \mathrm{C}$ NMR $\left(100.6 \mathrm{MHz}, \mathrm{DMSO}-\mathrm{d}^{6}\right): \delta=20.7,28.8,48.2,73.4$, $116.6,120.4,121.5,125.5,126.5,126.8,127.0,127.9,128.1,128.6,130.2$, 132.9, 133.7, 137.0, 138.9, 149.5, 165.8, 195.0. IR (ATR, $\left.\mathrm{cm}^{-1}\right): v_{\max }=737,800,1587,1605,1695 . \mathrm{MS}$ 
(ESI): $\mathrm{m} / \mathrm{z}(\%)=343.1\left([\mathrm{M}+\mathrm{H}]^{+}, 100\right)$. HRMS (ESI): calculated for $\mathrm{C}_{22} \mathrm{H}_{19} \mathrm{~N}_{2} \mathrm{O}_{2}\left([\mathrm{M}+\mathrm{H}]^{+}\right)$ 343.1441; found 343.1451. MW $=342.40 .{ }^{1} \mathrm{H}$ NMR spectrum, ${ }^{13} \mathrm{C}$ NMR spectrum and chiral HPLC chromatograms are provided in Figures S29-S30 and S52-S53 in the Supporting Information.

4.2.7.3. (S)-1-(4-(allyloxy)phenyl)-3a-hydroxy-6-methyl-1,2,3,3a-tetrahydro-4H-pyrrolo[2,3b]quinolin-4-one ((S)-12)

$(S)$-4'-allyloxyblebbistatin $(S)$-12 was synthesized from amidine $\mathbf{1 4 f}(2.50 \mathrm{~g}, 6.86 \mathrm{mmol}$, 1 equiv). Evaporation in vacuo afforded $(S)-\mathbf{1 2}(1.03 \mathrm{~g}, 43 \%)$ as a bright yellow powder. The enantiomeric excess was $82 \%$ as determined by chiral HPLC analysis (Daicel Chiralpak IA column, acetonitrile/water (50:50), $\left.1.0 \mathrm{~mL} \mathrm{~min}^{-1}, 25^{\circ} \mathrm{C}\right)$. The powder was redissolved in $9 \mathrm{~mL}$ of boiling acetonitrile and left untouched for 7 minutes at room temperature. After 2 minutes crystals had formed, which were filtered off after an additional 5 minutes. This resulted in $(S)$-4' -allyloxyblebbistatin $(S)$-12 $(0.474 \mathrm{~g}, 20 \%)$ as bright yellow crystals with an enantiomeric excess of $>99 \%$. M.p. $192{ }^{\circ} \mathrm{C}$. Ee $>99 \%$, chiral HPLC: $t_{\mathrm{R}}((S)-\mathbf{1 2})=13.7 \mathrm{~min}$, $t_{\mathrm{R}}((R)-\mathbf{1 2})=22.5 \mathrm{~min}$ (Daicel Chiralpak IA column, acetonitrile/water (50:50), $1.0 \mathrm{~mL} \mathrm{~min}{ }^{-1}$, $\left.25{ }^{\circ} \mathrm{C}\right) . \quad[\alpha]^{25}=-452 \quad\left(c=0.18\right.$ in tetrahydrofuran). ${ }^{1} \mathrm{H}$ NMR $\left(400 \mathrm{MHz}\right.$, DMSO-d $\left.\mathrm{d}^{6}\right)$ : $\delta=2.22-2.28(2 \mathrm{H}, \mathrm{m}), 2.30(3 \mathrm{H}, \mathrm{s}), 3.88-3.95(1 \mathrm{H}, \mathrm{m}), 4.00-4.09(1 \mathrm{H}, \mathrm{m}), 4.59(2 \mathrm{H}, \mathrm{ddd}$, $\left.J_{1}=5.2 \mathrm{~Hz}, J_{2}=1.6 \mathrm{~Hz}, J_{3}=1.5 \mathrm{~Hz}\right), 5.28\left(1 \mathrm{H}, \mathrm{ddd}, J_{1}=10.5 \mathrm{~Hz}, J_{2}=1.6 \mathrm{~Hz}, J_{3}=1.5 \mathrm{~Hz}\right)$, $5.42\left(1 \mathrm{H}, \mathrm{dq}, J_{l}=17.3 \mathrm{~Hz}, J_{2}=1.6 \mathrm{~Hz}\right), 6.06\left(1 \mathrm{H}, \mathrm{ddt}, J_{l}=17.3 \mathrm{~Hz}, J_{2}=10.5 \mathrm{~Hz}\right.$, $\left.J_{3}=5.2 \mathrm{~Hz}\right), 6.79(1 \mathrm{H}, \mathrm{s}), 6.99-7.05(2 \mathrm{H}, \mathrm{m}), 7.07(1 \mathrm{H}, \mathrm{d}, J=8.1 \mathrm{~Hz}), 7.35(1 \mathrm{H}, \mathrm{dd}$, $\left.J_{l}=8.1 \mathrm{~Hz}, J_{2}=2.1 \mathrm{~Hz}\right), 7.52(1 \mathrm{H}, \mathrm{d}, J=2.1 \mathrm{~Hz}), 7.94-8.00(2 \mathrm{H}, \mathrm{m}) .{ }^{13} \mathrm{C} \mathrm{NMR}(100.6 \mathrm{MHz}$, DMSO-d $\left.{ }^{6}\right): \delta=20.7,29.0,48.2,68.8,73.4,115.1,117.9,121.4,121.7,126.1,126.8,132.2$, 134.3, 134.4, 136.9, 150.0, 154.9, 165.3, 195.1. IR (ATR, $\left.\mathrm{cm}^{-1}\right): v_{\max }=800,827,937,995$, 1107, 1595, 1688. MS (ESI): $\mathrm{m} / \mathrm{z}(\%)=349.3\left([\mathrm{M}+\mathrm{H}]^{+}, 100\right)$. HRMS (ESI): calculated for $\mathrm{C}_{21} \mathrm{H}_{21} \mathrm{~N}_{2} \mathrm{O}_{3} \quad\left([\mathrm{M}+\mathrm{H}]^{+}\right) \quad 349.1547$; found 349.1549. MW = 348.40. ${ }^{1} \mathrm{H} \mathrm{NMR}$ spectrum, ${ }^{13} \mathrm{C}$ NMR spectrum and chiral HPLC chromatograms are provided in Figures S31-S32 and S54-S55 in the Supporting Information.

4.2.7.4. (S)-3a-hydroxy-6-methyl-1-(4-nitrophenyl)-1,2,3,3a-tetrahydro-4H-pyrrolo[2,3b]quinolin-4-one ((S)-29) [17]

(S)-4'-nitroblebbistatin (S)-29 was synthesized from amidine $\mathbf{1 4 g}(1.15 \mathrm{~g}, 3.25 \mathrm{mmol}$, 1 equiv). Evaporation in vacuo afforded an orange oil (1.09 g), containing $40 \mathrm{~m} \%$ of $(S)-4$ '- 
nitroblebbistatin $(S)-29$ and $60 \mathrm{~m} \%$ of dimer 30, which was dissolved in tetrahydrofuran and coated under reduced pressure onto silica. Subsequently, purification was performed via automated flash chromatography with hexane/ethyl acetate as eluent on a Reveleris ${ }^{\circledR} 120 \mathrm{~g}$ silica cartridge ( $1 \%$ sample loading; flow rate: $80 \mathrm{~mL} \mathrm{~min}^{-1}$; eluent: $2 \mathrm{CV}$ of $0 \%$ ethyl acetate, followed by a gradient from $0 \%$ to $40 \%$ ethyl acetate over $30 \mathrm{CV}$; detection wavelengths: $260 \mathrm{~nm}$ and $368 \mathrm{~nm})$. This resulted in $(S)-4$ '-nitroblebbistatin $(S)-29(0.416 \mathrm{~g}, 38 \%)$ as an orange powder. The enantiomeric excess was $82 \%$ as determined by chiral HPLC analysis analysis (Daicel Chiralpak IA column, acetonitrile/water (50:50), $1.0 \mathrm{~mL} \mathrm{~min}^{-1}, 25^{\circ} \mathrm{C}$ ). The powder was redissolved in $25 \mathrm{~mL}$ of boiling acetonitrile and left untouched for 19 hours at room temperature. This resulted in $(S)$-4'-nitroblebbistatin $(S)$-29 $(0.248 \mathrm{~g}, 20 \%)$ as orange crystals with an enantiomeric excess of $>99 \% . R_{\mathrm{f}}=0.32$ (hexane/ethyl acetate, $1: 1$ ). Ee $>99 \%$, chiral HPLC: $t_{\mathrm{R}}((S)-29)=16.6 \mathrm{~min}, t_{\mathrm{R}}((R)-29)=32.1 \mathrm{~min}$ (Daicel Chiralpak IA column, acetonitrile/water (50:50), $\left.1.0 \mathrm{~mL} \mathrm{~min}^{-1}, 25^{\circ} \mathrm{C}\right) .{ }^{1} \mathrm{H}$ NMR $\left(400 \mathrm{MHz}, \mathrm{DMSO}-\mathrm{d}^{6}\right): \delta=2.25-$ $2.40(2 \mathrm{H}, \mathrm{m}), 2.34(3 \mathrm{H}, \mathrm{s}), 4.03-4.15(2 \mathrm{H}, \mathrm{m}), 6.97(1 \mathrm{H}, \mathrm{s}), 7.24(1 \mathrm{H}, \mathrm{d}, J=8.1 \mathrm{~Hz}), 7.45$ $\left(1 \mathrm{H}, \mathrm{dd}, J_{1}=8.1 \mathrm{~Hz}, J_{2}=1.8 \mathrm{~Hz}\right), 7.59(1 \mathrm{H}, \mathrm{d}, J=1.8 \mathrm{~Hz}), 8.28-8.34(2 \mathrm{H}, \mathrm{m}), 8.36-8.42$ $(2 \mathrm{H}, \mathrm{m}) . \mathrm{MW}=337.34 .{ }^{1} \mathrm{H}$ NMR spectrum and chiral HPLC chromatograms are provided in Figures S33 and S56-S57 in the Supporting Information.

4.2.8. (S)-3a-hydroxy-1-(indolin-6-yl)-6-methyl-1,2,3,3a-tetrahydro-4H-pyrrolo[2,3b]quinolin-4-one $((S)-8)$

Amidine 14e (2.64 g, $6.77 \mathrm{mmol}, 1$ equiv) was converted via the general procedure for the one-pot synthesis of $\alpha$-hydroxy ketones from amidines. Evaporation in vacuo afforded an orange-brown powder $(1.29 \mathrm{~g})$, containing $86 \%(\mathrm{~m} / \mathrm{m})$ of compound $(S)-25$ and $14 \%(\mathrm{~m} / \mathrm{m})$ of molecule $(S)$-26. The enantiomeric excess of $(S)$-25 in this mixture was $80 \%$ as determined by chiral HPLC analysis (Daicel Chiralpak IA column, acetonitrile/water (60:40), $1.0 \mathrm{~mL} \mathrm{~min}^{-1}$, $25^{\circ} \mathrm{C}$ ). The powder was redissolved in $50 \mathrm{~mL}$ of boiling absolute ethanol and left untouched for 19 hours at room temperature. This afforded dark yellow-brown fibers $(0.212 \mathrm{~g})$, containing $91 \%(\mathrm{~m} / \mathrm{m})$ of $(S)-\mathbf{2 5}$ and $9 \%(\mathrm{~m} / \mathrm{m})$ of $(S)-\mathbf{2 6}$, with an enantiomeric excess of $>99 \%$. Chiral HPLC chromatograms are provided in Figures S57-S58 in the Supporting Information.

In a flame-dried bulb of $50 \mathrm{~mL}$ containing $15 \mathrm{~mL}$ of dry dichloromethane, $0.210 \mathrm{~g}$ of the $(S)$ 25/(S)-26 (91:9) mixture ( $0.512 \mathrm{mmol}$ of $(S)$-25, 1 equiv), $0.479 \mathrm{~g}$ of $N, N$ '-dimethylbarbituric acid (3.07 mmol, 6 equiv) and $0.0590 \mathrm{~g}$ of tetrakis(triphenylphosphine)palladium $(0)$ 
( $0.0512 \mathrm{mmol}, 0.1$ equiv) were brought together under a nitrogen atmosphere and stirred for 1 hour at reflux temperature. Afterwards, the reaction mixture was cooled to room temperature, diluted with $90 \mathrm{~mL}$ of ethyl acetate and washed with saturated aqueous $\mathrm{NaHCO}_{3}(2 \times 30 \mathrm{~mL})$. The organic layer was dried over magnesium sulfate and evaporated in vacuo. This resulted in an orange-brown powder $(0.354 \mathrm{~g})$ which was dissolved in tetrahydrofuran and coated under reduced pressure onto silica. Subsequently, purification was performed via automated flash chromatography with hexane/ethyl acetate as eluent on a Reveleris ${ }^{\circledR} 40 \mathrm{~g}$ silica cartridge (1\% sample loading; flow rate: $40 \mathrm{~mL} \mathrm{~min}$; eluent: $2 \mathrm{CV}$ of $20 \%$ ethyl acetate, followed by a gradient from $20 \%$ to $100 \%$ ethyl acetate over $20 \mathrm{CV}$; detection wavelengths: $220 \mathrm{~nm}$ and $250 \mathrm{~nm})$. This resulted in (S)-2,3-dihydro-1H-pyrrolo[2,3-c']blebbistatin $(S)-8(0.125 \mathrm{~g}, 73 \%)$ as an orange powder. The enantiomeric excess was $>99 \%$ as determined by chiral HPLC analysis analysis (Daicel Chiralpak IA column, acetonitrile/water (60:40), $1.0 \mathrm{~mL} \mathrm{~min}^{-1}$, $25^{\circ} \mathrm{C}$ ). $R_{\mathrm{f}}=0.22$ (hexane/ethyl acetate, $\left.1: 1\right)$. Ee $>99 \%$, chiral HPLC: $t_{\mathrm{R}}((S)-\mathbf{8})=4.93$ min, $t_{\mathrm{R}}((R)-8)=8.19 \mathrm{~min}$ (Daicel Chiralpak IA column, acetonitrile/water $(60: 40), 1.0 \mathrm{~mL} \mathrm{~min}^{-1}$, $\left.25{ }^{\circ} \mathrm{C}\right) .{ }^{1} \mathrm{H}$ NMR (400 MHz, DMSO-d $\left.{ }^{6}\right): \delta=2.18-2.25(2 \mathrm{H}, \mathrm{m}), 2.29(3 \mathrm{H}, \mathrm{s}), 2.90(2 \mathrm{H}, \mathrm{t}$, $J=8.4 \mathrm{~Hz}), 3.44(2 \mathrm{H}, \mathrm{t}, J=8.4 \mathrm{~Hz}), 3.82-3.89(2 \mathrm{H}, \mathrm{m}), 3.95-4.04(2 \mathrm{H}, \mathrm{m}), 5.64$ (1H, br. s), $6.78(1 \mathrm{H}, \mathrm{s}), 7.00-7.06(1 \mathrm{H}, \mathrm{m}), 7.03-7.07(2 \mathrm{H}, \mathrm{m}), 7.33-7.38(1 \mathrm{H}, \mathrm{m}), 7.36-7.38(1 \mathrm{H}, \mathrm{m})$, $7.51(1 \mathrm{H}, \mathrm{d}, J=1.8 \mathrm{~Hz}) .{ }^{13} \mathrm{C}$ NMR $\left(100.6 \mathrm{MHz}, \mathrm{DMSO}-\mathrm{d}^{6}\right): \delta=20.7,28.9,29.2,47.2,48.5$, 73.5, 101.5, 109.2, 121.3, 124.3, 125.1, 126.1, 126.7, 132.2, 136.9, 140.3, 150.1, 153.4, 165.5, 195.2. IR (ATR, $\left.\mathrm{cm}^{-1}\right): v_{\max }=1229,1479,1582,1599,1692 . \mathrm{MS}(\mathrm{ESI}): \mathrm{m} / \mathrm{z}(\%)=334.1$ $\left([\mathrm{M}+\mathrm{H}]^{+}\right.$, 100). HRMS (ESI): calculated for $\mathrm{C}_{20} \mathrm{H}_{20} \mathrm{~N}_{3} \mathrm{O}_{2}\left([\mathrm{M}+\mathrm{H}]^{+}\right)$334.1550; found 334.1554. $\mathrm{MW}=333.39 .{ }^{1} \mathrm{H} \mathrm{NMR}$ spectrum, ${ }^{13} \mathrm{C} \mathrm{NMR}$ spectrum and chiral HPLC chromatograms are provided in Figures S34-S35 and S60-S61 in the Supporting Information.

4.2.9. (S)-3a-hydroxy-1-(1H-indol-6-yl)-6-methyl-1,2,3,3a-tetrahydro-4H-pyrrolo[2,3$b]$ quinolin-4-one $((S)-\mathbf{1 0})$

Oxidation of $(S)$-2,3-dihydro-1H-pyrrolo[2,3-c']blebbistatin $(S)$-8 to $(S)$-1H-pyrrolo[2,3$c$ ']blebbistatin $(S)$-10 was based on a procedure reported by Reggelin et al. [46]

In a bulb of $50 \mathrm{~mL}, 0.105 \mathrm{~g}$ of $(S)-8(0.316 \mathrm{mmol}, 1$ equiv) was dissolved in $40 \mathrm{~mL}$ of chloroform, after which $0.312 \mathrm{~g}$ of $\mathrm{MnO}_{2}$ (88\%) (3.16 mmol, 10 equiv) was added, and the mixture was stirred for 3 hours at room temperature. Next, the solids were filtered off over celite and the filter cake was rinsed with $120 \mathrm{~mL}$ of tetrahydrofuran. Evaporation of the filtrate in vacuo afforded (S)-1H-pyrrolo[2,3-c']blebbistatin $(S)-\mathbf{1 0}(0.0729 \mathrm{~g}, 70 \%)$ as an 
orange powder. The enantiomeric excess was $>99 \%$ as determined by chiral HPLC analysis analysis (Daicel Chiralpak IA column, acetonitrile/water (60:40), $1.0 \mathrm{~mL} \mathrm{~min}^{-1}, 25^{\circ} \mathrm{C}$ ). M.p. $233{ }^{\circ} \mathrm{C}$. Ee $>99 \%$, chiral HPLC: $t_{\mathrm{R}}((S)-\mathbf{1 0})=4.52 \mathrm{~min}, t_{\mathrm{R}}((R)-\mathbf{1 0})=5.94 \mathrm{~min} \quad$ (Daicel Chiralpak IA column, acetonitrile/water $\left.(60: 40), 1.0 \mathrm{~mL} \mathrm{~min}^{-1}, 25^{\circ} \mathrm{C}\right) .[\alpha]^{25}{ }_{\mathrm{D}}=-578$ ( $c=0.10$ in tetrahydrofuran). ${ }^{1} \mathrm{H}$ NMR $\left(400 \mathrm{MHz}, \mathrm{DMSO}-\mathrm{d}^{6}\right): \delta=2.23-2.34(2 \mathrm{H}, \mathrm{m}, 2.30$ (3H, s), 3.94-4.04 (2H, m), 4.10-4.21 (2H, m), 6.40-6.45 (1H, m), $6.81(1 \mathrm{H}, \mathrm{s}), 7.07(1 \mathrm{H}, \mathrm{d}$, $J=8.1 \mathrm{~Hz}), 7.32-7.37(1 \mathrm{H}, \mathrm{m}), 7.33-7.40(1 \mathrm{H}, \mathrm{m}), 7.50-7.55(1 \mathrm{H}, \mathrm{m}), 7.50-7.55(1 \mathrm{H}, \mathrm{m})$, 8.23 (1H, br. s), 11.14 (1H, br. s). ${ }^{13} \mathrm{C}$ NMR (100.6 MHz, DMSO-d $\left.{ }^{6}\right): \delta=20.7,29.2,49.0$, 73.6, 101.4, 104.6, 113.2, 120.2, 121.4, 125.0, 126.0, 126.3, 126.8, 131.9, 135.1, 136.2, 136.9, 150.4, 165.6, 195.3. IR (ATR, $\left.\mathrm{cm}^{-1}\right): v_{\max }=799,833,1476,1595,1678,3244,3402$. MS (ESI): $\mathrm{m} / \mathrm{z}(\%)=332.1\left([\mathrm{M}+\mathrm{H}]^{+}, 100\right)$. HRMS (ESI): calculated for $\mathrm{C}_{20} \mathrm{H}_{18} \mathrm{~N}_{3} \mathrm{O}_{2}\left([\mathrm{M}+\mathrm{H}]^{+}\right)$ 332.1394; found 332.1396. $\mathrm{MW}=331.38$. ${ }^{1} \mathrm{H} \mathrm{NMR}$ spectrum, ${ }^{13} \mathrm{C}$ NMR spectrum and chiral HPLC chromatograms are provided in Figures S36-S37 and S62-S63 in the Supporting Information.

4.2.10. (S)-3a-hydroxy-1-(4-hydroxyphenyl)-6-methyl-1,2,3,3a-tetrahydro-4H-pyrrolo[2,3b]quinolin-4-one $((S)-\mathbf{1 1})$

The deprotection of $(S)$-4'-allyloxyblebbistatin $(S)$-12 to afford $(S)$-4'-hydroxyblebbistatin (S)-11 was based on a publication of Vutukuri et al. [47]

In a flame-dried bulb of $100 \mathrm{~mL}$, containing $40 \mathrm{~mL}$ of dry methanol, $0.294 \mathrm{~g}$ of $(S)-4^{\prime}-$ allyloxyblebbistatin $\quad(S)-\mathbf{1 2} \quad(0.842 \mathrm{mmol}, \quad 1$ equiv $)$ and $0.485 \mathrm{~g}$ of tetrakis(triphenylphosphine)palladium(0) $(0.0421 \mathrm{mmol}, 0.05$ equiv) were brought together under a nitrogen atmosphere and stirred for 5 minutes at room temperature. Then, $0.698 \mathrm{~g}$ of $\mathrm{K}_{2} \mathrm{CO}_{3}$ (5.05 mmol, 6 equiv) was added and the reaction mixture was stirred for 1.5 hours at $50{ }^{\circ} \mathrm{C}$. Afterwards, the mixture was concentrated to a volume of $5 \mathrm{~mL}$, diluted with $80 \mathrm{~mL}$ of ethyl acetate, washed with saturated aqueous $\mathrm{NH}_{4} \mathrm{Cl}(2 \times 15 \mathrm{~mL})$ and dried over magnesium sulfate. Evaporation in vacuo afforded bright orange fibers $(0.372 \mathrm{~g})$ which were dissolved in tetrahydrofuran and coated under reduced pressure onto silica. Subsequently, purification was performed via automated flash chromatography with hexane/ethyl acetate as eluent on a Reveleris ${ }^{\circledR} 40 \mathrm{~g}$ silica cartridge (1\% sample loading; flow rate: $40 \mathrm{~mL} \mathrm{~min}^{-1}$; eluent: $2 \mathrm{CV}$ of $16 \%$ ethyl acetate, followed by a gradient from $16 \%$ to $70 \%$ ethyl acetate over $25 \mathrm{CV}$; detection wavelengths: $220 \mathrm{~nm}$ and $262 \mathrm{~nm})$. This resulted in $(S)-4$ '-hydroxyblebbistatin $(S)$ $11(0.201 \mathrm{~g}, 77 \%)$ as a bright orange powder. The enantiomeric excess was $>99 \%$ as 
determined by chiral HPLC analysis of $(S)-4^{\prime}$-benzyloxyblebbistatin $(S)$-13. M.p. $224{ }^{\circ} \mathrm{C}$. $R_{\mathrm{f}}=0.30$ (hexane/ethyl acetate, 7:13). Ee $>99 \% .[\alpha]_{\mathrm{D}}^{25}=-473(c=0.13$ in tetrahydrofuran). ${ }^{1} \mathrm{H}$ NMR (400 MHz, $\left.\mathrm{CD}_{3} \mathrm{OD}\right): \delta=2.31-2.39$ (2H, m), $2.33(3 \mathrm{H}, \mathrm{s}), 3.87-3.95(1 \mathrm{H}, \mathrm{m}), 4.09-$ $4.17(1 \mathrm{H}, \mathrm{m}), 6.84-6.90(2 \mathrm{H}, \mathrm{m}), 7.08(1 \mathrm{H}, \mathrm{d}, J=8.2 \mathrm{~Hz}), 7.33\left(1 \mathrm{H}, \mathrm{dd}, J_{1}=8.2 \mathrm{~Hz}\right.$, $\left.J_{2}=2.2 \mathrm{~Hz}\right), 7.54-7.60(2 \mathrm{H}, \mathrm{m}), 7.62(1 \mathrm{H}, \mathrm{d}, J=2.2 \mathrm{~Hz}) .{ }^{13} \mathrm{C} \mathrm{NMR}\left(100.6 \mathrm{MHz}, \mathrm{CD}_{3} \mathrm{OD}\right)$ : $\delta=19.2,29.0,49.5,73.4,115.2,120.8,124.0,124.9,126.5,131.7,132.2,136.5,149.7,155.2$, 166.0, 195.2. IR $\left(\mathrm{ATR}, \mathrm{cm}^{-1}\right): v_{\max }=804,1209,1476,1584,1597,1665,3210,3591 . \mathrm{MS}$ $(E S I): m / z(\%)=309.2\left([M+H]^{+}, 100\right)$. HRMS (ESI): calculated for $\mathrm{C}_{18} \mathrm{H}_{17} \mathrm{~N}_{2} \mathrm{O}_{3}\left([\mathrm{M}+\mathrm{H}]^{+}\right)$ 309.1234; found 309.1234. $\mathrm{MW}=308.33$. ${ }^{1} \mathrm{H}$ NMR and ${ }^{13} \mathrm{C}$ NMR spectra are provided in Figures S38-S39 in the Supporting Information.

4.2.11. (S)-1-(4-(benzyloxy)phenyl)-3a-hydroxy-6-methyl-1,2,3,3a-tetrahydro-4Hpyrrolo[2,3-b]quinolin-4-one $((S)-\mathbf{1 3})$

In a flame-dried bulb of $10 \mathrm{~mL}, 0.0300 \mathrm{~g}$ of $(S)$-4'-hydroxyblebbistatin $(S)$-11 $(0.0973 \mathrm{mmol}$, 1 equiv) was dissolved in $5 \mathrm{~mL}$ of dry acetonitrile. The reaction mixture was cooled to $0{ }^{\circ} \mathrm{C}$, after which $0.0015 \mathrm{~g}$ of $\mathrm{NaI}\left(0.0097 \mathrm{mmol}, 0.1\right.$ equiv), $0.0333 \mathrm{~g}$ of $\mathrm{Cs}_{2} \mathrm{CO}_{3}(0.102 \mathrm{mmol}$, 1.05 equiv) and $12.1 \mu \mathrm{L}$ of benzyl bromide (0.102 mmol, 1.05 equiv) were added sequentially. Then, the reaction mixture was stirred for 1 hour at $50{ }^{\circ} \mathrm{C}$ under a nitrogen atmosphere. Afterwards, the mixture was diluted with $30 \mathrm{~mL}$ of ethyl acetate and washed with saturated aqueous $\mathrm{NH}_{4} \mathrm{Cl}(2 \times 10 \mathrm{~mL})$. The organic layer was dried over magnesium sulfate and evaporated in vacuo. This resulted in a yellow-orange powder $(0.0475 \mathrm{~g})$ which was dissolved in tetrahydrofuran and coated under reduced pressure onto silica. Subsequently, purification was performed via automated flash chromatography with hexane/ethyl acetate as eluent on a Reveleris ${ }^{\circledR} 12 \mathrm{~g}$ silica cartridge (1\% sample loading; flow rate: $30 \mathrm{~mL} \mathrm{~min}{ }^{-1}$; eluent: $2 \mathrm{CV}$ of $10 \%$ ethyl acetate, followed by a gradient from $10 \%$ to $70 \%$ ethyl acetate over $30 \mathrm{CV}$; detection wavelengths: $228 \mathrm{~nm}$ and $268 \mathrm{~nm})$. This resulted in (S)-4'benzyloxyblebbistatin $(S)-13(0.0242 \mathrm{~g}, 62 \%)$ as a yellow powder. The enantiomeric excess was $>99 \%$ as determined by chiral HPLC analysis analysis (Daicel Chiralpak IA column, acetonitrile/water (70:30), $1.0 \mathrm{~mL} \mathrm{~min}^{-1}, 25^{\circ} \mathrm{C}$ ). $R_{\mathrm{f}}=0.32$ (hexane/ethyl acetate, 3:2). Ee $>99 \%$, chiral HPLC: $t_{\mathrm{R}}((S)-\mathbf{1 3})=6.80 \mathrm{~min}, t_{\mathrm{R}}((R)-\mathbf{1 3})=9.55 \mathrm{~min}$ (Daicel Chiralpak IA column, acetonitrile/water (70:30), $\left.1.0 \mathrm{~mL} \mathrm{~min}^{-1}, 25^{\circ} \mathrm{C}\right) .{ }^{1} \mathrm{H}$ NMR (400 MHz, DMSO-d ${ }^{6}$ ): $\delta=2.21-2.28(2 \mathrm{H}, \mathrm{m}), 2.30(3 \mathrm{H}, \mathrm{s}), 3.87-3.95(1 \mathrm{H}, \mathrm{m}), 4.00-4.09(1 \mathrm{H}, \mathrm{m}), 5.13(2 \mathrm{H}, \mathrm{s}), 6.79$ $(1 \mathrm{H}, \mathrm{s}), 7.05-7.11(3 \mathrm{H}, \mathrm{m}), 7.31-7.38(2 \mathrm{H}, \mathrm{m}), 7.38-7.44(2 \mathrm{H}, \mathrm{m}), 7.45-7.49(2 \mathrm{H}, \mathrm{m}), 7.52$ $(1 \mathrm{H}, \mathrm{d}, J=1.6 \mathrm{~Hz}), 7.94-8.00(2 \mathrm{H}, \mathrm{m}) .{ }^{13} \mathrm{C} \mathrm{NMR}\left(100.6 \mathrm{MHz}, \mathrm{DMSO}-\mathrm{d}^{6}\right): \delta=20.7,29.0$, 
48.2, 69.8, 73.4, 115.3, 121.4, 121.7, 126.1, 126.8, 128.2, 128.3, 128.9, 132.2, 134.5, 136.9, 137.6, 150.0, 155.0, 165.3, 195.1. IR (ATR, $\left.\mathrm{cm}^{-1}\right): v_{\max }=733,1236,1481,1510,1597,1692$. MS (ESI): $\mathrm{m} / \mathrm{z}(\%)=399.2\left([\mathrm{M}+\mathrm{H}]^{+}, 100\right)$. HRMS (ESI): calculated for $\mathrm{C}_{25} \mathrm{H}_{23} \mathrm{~N}_{2} \mathrm{O}_{3}$ $\left([\mathrm{M}+\mathrm{H}]^{+}\right)$399.1703; found 399.1713. MW = 398.45. ${ }^{1} \mathrm{H}$ NMR spectrum, ${ }^{13} \mathrm{C}$ NMR spectrum and chiral HPLC chromatograms are provided in Figures S40-S41 and S64-S65 in the Supporting Information.

4.2.12. (S)-1-(4-aminophenyl)-3a-hydroxy-6-methyl-1,2,3,3a-tetrahydro-4H-pyrrolo[2,3$b]$ quinolin-4-one $((S)-31)[18]$

In each of seven vials of $3 \mathrm{~mL}, 5.0 \mathrm{mg}$ of $(S)-29$ (0.015 mmol, 1 equiv) was dissolved in $2 \mathrm{~mL}$ of methanol, after which $9.4 \mathrm{mg}$ of ammonium formate $(0.148 \mathrm{mmol}, 10$ equiv) and $5.0 \mathrm{mg}$ of $10 \% \mathrm{Pd} / \mathrm{C}$ were added. The mixture was stirred for 15 minutes at room temperature. Next, the contents of all seven vials were filtered off over celite and the filter cake was rinsed with $20 \mathrm{~mL}$ of methanol. Afterwards, the filtrate was concentrated to a volume of $5 \mathrm{~mL}$, diluted with $70 \mathrm{~mL}$ of ethyl acetate, washed with saturated aqueous $\mathrm{NH}_{4} \mathrm{Cl}(2 \times 30 \mathrm{~mL})$ and dried over magnesium sulfate. Evaporation in vacuo afforded a dark orange powder $(0.039 \mathrm{~g})$ which was dissolved in tetrahydrofuran and coated under reduced pressure onto silica. Subsequently, purification was performed via automated flash chromatography with hexane/ethyl acetate as eluent on a Reveleris ${ }^{\circledR} 12 \mathrm{~g}$ silica cartridge $\left(0.3 \%\right.$ sample loading; flow rate: $36 \mathrm{~mL} \mathrm{~min}{ }^{-1}$; eluent: $2 \mathrm{CV}$ of $20 \%$ ethyl acetate, followed by a gradient from $20 \%$ to $100 \%$ ethyl acetate over $20 \mathrm{CV}$; detection wavelengths: $246 \mathrm{~nm}$ and $260 \mathrm{~nm}$ ). This resulted in (S)-4'aminoblebbistatin $(S)-\mathbf{3 1}(9.8 \mathrm{mg}, 31 \%)$ as a bright red powder. $R_{\mathrm{f}}=0.25$ (hexane/ethyl acetate, 1:4). ${ }^{1} \mathrm{H}$ NMR (400 MHz, DMSO-d $\left.{ }^{6}\right): \delta=2.17-2.24(2 \mathrm{H}, \mathrm{m}), 2.28(3 \mathrm{H}, \mathrm{s}), 3.77-3.89$ $(1 \mathrm{H}, \mathrm{m}), 3.94-4.04(1 \mathrm{H}, \mathrm{m}), 6.71(1 \mathrm{H}, \mathrm{s}), 6.57-6.64(2 \mathrm{H}, \mathrm{m}), 7.01(1 \mathrm{H}, \mathrm{d}, J=8.2 \mathrm{~Hz}), 7.31$ $\left(1 \mathrm{H}, \mathrm{dd}, J_{1}=8.1 \mathrm{~Hz}, J_{2}=1.7 \mathrm{~Hz}\right), 7.48(1 \mathrm{H}, \mathrm{d}, J=1.7 \mathrm{~Hz}), 7.62-7.67(2 \mathrm{H}, \mathrm{m}) .{ }^{13} \mathrm{C} \mathrm{NMR}$ $\left(100.6 \mathrm{MHz}, \mathrm{DMSO}-\mathrm{d}^{6}\right): \delta=20.6,29.1,48.4,73.5,114.1,121.2,122.1,126.0,126.7,130.2$, 131.5, 136.9, 146.0, 150.7, 165.0, 195.3. IR (ATR, $\left.\mathrm{cm}^{-1}\right): v_{\max }=833,1263,1477,1508,1593$, 1674, 3347, 3445, 3499. MS (ESI): m/z (\%) = $308.0\left([\mathrm{M}+\mathrm{H}]^{+}, 100\right)$. HRMS (ESI): calculated for $\mathrm{C}_{18} \mathrm{H}_{18} \mathrm{~N}_{3} \mathrm{O}_{2}\left([\mathrm{M}+\mathrm{H}]^{+}\right)$308.1394; found 308.1390. $\mathrm{MW}=307.35$. ${ }^{1} \mathrm{H} \mathrm{NMR}$ and ${ }^{13} \mathrm{C} \mathrm{NMR}$ spectra are provided in Figures S42-S43 in the Supporting Information.

\subsection{ATPase assay}

\subsubsection{Preparation of F-actin filaments stock solution}


Pre-formed rabbit skeletal muscle F-actin filaments (cat. \# AKF99) were purchased from Cytoskeleton, Inc. in lyophilized form $(1 \mathrm{mg})$. The protein was dissolved in $2.4 \mathrm{~mL}$ of Milli-Q water and gently mixed to a concentration of $0.4 \mathrm{mg} \mathrm{mL}^{-1}$. To allow filaments to dissociate from each other, this solution was incubated at room temperature for 10 minutes. Then, the filaments were aliquoted into $100 \mu \mathrm{L}$ samples, snap frozen in liquid nitrogen and stored at $-80{ }^{\circ} \mathrm{C}$. For compounds $(S)-\mathbf{2 - 7},(S)-8-13$ and $(S)-\mathbf{2 9 , 3 1}$, different batches of pre-formed rabbit skeletal muscle F-actin filaments were used. As a reference, compound $(S)$-1 was evaluated with all batches of pre-formed rabbit skeletal muscle F-actin filaments.

\subsubsection{Preparation of myosin stock solution}

Full-length rabbit skeletal muscle myosin II protein (cat. \# MY02) was purchased from Cytoskeleton, Inc. in lyophilized form (1 mg). The protein was dissolved in $100 \mu \mathrm{L}$ of Milli-Q water containing $1 \mathrm{mM}$ DTT and incubated on ice for 5 minutes to completely solubilize it to a concentration of $10 \mathrm{mg} \mathrm{mL}^{-1}$. Care should be taken not to vortex the solution, in order to avoid protein denaturation caused by shear stress. Then, the myosin solution was further aliquoted into $10 \mu \mathrm{L}$ samples, snap frozen in liquid nitrogen and stored at $-80{ }^{\circ} \mathrm{C}$. For compounds $(S)$-2-7, $(S)-8-13$ and $(S)$-29,31, different batches of full-length rabbit skeletal muscle myosin II protein were used. As a reference, compound $(S)-\mathbf{1}$ was evaluated with all batches of full-length rabbit skeletal muscle myosin II protein.

\subsubsection{Preparation of ATP stock solution}

Adenosine 5'-triphosphate disodium salt (ATP, cat.\# BSA04) was purchased from Cytoskeleton, Inc. in lyophilized form ( $1 \mathrm{mg}$ ). The ATP was reconstituted to $100 \mathrm{mM}$ with $1 \mathrm{~mL}$ of ice-cold $100 \mathrm{mM}$ Tris- $\mathrm{HCl} \mathrm{pH} 7.5$ and then aliquoted into $10 \mu \mathrm{L}$ samples, snap frozen in liquid nitrogen and stored at $-20{ }^{\circ} \mathrm{C}$. For compounds $(S)-\mathbf{2 - 7},(S)-\mathbf{8}-\mathbf{1 3}$ and $(S)$ 29,31, different batches of adenosine 5'-triphosphate disodium salt were used. As a reference, compound $(S)-1$ was evaluated with all batches of adenosine 5'-triphosphate disodium salt.

\subsubsection{ATPase assay}

Screening for inhibitors of rabbit skeletal muscle myosin II ATPase was performed in an ATPase end-point assay adapted from the method of Kodama et al. [48]. Incubation times and relative amounts of F-actin, myosin and ATP were determined based on a publication of Cheung et al. [49]. As the linear range for inorganic phosphate detection of the assay extends 
from approximately $0.1 \mathrm{nmol}$ to $1.5 \mathrm{nmol}$ of inorganic phosphate, a total amount of $1.6 \mathrm{nmol}$ ATP was used [50].

Prior to each assay, aliquoted samples of F-actin, myosin and ATP were defrosted rapidly in a $37{ }^{\circ} \mathrm{C}$ water bath and further dilutions were made: myosin was diluted to $33 \mu \mathrm{g} \mathrm{mL}^{-1}$ with icecold reaction buffer (15 mM Tris- $\mathrm{HCl} \mathrm{pH} 7.5,25 \mathrm{mM} \mathrm{KCl}, 10 \mathrm{mM} \mathrm{MgCl}_{2}, 0.1 \mathrm{mM}$ EGTA) and stored on ice, ATP was diluted to $0.04 \mathrm{mM}$ with ice-cold $15 \mathrm{mM}$ Tris- $\mathrm{HCl} \mathrm{pH} 7.5$ and stored on ice, F-actin was diluted to $133 \mu \mathrm{g} \mathrm{mL}^{-1}$ with reaction buffer and stored at room temperature.

Chemical compounds dissolved in DMSO $(1 \mu \mathrm{L})$ were transferred into each well of a 96-well plate. Then, $15 \mu \mathrm{L}$ of reaction buffer, $15 \mu \mathrm{L}$ of $133 \mu \mathrm{g} \mathrm{mL}{ }^{-1}$ F-actin and $15 \mu \mathrm{L}$ of $33 \mu \mathrm{g} \mathrm{mL} \mathrm{L}^{-1}$ myosin were subsequently distributed in each well using a multichannel pipette. Afterwards, the ATP hydrolysis reaction was initiated by adding $15 \mu \mathrm{L}$ of $0.04 \mathrm{mM}$ ATP per well using a multichannel pipette and was then incubated for 1 hour at $37^{\circ} \mathrm{C}$. To measure the amount of inorganic phosphate $\left(\mathrm{P}_{i}\right)$ generated during the enzymatic hydrolysis of ATP, $139 \mu \mathrm{L}$ of development solution (CytoPhos ${ }^{\mathrm{TM}}$ reagent, cat. \# BK054 from Cytoskeleton) was added to each well using a multichannel pipette. After 20 minutes, the absorbance at $650 \mathrm{~nm}$ was measured in each assay well using a SpectraMax ${ }^{\circledR}$ Paradigm $^{\circledR}$ Multi-Mode Microplate Reader. On each assay plate, two concentrations of $(S)-\mathbf{1}(2.25 \mu \mathrm{M}$ or $1 \mu \mathrm{M}$ for $(S)-\mathbf{2 - 7}$ and $(S)-8$ $\mathbf{1 3 , 2 9 , 3 1}$, respectively, and $32.5 \mu \mathrm{M}$ ) were included as a positive control and the resulting amount of inhibition was comparable over the different assay plates. All screenings were carried out twice $(\mathrm{N}=2)$.

\subsection{5. $\mathrm{IC}_{50}$ determination}

Data points representing the mean \pm s.d. of at least three samples, were plotted on semi-log axes and a 4-parameter logistic curve, based on the following equation, was fitted to the means.

$$
\mathrm{y}=\mathrm{A}+\frac{\mathrm{B}-\mathrm{A}}{1+\left(\frac{\mathrm{x}}{\mathrm{C}}\right)^{\mathrm{D}}}
$$

Here, y represents the actin-activated ATPase activity of rabbit skeletal muscle myosin II (\%) and $\mathrm{x}$ corresponds to the compound concentration $(\mu \mathrm{M})$. $\mathrm{A}$ is the ATPase activity corresponding to the asymptote at high compound concentrations (\%), B is the ATPase activity corresponding to the asymptote at low compound concentrations (\%), $\mathrm{C}$ represents the compound concentration corresponding to the midpoint between $\mathrm{A}$ and $\mathrm{B}(\mu \mathrm{M})$ (i.e. $\mathrm{IC}_{50}$ 
value) and $\mathrm{D}$ describes how rapidly the curve makes its transition from the asymptotes in the center of the curve.

\subsection{Determination of photostability}

\subsubsection{W Xenon Lamp light source}

$(S)$-blebbistatin $(S)$-1 was dissolved in methanol and further diluted with phosphate-buffered saline (PBS) to obtain a final concentration of $20 \mu \mathrm{M}$. The amount of methanol was maintained at a constant concentration of $2.67 \%(\mathrm{v} / \mathrm{v})$ in all samples. A different sample was used for each irradiation time. Irradiation at $488 \mathrm{~nm}$ (excitation slit width $=10 \mathrm{~nm}$ ) was performed using an Edingburgh Instruments F900 Fluorescence Spectrometer equipped with a $450 \mathrm{~W}$ Xenon Lamp. Afterwards, UV-VIS absorption spectra were recorded for all samples using a Varian Cary 50 spectrophotometer. All absorption spectra were corrected for the solvent mixture by subtracting the absorption spectrum of the solvent blank.

\subsubsection{TL 140W/03 light source}

Stock solutions of chemical compounds were prepared in DMSO (Figure 4B, Figure S3), DMSO/ $\mathrm{H}_{2} \mathrm{O}(1: 1)$ (Figures 4B-C, Figure S3, Figure S4) or a 1:1 mixture of DMSO and DMEM supplemented with 20\% (v/v) fetal calf serum (Figure 4D, Figure 5). Then, $200 \mu \mathrm{L}$ of each stock solution was transferred into the wells of 96-well plates. Separate wells were used for different irradiation times, so each well corresponded to one compound and one irradiation time. The solutions were irradiated for 0-90 min by placing the 96-well plates (covered with an evaporation lid) on top of two luminescent tubes (TL 140W/03, Philips, Special Lighting, Belgium) emitting 390-470 nm with a maximum at $420 \mathrm{~nm}$, using holders of $6 \mathrm{~cm}$ height (Figures S2 in the Supporting Information). On each 96-well plate, two columns could be irradiated with one luminescent tube. After the appropriate illumination time, $200 \mu \mathrm{L}$ (i.e. the total content) of each well was analyzed by HPLC as such: the absolute peak area of the compound under study was quantified and compared with that at the start of the experiment. The relative amount of compound (\%) was plotted in function of irradiation time (min) on semi-log axes and a 4-parameter logistic curve, based on the following equation, was fitted to the data points.

$$
y=A+\frac{B-A}{1+\left(\frac{x}{C}\right)^{D}}
$$


Here, $y$ represents the relative amount of compound (\%) and $\mathrm{x}$ corresponds to the irradiation time (min). A is the relative amount of compound corresponding to the asymptote at high irradiation times (\%), B is the relative amount of compound corresponding to the asymptote at low irradiation times (\%), $\mathrm{C}$ represents the irradiation time corresponding to the midpoint between $\mathrm{A}$ and $\mathrm{B}(\mathrm{min})$ and $\mathrm{D}$ describes how rapidly the curve makes its transition from the asymptotes in the center of the curve. Finally, the compound half-life (min) was determined by solving the equation above for $\mathrm{y}=50 \%$.

\subsection{Determination of steady-state aqueous solubility}

The steady-state aqueous solubility was determined by Eurofins Panlabs.

Compounds were added to a PBS pH 7.4 buffer as a $10 \mathrm{mM}$ dimethyl sulfoxide (DMSO) solution and were incubated at room temperature while agitating the suspension. DMSO and compound concentrations were $2 \%(\mathrm{v} / \mathrm{v})$ and $200 \mu \mathrm{M}$, respectively. After 24 hours, the suspension was centrifuged and filtered through a $0.2 \mu \mathrm{M}$ filter membrane. Compound concentrations in the buffer sample were determined by HPLC. Absorption spectra $(230 \mathrm{~nm})$ were recorded and the concentration of the dissolved compound was determined by comparing the peak area of the principal peak in the buffer sample with the peak area of the corresponding peak in a calibration standard $(200 \mu \mathrm{M})$ containing organic solvent (methanol/water (60:40)). The experiments were performed in duplicate.

\subsection{Determination of Caco-2 cell membrane permeability}

Caco-2 cell membrane permeability was determined by Eurofins Panlabs.

In short, Caco-2 cells were cultured on 96-well polycarbonate membrane filters and the apparent permeability $\left(\mathrm{P}_{\mathrm{app}}\right)$ of test compounds were determined in the apical-to-basolateral (A-B) and basolateral-to-apical (B-A) directions across the Caco-2 cell monolayer. Compounds were prepared at $10 \mu \mathrm{M}$ in HBSS-HEPES buffer, $\mathrm{pH} 7.4$ (with a final DMSO concentration of $1 \%(\mathrm{v} / \mathrm{v})$ ) and added to the apical side (for A-B permeability) or basolateral side (for B-A permeability). The same buffer without compound was added to the basolateral side (for A-B permeability) or apical side (for B-A permeability). The assay plates were incubated at $37^{\circ} \mathrm{C}$ with gentle shaking for 60 minutes (for A-B permeability) or 40 minutes (for B-A permeability). Samples were taken from the donor side at the start and from the donor and receiver sides at the end of the incubation and analyzed by HPLC-MS/MS. The 
apparent permeability $\left(\mathrm{P}_{\mathrm{app}}\right)$ was calculated based on the appearance rate of compound in the receiver side. In addition, recovery of the test compound was determined as the relative amount of compound detected in both the receiver and the donor sides at the end of the assay to the amount detected in the donor side at the start. The experiments were performed in duplicate.

\section{Acknowledgement}

This work was supported by the Ghent University (BOF).

\section{References}

[1] H.L. Sweeney, A. Houdusse, Structural and functional insights into the myosin motor mechanism, Annu. Rev. Biophys. 39 (2010) 539-557.

[2] L.M. Coluccio, Myosins: a superfamily of molecular motors. Springer, Netherlands, 2008 .

[3] M.J. Lehmann, N.M. Sherer, C.B. Marks, M. Pypaert, W. Mothes, Actin- and myosindriven movement of viruses along filopodia precedes their entry into cells, J. Cell Biol. 170 (2005) 317-325.

[4] M. Kumakura, A. Kawaguchi, K. Nagata, Actin-myosin network is required for proper assembly of influenza virus particles, Virology 476 (2015) 141-150.

[5] K. Chang, J. Baginski, S.F. Hassan, M. Volin, D. Shukla, V. Tiwari, Filopodia and viruses: an analysis of membrane processes in entry mechanisms, Front. Microbiol. 7 (2016)

[6] J. Gao, S. Xiao, Y. Xiao, X. Wang, C. Zhang, Q. Zhao, Y. Nan, B. Huang, H. Liu, N. Liu, J. Lv, T. Du, Y. Sun, Y. Mu, G. Wang, S.F. Syed, G. Zhang, J.A. Hiscox, I. Goodfellow, E.-M. Zhou, MYH9 is an essential factor for porcine reproductive and respiratory syndrome virus infection, Sci. Rep. 6 (2016) 25120.

[7] M. Lum, R. Morona, Myosin IIA is essential for Shigella flexneri cell-to-cell spread, Pathog. Dis. 72 (2014) 174-187.

[8] M.S. Duxbury, S.W. Ashley, E.E. Whang, Inhibition of pancreatic adenocarcinoma cellular invasiveness by blebbistatin: a novel myosin II inhibitor, Biochem. Biophys. Res. Commun. 313 (2004) 992-997.

[9] V. Betapudi, L.S. Licate, T.T. Egelhoff, Distinct roles of nonmuscle myosin II isoforms in the regulation of MDA-MB-231 breast cancer cell spreading and migration, Cancer Res. 66 (2006) 4725-4733.

[10] C. Beadle, M.C. Assanah, P. Monzo, R. Vallee, S.S. Rosenfeld, P. Canoll, The role of myosin II in glioma invasion of the brain, Mol. Biol. Cell 19 (2008) 3357-3368. 
[11] X. Tang, T.B. Kuhlenschmidt, J. Zhou, P. Bell, F. Wang, M.S. Kuhlenschmidt, T.A. Saif, Mechanical force affects expression of an in vitro metastasis-like phenotype in HCT-8 Cells, Biophys. J. 99 (2010) 2460-2469.

[12] L. Derycke, C. Stove, A.-S. Vercoutter-Edouart, O. De Wever, L. Dollé, N. Colpaert, H. Depypere, J.-C. Michalski, M. Bracke, The role of non-muscle myosin IIA in aggregation and invasion of human MCF-7 breast cancer cells, Int. J. Dev. Biol. 55 (2011) 835-840.

[13] J.H. Kim, R.S. Adelstein, LPA1-induced migration requires nonmuscle myosin II light chain phosphorylation in breast cancer cells, J. Cell. Physiol. 226 (2011) 2881-2893.

[14] S. Ivkovic, C. Beadle, S. Noticewala, S.C. Massey, K.R. Swanson, L.N. Toro, A.R. Bresnick, P. Canoll, S.S. Rosenfeld, Direct inhibition of myosin II effectively blocks glioma invasion in the presence of multiple motogens, Mol. Biol. Cell 23 (2012) 533-542.

[15] J. Limouze, A.F. Straight, T. Mitchison, J.R. Sellers, Specificity of blebbistatin, an inhibitor of myosin II, J. Muscle Res. Cell M. 25 (2004) 337-341.

[16] C. Lucas-Lopez, S. Patterson, T. Blum, A.F. Straight, J. Toth, A.M.Z. Slawin, T.J. Mitchison, J.R. Sellers, N.J. Westwood, Absolute stereochemical assignment and fluorescence tuning of the small molecule tool, (-)-blebbistatin, Eur. J. Org. Chem. (2005) 1736-1740.

[17] M. Képiró, B.H. Várkuti, L. Végner, G. Vörös, G. Hegyi, M. Varga, A. MálnásiCsizmadia, para-Nitroblebbistatin, the non-cytotoxic and photostable myosin II inhibitor, Angew. Chem., Int. Ed. 53 (2014) 8211-8215.

[18] B.H. Várkuti, M. Képiró, I.Á. Horváth, L. Végner, S. Ráti, Á. Zsigmond, G. Hegyi, Z. Lenkei, M. Varga, A. Málnási-Csizmadia, A highly soluble, non-phototoxic, non-fluorescent blebbistatin derivative, Sci. Rep. 6 (2016) 26141.

[19] S. Verhasselt, B.I. Roman, O. De Wever, K. Van Hecke, R. Van Deun, M. Bracke, C.V. Stevens, Discovery of (S)-3'-hydroxyblebbistatin and (S)-3'-aminoblebbistatin: polar myosin II inhibitors with superior research tool properties, Org. Biomol. Chem. 15 (2017) 2104-2118.

[20] M. Képiró, B.H. Várkuti, A. Bodor, G. Hegyi, L. Drahos, M. Kovács, A. MálnásiCsizmadia, Azidoblebbistatin, a photoreactive myosin inhibitor, Proc. Natl. Acad. Sci. U. S. A. 109 (2012) 9402-9407.

[21] C. Lucas-Lopez, J.S. Allingham, T. Lebl, C.P.A.T. Lawson, R. Brenk, J.R. Sellers, I. Rayment, N.J. Westwood, The small molecule tool (S)-(-)-blebbistatin: novel insights of relevance to myosin inhibitor design, Org. Biomol. Chem. 6 (2008) 2076-2084.

[22] J.S. Allingham, R. Smith, I. Rayment, The structural basis of blebbistatin inhibition and specificity for myosin II, Nat. Struct. Mol. Biol. 12 (2005) 378-379.

[23] F. Jahani, M. Tajbakhsh, H. Golchoubian, S. Khaksar, Guanidine hydrochloride as an organocatalyst for N-Boc protection of amino groups, Tetrahedron Lett. 52 (2011) 1260-1264. 
[24] Z. Jian, M.C. Baier, S. Mecking, Suppression of chain transfer in catalytic acrylate polymerization via rapid and selective secondary insertion, J. Am. Chem. Soc. 137 (2015) 2836-2839.

[25] D.L. Reger, T.C. Grattan, K.J. Brown, C.A. Little, J.J.S. Lamba, A.L. Rheingold, R.D. Sommer, Syntheses of tris(pyrazolyl)methane ligands and $\left\{[\right.$ tris(pyrazolyl)methane $\left.] \mathrm{Mn}(\mathrm{CO})_{3}\right\} \mathrm{SO}_{3} \mathrm{CF}_{3}$ complexes: comparison of ligand donor properties, J. Organomet. Chem. 607 (2000) 120-128.

[26] E. Haldón, E. Álvarez, M.C. Nicasio, P.J. Pérez, Copper(I) complexes with trispyrazolylmethane ligands: synthesis, characterization, and catalytic activity in crosscoupling reactions, Inorg. Chem. 51 (2012) 8298-8306.

[27] In general, amidation reactions of aryl bromides often fail in the presence of $\mathrm{K}_{3} \mathrm{PO}_{4}$. So, in those cases $\mathrm{K}_{3} \mathrm{PO}_{4}$ is generally replaced with a weaker base such as $\mathrm{K}_{2} \mathrm{CO}_{3}$ [28].

[28] A. Klapars, X. Huang, S.L. Buchwald, A general and efficient copper catalyst for the amidation of aryl halides, J. Am. Chem. Soc. 124 (2002) 7421-7428.

[29] T. Myochin, K. Hanaoka, S. Iwaki, T. Ueno, T. Komatsu, T. Terai, T. Nagano, Y. Urano, Development of a series of near-infrared dark quenchers based on Si-rhodamines and their application to fluorescent probes, J. Am. Chem. Soc. 137 (2015) 4759-4765.

[30] B. Alcaide, P. Almendros, J.M. Alonso, Ruthenium-catalyzed chemoselective N-allyl cleavage: novel Grubbs carbene mediated deprotection of allylic amines, Chem. Eur. J. 9 (2003) 5793-5799.

[31] D.H. Brown Ripin, M. Vetelino, 2-Methyltetrahydrofuran as an alternative to dichloromethane in 2-phase reactions, Synlett 15 (2003) 2353-2353.

[32] J. Kolega, Phototoxicity and photoinactivation of blebbistatin in UV and visible light, Biochem. Biophys. Res. Commun. 320 (2004) 1020-1025.

[33] B. Ramamurthy, C.M. Yengo, A.F. Straight, T.J. Mitchison, H.L. Sweeney, Kinetic mechanism of blebbistatin inhibition of nonmuscle myosin IIB, Biochemistry 43 (2004) 14832-14839.

[34] T. Sakamoto, J. Limouze, C.A. Combs, A.F. Straight, J.R. Sellers, Blebbistatin, a myosin II inhibitor, is photoinactivated by blue light, Biochemistry 44 (2005) 584-588.

[35] A. Mikulich, S. Kavaliauskiene, P. Juzenas, Blebbistatin, a myosin inhibitor, is phototoxic to human cancer cells under exposure to blue light, Biochim. Biophys. Acta, Gen. Subj. 1820 (2012) 870-877.

[36] M. Schuppler, F.C. Keber, M. Kröger, A.R. Bausch, Boundaries steer the contraction of active gels, Nat. Commun. 7 (2016) 13120.

[37] R. Bzymek, M. Horsthemke, K. Isfort, S. Mohr, K. Tjaden, C. Müller-Tidow, M. Thomann, T. Schwerdtle, M. Bähler, A. Schwab, P.J. Hanley, Real-time two- and threedimensional imaging of monocyte motility and navigation on planar surfaces and in collagen matrices: roles of Rho, Sci. Rep. 6 (2016) 25016. 
[38] V.V. Fedorov, I.T. Lozinsky, E.A. Sosunov, E.P. Anyukhovsky, M.R. Rosen, C.W. Balke, I.R. Efimov, Application of blebbistatin as an excitation-contraction uncoupler for electrophysiologic study of rat and rabbit hearts, Heart Rhythm 4 (2007) 619-626.

[39] K. Wong, A. Van Keymeulen, H.R. Bourne, PDZRhoGEF and myosin II localize RhoA activity to the back of polarizing neutrophil-like cells, J. Cell Biol. 179 (2007) 11411148 .

[40] L.M. Swift, H. Asfour, N.G. Posnack, A. Arutunyan, M.W. Kay, N. Sarvazyan, Properties of blebbistatin for cardiac optical mapping and other imaging applications, Pflugers Arch. Eur. J. Physiol. 464 (2012) 503-512.

[41] For completeness, stability curves obtained in $\mathrm{DMSO} / \mathrm{H}_{2} \mathrm{O}(1: 1)$ are provided in the Supporting Information.

[42] Molecular Operating Environment (MOE), 2016.08, Chemical Computing Group Inc., 1010 Sherbooke St. West, Suite \#910, Montreal, QC, Canada, H3A 2R7 (2017).

[43] J.W. Tye, Z. Weng, A.M. Johns, C.D. Incarvito, J.F. Hartwig, Copper complexes of anionic nitrogen ligands in the amidation and imidation of aryl halides, J. Am. Chem. Soc. 130 (2008) 9971-9983.

[44] M. Sedlák, L. Hejtmánková, P. Kašparová, J. Kaválek, Kinetics and mechanism of formation and decomposition of substituted 1-phenylpyrrolidin-2-ones in basic medium, J. Phys. Org. Chem. 15 (2002) 165-173.

[45] J.-d.A.K. Twibanire, H. Al-Mughaid, T.B. Grindley, Synthesis of new cores and their use in the preparation of polyester dendrimers, Tetrahedron 66 (2010) 9602-9609.

[46] M. Reggelin, B. Junker, T. Heinrich, S. Slavik, P. Bühle, Asymmetric synthesis of highly substituted azapolycyclic compounds via 2-alkenyl sulfoximines: potential scaffolds for peptide mimetics, J. Am. Chem. Soc. 128 (2006) 4023-4034.

[47] D.R. Vutukuri, P. Bharathi, Z. Yu, K. Rajasekaran, M.-H. Tran, S. Thayumanavan, A mild deprotection strategy for allyl-protecting groups and its implications in sequence specific dendrimer synthesis, J. Org. Chem. 68 (2003) 1146-1149.

[48] T. Kodama, K. Fukui, K. Kometani, The initial phosphate burst in ATP hydrolysis by myosin and subfragment-1 as studied by a modified malachite green method for determination of inorganic phosphate, J. Biochem. 99 (1986) 1465-1472.

[49] A. Cheung, J.A. Dantzig, S. Hollingworth, S.M. Baylor, Y.E. Goldman, T.J. Mitchison, A.F. Straight, A small-molecule inhibitor of skeletal muscle myosin II, Nat. Cell Biol. 4 (2002) 83-88.

[50] The $0.4 \mathrm{mg} \mathrm{mL}^{-1}$ solution of pre-formed rabbit skeletal muscle F-actin filaments (cat. \# AKF99) from Cytoskeleton, Inc. already contains 0.2 mM ATP. 